\title{
MODELO PARA ESTIMATIVA dO VOLUME MÁXIMO DE CALDA VISANDO A APLICAÇÃO FOLIAR DE PRODUTOS QUÍMICOS NA \\ CULTURA DE MILHO (Zea mays L.)
}

\section{MARIA del VALLE BASANTA \\ Engenheira Agrônoma}

Orientador: Prof. Dr. Durval Dourado-Neto

\begin{abstract}
Dissertação apresentada à Escola Superior de Agricultura "Luiz de Queiroz", Universidade de São Paulo, para a obtenção do título de Mestre em Agronomia, Área de Concentração: Fitotecnia.
\end{abstract}

P I R A C I C A B A

Estado de São Paulo - Brasil Julho - 1999 


\section{Dados Internacionais de Catalogação na Publicação (CIP) DIVISĀO DE BIBLIOTECA E DOCUMENTAÇĀO - Campus "Luiz de Queiroz"/USP}

Basanta, Maria del Valle Modelo para estimativa do volume máximo de calda visando a aplicação foliar de produtos quimicos na cultura de milho (Zea mays L.) / Maria del Valle Basanta. - Piracicaba, 1999. $65 \mathrm{p}$.

Dissertação (mestrado) - Escola Superior de Agricultura Luiz de Queiroz, 1999. Bibliografia.

1. Efeito da temperatura 2. Folha 3. Milho hiđrido 4. Modelo matemático 5. População de planta 6. Quimigação I. Título

CDD 633.15 


\section{ERRATA}

\begin{tabular}{|c|c|c|}
\hline Onde se lê & Lê-se & Pág \\
\hline ..."radical"... & ..."radicular"... & 6 \\
\hline ...", tal como é detalhado na Figura $1 . " . .$. & ...", tal como é detalhado na Figura 3.”... & 11 \\
\hline ..."cumprimento"... & ..."comprimento"... & 11 \\
\hline$Y_{i j k}=\mu+t_{i}+l_{j}+e_{i j}+a_{k}+(t a)_{i k}+(l a)_{j k}+(t l a)_{i j k}+e_{i j k k}$ & $\mathrm{Y}_{\mathrm{ijk \textrm {k }}}=\mu+\mathrm{t}_{\mathrm{i}}+\mathrm{L}_{\mathrm{l}}+(\mathrm{tL})_{\mathrm{il}}+\mathrm{e}_{\mathrm{ilj}}+\mathrm{a}_{\mathrm{k}}+(\mathrm{ta})_{\mathrm{ikk}}+(\mathrm{la})_{h \mathrm{k}}+(\mathrm{tla})_{\mathrm{llk}}+\mathrm{e}_{\mathrm{ijk \textrm {j }}}$ & 14 \\
\hline ..."I"... & ..."l"... & 15 \\
\hline$V_{w}=\left(\frac{m_{t}}{\rho_{w}}\right)-\left(\frac{m_{s}}{\rho_{w}}\right)\left[\frac{(2 U-1)}{(1-U)}\right]$ & $V_{w}=\frac{m_{t}}{\rho_{w}}-\frac{m_{s}}{\rho_{w}}\left[\frac{1}{(1-U)}\right]$ & 20 \\
\hline .."3048,00 mm"... & $\ldots " 304,8 \mathrm{~mm} " \ldots$ & 23 \\
\hline ..."34,50 трm"... & ..."3450 грm"... & 23 \\
\hline ..."uma maior lâmina"... & ..."um maior volume"... & 31 \\
\hline ..."0,999"... & $\ldots " 0,999 * * " .$. & 37 \\
\hline $\begin{array}{l}\text {..."equação para estimar a lâmina retida em função da população } \\
\text { e do desenvolvimento relativo"... }\end{array}$ & ..."equação para estimar a lâmina retida em função do desenvolvimento relativo"... & 38 \\
\hline
\end{tabular}


Aos meus pais,

Inés Dolores Castro de Basanta e

Enrique Daniel Basanta,

e a meu esposo,

Jorge Omar Gieco,

OFEREÇO

Aos argentinos da minha geração

que morreram na absurda guerra de Malvinas.

DEDICO 


\section{AGRADECIMENTO}

- A Deus pela sua permanente presença, especialmente nos momentos dificeis.

- A meus pais pela compreensão e apoio nesta e em todas as etapas da minha vida.

- Ao meu esposo Jorge Omar Gieco pela sua permanente companhia, amor, estímulo e colaboração.

- Ao Prof. Dr. Durval Dourado-Neto, pela orientação, pela amizade, pela permanente colaboração e apoio na realização deste trabalho e pela sua inestimável contribuição a minha formação profissional.

- Aos colegas e amigos, Engenheiros Agrônomos Graciela E. Cordone e Fernando Martínez pelo seu apoio e estímulo incondicional em todos os momentos.

- À Fundação de Amparo à pesquisa do Estado de São Paulo (FAPESP), pela bolsa de estudo fornecida e pelo apoio financeiro na realização deste trabalho.

- Aos Engenheiros Agrônomos e colegas Dálcio Ricardo Botelho Alves e Fátima Conceição Rezende pela valiosa colaboração prestada durante a fase experimental deste trabalho.

- Ao Engenheiro Florestal Cristian Andrés Carranza pela sua valiosa colaboração na definição do desenho experimental e na realização das análises estatísticas.

- Aos Engenheiros Agrônomos e colegas Ramiro López Ovejero pela colaboração prestada na fase experimental, e Axel García y García pela importante colaboração prestada na fase de redação deste trabalho.

- Aos funcionários do Departamento de Produção Vegetal pela sua colaboração na fase experimental, sem a qual este trabalho não poderia ter sido realizado. 


\section{SUMÁRIO}

Página

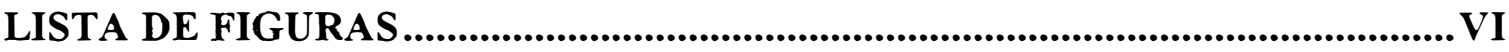

LISTA DE TABELAS ..........................................................................................

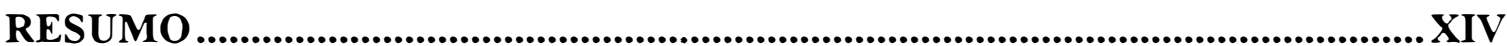

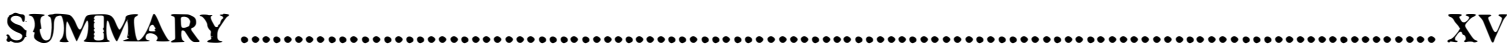

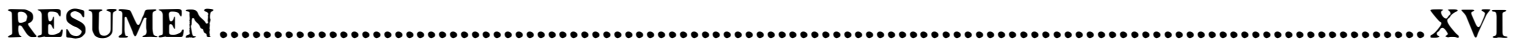

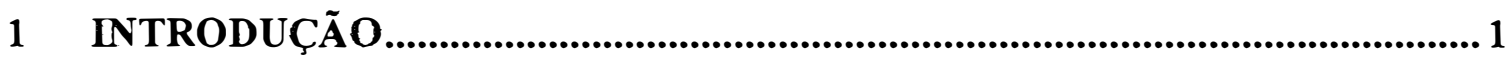

2 REVISÃO DE LITERATURA .................................................................. 3

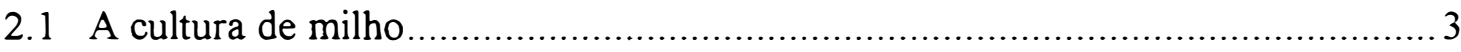

2.1.1 Importância do milho...................................................................... 3

2.1.2 Fenologia do milho .................................................................. 4

2.2 A quimigação e a irrigação por aspersão via pivô central ............................... 5

2.3 Fertirrigação, fungigação, herbigação e insetigação ...................................... 6

2.4 Efeito da cultura na distribuição de água .................................................. 7

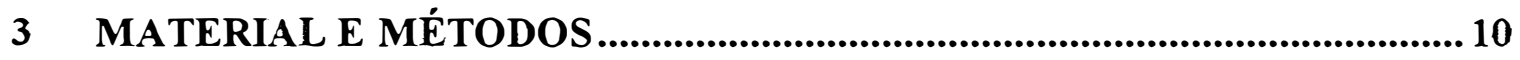

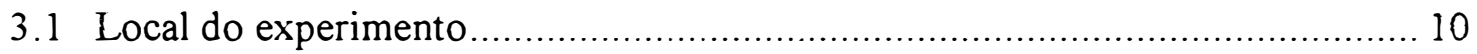

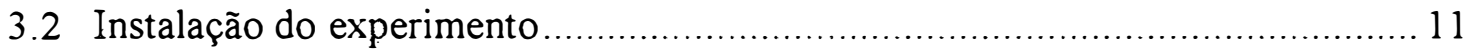

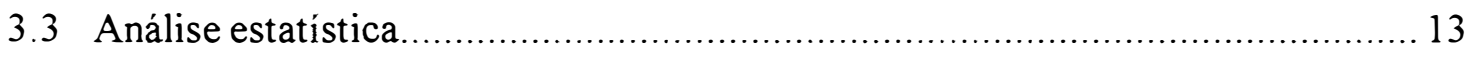

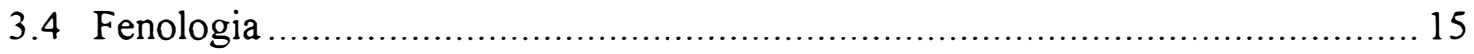

3.5 Desenvolvimento relativo da cultura .............................................. 15

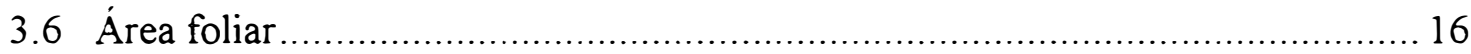

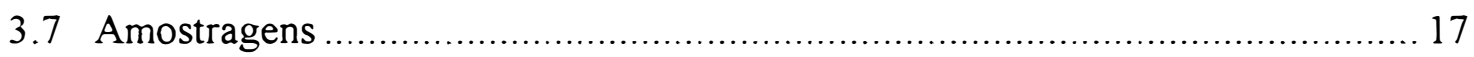

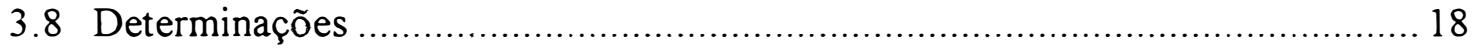

3.8.1 Determinação da lâmina de irrigação .......................................... 18 
3.8.2 Determinação da quantidade de água retida nas folhas ............................ 18

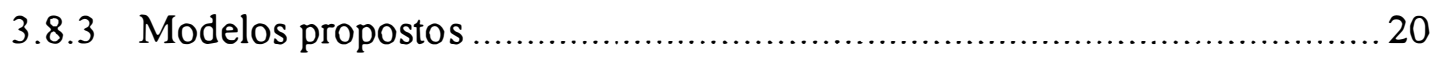

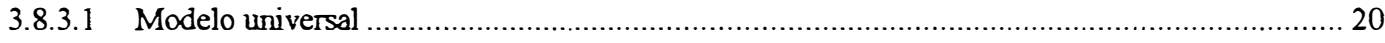

3.8.3.2 Modelo estatístico ............................................................................................ 22

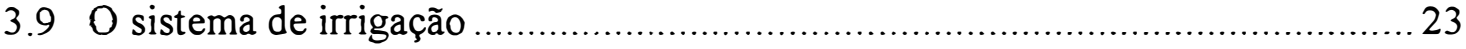

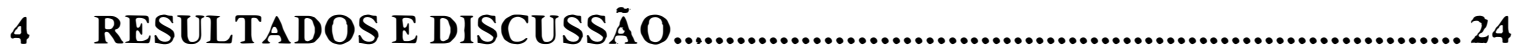

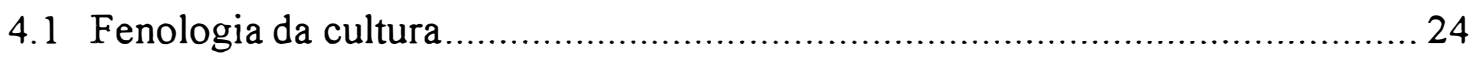

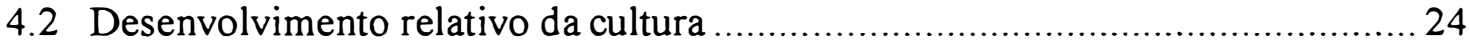

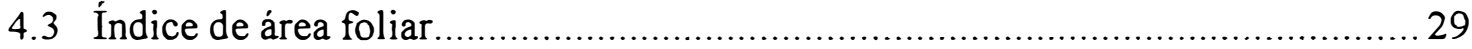

4.3.1 Análise de variância para os dois experimentos ....................................... 29

4.3.2 Modelo matemático para estimativa do índice de área foliar .................... 30

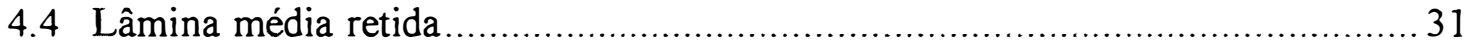

4.4.1 Análise de variância para os dois experimentos ....................................... 31

4.4.2 Modelo matemático para estimativa da lâmina média retida...................... 32

4.5 Volume de água retido por hectare na cultura de milho.................................... 34

4.5.1 Análise de variância para os dois experimentos ........................................ 34

4.5.2 Modelo matemático para estimativa do volume retido nas folhas das plantas

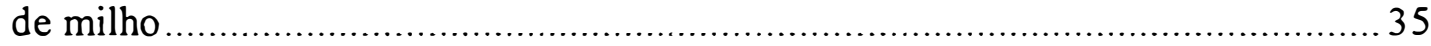

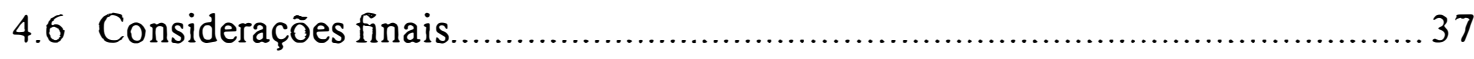

5 CONCLUSÕES

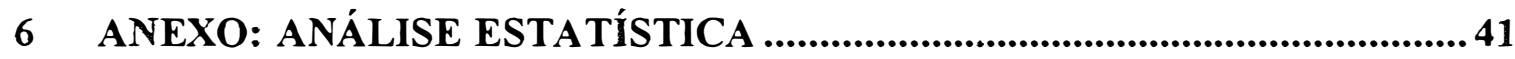

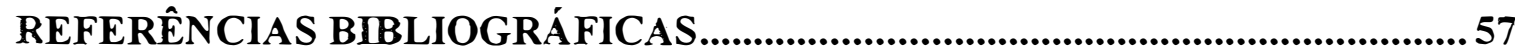

APÊNDICE: VALORES OBSERVADOS E ESTIMADOS DE ÍNDICE DE ÁREA FOLIAR (IAF, $M^{2} / M^{2}$ ), LÂMINA DE ÁGUA RETIDA (H, MM) E VOLUME MÁXIMO RETIDO DE ÁGUA (VR, L/HA) PELOS DIFERENTES MODELOS 62 


\section{LISTA DE FIGURAS}

Página

Figura 1. Disposição do conjunto experimental sob o pivô central da área experimental do Departamento de Produção Vegetal da ESALQ, Universidade de São Paulo. Piracicaba, SP.

Figura 2. Relação das parcelas com os aspersores e os coletores utilizados no teste de avaliação do pivô central.

Figura 3. Representação esquemática da área experimental ilustrando a distribuição espacial das parcelas referentes aos três níveis (Pl: 41.176, P2: 52.941 e P3: 64.706 plantas/ha) do ratamento (população) nos experimentos L1 (lâmina de irrigação: 3,6 mm) e L2 (lâmina de irrigação: $1,3 \mathrm{~mm}$ ).

Figura 4. Desenho esquemático de uma parcela experimental. 13

Figura 5. Disposição radial dos coletores sob o pivô para realização do teste de uniformidade de lâmina.

Figura 6. Fluxograma referente ao procedimento de estimativa do volume máximo de calda $(\mathrm{Vr}, 1 / \mathrm{ha})$ retido na folhagem da cultura de milho. $\mathrm{Tmin}_{\mathrm{i}}, \mathrm{T}_{\max _{\mathrm{i}}}$ e $\mathrm{T}_{\mathrm{i}}$ se referem às temperaturas $\left({ }^{\circ} \mathrm{C}\right)$ mínima, máxima e média do ar, respectivamente; Tb e $\mathrm{Tm}$ às temperaturas $\left({ }^{\circ} \mathrm{C}\right)$ basais inferior e superior da cultura, respectivamente; $\mathrm{P}$ à população $\left(\mathrm{pl} / \mathrm{m}^{2}\right)$, Par aos parâmetros empíricos dos diferentes modelos, $\mathrm{Dr}$ ao desenvolvimento relativo da cultura, h à lâmina $(\mathrm{mm})$ de água retida $\mathrm{e}$ IAF ao índice de área foliar $\left(\mathrm{m}^{2} / \mathrm{m}^{2}\right)$.

Figura 7. Índice de área foliar (IAF, $\mathrm{m}^{2} / \mathrm{m}^{2}$ ) em função da população de plantas $\left(\mathrm{P}, \mathrm{pl} / \mathrm{m}^{2}\right)$ e do desenvolvimento relativo da cultura (Dr) (Tabela 10).

Figura 8. Lâmina retida ( $h, \mathrm{~mm})$ em função do índice de área foliar $\left(\mathrm{IAF}, \mathrm{m}^{2} / \mathrm{m}^{2}\right)$ (Tabela 11).

Figura 9. Lâmina retida $(\mathrm{h}, \mathrm{mm})$ em função do desenvolvimento relativo da cultura (Dr) (Tabela 11) 
Figura 10. Volume médio retido $(\mathrm{Vr}, 1 / \mathrm{ha})$ em função da população de plantas $(\mathrm{P}$, $\mathrm{pl} / \mathrm{m}^{2}$ ) e do desenvolvimento relativo da cultura (Dr) (Tabela 12) (referência: planejamento).

Figura 11. Volume médio retido ( $\mathrm{Vr}, 1 / \mathrm{ha})$ em função do índice de área foliar (IAF, $\mathrm{m}^{2} / \mathrm{m}^{2}$ ) (Tabela 12) (referência: manejo). 36 


\section{LISTA DE TABELAS}

Página

Tabela 1. Esquema da análise da variância individual para cada experimento (12 parcelas)....... 14

Tabela 2. Esquema da análise da variância conjunta para os dois experimentos. 15

Tabela 3. Datas de amostragens, estádio fenológico correspondente e lâminas aplicadas.

Tabela 4. Especificações técnicas do equipamento de irrigação. 23

Tabela 5. Resultados das observações fenológicas. 24

Tabela 6. Temperaturas máxima $\left(\mathrm{T}_{1},{ }^{\circ} \mathrm{C}\right)$ e mínima $\left(\mathrm{T}_{2},{ }^{\circ} \mathrm{C}\right)$ do ar, número de graus-dia no $\left(\mathrm{GDi},{ }^{\circ} \mathrm{C}\right.$. dia $)$ e até $\left(\mathrm{GDAi},{ }^{\circ} \mathrm{C}\right.$.dia) o í-ésimo dia após a emergência, estádio fenológico, número de dias após a emergência (DAE) e desenvolvimento relativo da cultura (Dr) de milho desde a emergência ( 7 de setembro) até 5 folhas ( 7 de outubro). Departamento de Produção Vegetal, ESALQ, Universidade de São Paulo. Data da semeadura: 27 de agosto de 1998. Data de colheita: 21 de janeiro de 1999.

Tabela 7. Temperaturas máxima $\left(\mathrm{T}_{1},{ }^{\circ} \mathrm{C}\right)$ e mínima $\left(\mathrm{T}_{2},{ }^{\circ} \mathrm{C}\right)$ do ar, número de graus-dia no $\left(\mathrm{GDi},{ }^{\circ} \mathrm{C} . d i a\right)$ e até $\left(\mathrm{GDAi},{ }^{\circ} \mathrm{C}\right.$.dia) o í-ésimo dia após a emergência, estádio fenológico, número de dias após a emergência (DAE) e desenvolvimento relativo da cultura (Dr) de milho desde 5 folhas ( 8 de outubro) até 13 folhas (5 de novembro). Departamento de Produção Vegetal, ESALQ, Universidade de São Paulo. Data da semeadura: 27 de agosto de 1998. Data de colheita: 21 de janeiro de 1999. 
Tabela 8. Temperaturas máxima $\left(\mathrm{T}_{1},{ }^{\circ} \mathrm{C}\right)$ e mínima $\left(\mathrm{T}_{2},{ }^{\circ} \mathrm{C}\right)$ do ar, número de graus-dia no (GDi, ${ }^{\circ} \mathrm{C}$.dia) e até (GDAi, ${ }^{\circ} \mathrm{C}$.dia) o i-ésimo dia após a emergência, estádio fenológico, número de dias após a emergência (DAE) e desenvolvimento relativo da cultura (Dr) de milho desde 13 folhas (6 de novembro) até grão pastoso (6 de dezembro). Departamento de Produção Vegetal, ESALQ, Universidade de São Paulo. Data da semeadura: 27 de agosto de 1998. Data de colheita: 21 de janeiro de 1999.

Tabela 9. Temperaturas máxima $\left(\mathrm{T}_{1},{ }^{\circ} \mathrm{C}\right)$ e mínima $\left(\mathrm{T}_{2},{ }^{\circ} \mathrm{C}\right)$ do ar, número de graus-dia no (GDi, ${ }^{\circ} \mathrm{C}$.dia) e até (GDAi, ${ }^{\circ} \mathrm{C}$.dia) o i-ésimo dia após a emergência, estádio fenológico, número de dias após a emergência (DAE) e desenvolvimento relativo da cultura (Dr) de milho desde grão pastoso ( 7 de dezembro) até o ponto de maturidade (6 de janeiro). Departamento de Produção Vegetal, ESALQ, Universidade de São Paulo. Data da semeadura: 27 de agosto de 1998. Data de colheita: 21 de janeiro de 1999. 28

Tabela 10. Modelo referente à estimativa do índice de área foliar (IAF, $\mathrm{m}^{2} / \mathrm{m}^{2}$ ) em função da população de plantas $\left(\mathrm{P}, \mathrm{pl} / \mathrm{m}^{2}\right)$ e do desenvolvimento relativo da cultura (Dr), com os respectivos valores do coeficiente de correlação (r), número de observações (n), desvio padrão do erro (s, $\mathrm{m}^{2} / \mathrm{m}^{2}$ ), e valor F (Figura 7)

Tabela 11. Modelos referentes à estimativa da lâmina média retida $(h, m m)$ em função do indice de área foliar (IAF, $\mathrm{m}^{2} / \mathrm{m}^{2}$ ) e do desenvolvimento relativo da cultura (Dr), com os respectivos valores do coeficiente de correlação (r), número de observações (n), desvio padrão do erro (s, $\mathrm{mm}$ ), e valor $\mathrm{F}$. 
Tabela 12. Modelos referentes à estimativa do volume de água médio retido ( $\mathrm{Vr}$, 1/ha) pela cultura de milho em função do índice de área foliar (IAF, $\mathrm{m}^{2} / \mathrm{m}^{2}$ ) (Figura 11) e da população de plantas $\left(\mathrm{pl} / \mathrm{m}^{2}\right)$ e do desenvolvimento relativo da cultura (Dr) (Figura 10), com os respectivos valores do coeficiente de correlação ( $r$ ), número de observações (n), desvio padrão do erro (s, mm), e valor $F$.

Tabela 13. Análise de variância relativa ao indice de área foliar (IAF, $\mathrm{m}^{2} / \mathrm{m}^{2}$ ) correspondente ao experimento Ll.

Tabela 14. Valores médios de indice de área foliar (IAF, $\mathrm{m}^{2} / \mathrm{m}^{2}$ ) para cada população $\left(\mathrm{P}, \mathrm{pl} / \mathrm{m}^{2}\right)$ e cada época de avaliação $(\mathrm{E})$ e teste de comparação dos valores médios de IAF entre populações e entre épocas no experimento $\mathrm{L} 1$

Tabela 15. Valores médios de indice de área foliar (IAF, $\mathrm{m}^{2} / \mathrm{m}^{2}$ ) para cada combinação população $\left(\mathrm{P}, \mathrm{pl} / \mathrm{m}^{2}\right) \times$ época de avaliação (E) no experimento L1 e teste de comparação dos valores médios de IAF entre os tratamentos $\mathrm{P} \times \mathrm{E}$.

Tabela 16. Análise de variância relativa ao indice de área foliar (IAF, $\mathrm{m}^{2} / \mathrm{m}^{2}$ ) correspondente ao experimento L2.

Tabela 17. Valores médios de índice de área foliar (IAF, $\mathrm{m}^{2} / \mathrm{m}^{2}$ ) para cada população $\left(\mathrm{P}, \mathrm{pl} / \mathrm{m}^{2}\right)$ e cada época de avaliação $(\mathrm{E})$, e teste de comparação dos valores médios de IAF entre populações e entre épocas no experimento L2.

Tabela 18. Valores médios de indice de área foliar (IAF, $\mathrm{m}^{2} / \mathrm{m}^{2}$ ) para cada combinação população $\left(\mathrm{P}, \mathrm{pl} / \mathrm{m}^{2}\right) \mathrm{x}$ época de avaliação (E) no experimento L2 e teste de comparação dos valores médios de IAF entre os tratamentos $\mathrm{P} \times \mathrm{E}$.

Tabela 19. Análise de variância relativa à lâmina de água retida (h, mm) correspondente ao experimento $\mathrm{L} l$. 
Tabela 20. Valores médios de lâmina de água retida para cada população ( $P$, $\mathrm{pl} / \mathrm{m}^{2}$ ) e cada época de avaliação (E) e teste de comparação dos valores médios de lâmina de água retida entre populações e entre épocas no experimento L1.

Tabela 21. Valores médios de lâmina de água retida para cada combinação população $\left(\mathrm{P}, \mathrm{pl} / \mathrm{m}^{2}\right) \times$ época de avaliação $(\mathrm{E})$ no experimento $\mathrm{Lle}$ teste de comparação dos valores médios de lâmina de água retida entre os tratamentos $\mathrm{P} \times \mathrm{E}$

Tabela 22. Análise de variância relativa à lâmina de água retida ( $\mathrm{h}, \mathrm{mm}$ ) correspondente ao experimento L2.

Tabela 23. Valores médios de lâmina de água retida para cada população $(P$, $\mathrm{pl} / \mathrm{m}^{2}$ ) e cada época de avaliação (E) e teste de comparação dos valores médios de lâmina de água retida entre populações e entre épocas no experimento L2

Tabela 24. Valores médios de lâmina de água retida para cada combinação população $\left(\mathrm{P}, \mathrm{pl} / \mathrm{m}^{2}\right)$ época de avaliação (E) no experimento $\mathrm{L} 2$ e teste de comparação dos valores médios de lâmina de água retida entre os tratamentos $\mathrm{P} \times \mathrm{E}$.

Tabela 25. Análise de variância relativa ao volume de água retido ( $\mathrm{Vr}, \mathrm{l} / \mathrm{ha}$ ) correspondente ao experimento $\mathrm{L} 1$.

Tabela 26. Valores médios de volume de água retido para cada população ( $\mathrm{P}$, $\mathrm{pl} / \mathrm{m}^{2}$ ) e cada época de avaliação (E) e teste de comparação dos valores médios de volume de água retido entre populações e entre épocas no experimento $\mathrm{L} 1$.

Tabela 27. Valores médios de volume de água retido para cada combinação população $\left(\mathrm{P}, \mathrm{pl} / \mathrm{m}^{2}\right) \times$ época de avaliação $(\mathrm{E})$ no experimento $\mathrm{L} 1 \mathrm{e}$ teste de comparação dos valores médios de volume de água retido entre os tratamentos $\mathrm{P} \times \mathrm{E}$.

Tabela 28. Análise de variância relativa ao volume de água retido ( $\mathrm{Vr}, \mathrm{I} / \mathrm{ha})$ correspondente ao experimento L2 (Lâmina: 1,3 mm). 
Tabela 29. Valores médios de volume de água retido para cada população $(\mathrm{P}$, $\mathrm{pl} / \mathrm{m}^{2}$ ) e cada época de avaliação (E) e teste de comparação dos valores médios de volume de água retido entre populações e entre épocas no experimento L2.

Tabela 30. Valores médios de volume de água retido para cada combinação população $\left(\mathrm{P}, \mathrm{pl} / \mathrm{m}^{2}\right)$ x época de avaliação $(\mathrm{E})$ no experimento $\mathrm{L} 2 \mathrm{e}$ teste de comparação dos valores médios de volume de água retido entre os tratamentos $\mathrm{P} \times \mathrm{E}$.

Tabela 31. Análise de variância conjunta para os experimentos L1 (Lâmina: 3,6 $\mathrm{mm}$ ) e L2 (Lâmina: 1,3 mm) relativa ao volume de água retido ( $\mathrm{Vr}$, 1/ha)

Tabela 32. Valores médios de volume de água retido para população $\left(\mathrm{P}, \mathrm{pl} / \mathrm{m}^{2}\right)$, lâmina aplicada (L), lâmina x população e época de avaliação, segundo a análise conjunta dos experimentos L1 e L2; e teste de comparação dos valores médios de volume de água retido.

Tabela 33. Valores médios de volume de água retido para população $\left(\mathrm{P}, \mathrm{pl} / \mathrm{m}^{2}\right) \mathrm{x}$ época de avaliação (E) e lâmina aplicada ( $\mathrm{L}, \mathrm{mm}$ ) $\mathrm{x}$ época de avaliação, segundo a análise conjunta dos experimentos $\mathrm{L}$ l (3,6 mm) e L2 $(1,3 \mathrm{~mm})$ e teste de comparação dos valores médios de volume de água retido

Tabela 34. Valores observados (IAFo, $\mathrm{m}^{2} / \mathrm{m}^{2}$ ) e estimados (IAFe, $\mathrm{m}^{2} / \mathrm{m}^{2}$ ) do indice de área foliar em função do desenvolvimento relativo (Dr) e da população de plantas $\left(\mathrm{P}, \mathrm{p} / \mathrm{m}^{2}\right)$, desvio (d) entre os valores observados e estimados, erro relativo ( $\mathrm{Er}, \%$ ), e limites inferior (Llic) e superior (LSic) do intervalo de confiança ao nível de $95 \%$ de probabilidade.

Tabela 35. Valores observados (ho, $\mathrm{mm}$ ) e estimados (he, $\mathrm{mm}$ ) da lâmina de água retida em função do índice de área foliar (IAF, $\mathrm{m}^{2} / \mathrm{m}^{2}$ ), desvio (d) entre os valores observados e estimados, erro relativo ( $\mathrm{Er}, \%)$, e limites inferior (LIic) e superior (LSic) do intervalo de confiança ao nível de $95 \%$ de probabilidade. 
Tabela 36. Valores observados (Vro, mm) e estimados (Vre, 1/ha) de volume de água retida em função do indice de área foliar (IAF, $\mathrm{m}^{2} / \mathrm{m}^{2}$ ), desvio (d) entre os valores observados e estimados, erro relativo (Er, \%), e limites inferior (LIic) e superior (LSic) do intervalo de confiança ao nível de $95 \%$ de probabilidade.

Tabela 37. Valores observados (Vro, $\mathrm{m}^{2} / \mathrm{m}^{2}$ ) e estimados (Vre, $\mathrm{m}^{2} / \mathrm{m}^{2}$ ) de volume de água retida em função do desenvolvimento relativo (Dr) e da população de plantas $\left(\mathrm{P}, \mathrm{pl} / \mathrm{m}^{2}\right)$, desvio (d) entre os valores observados e estimados, erro relativo (Er, \%), e limites inferior (Llic) e superior (LSic) do intervalo de confiança a o nível de $95 \%$ de probabilidade. 


\title{
MODELO PARA ESTIMATIVA DO VOLUME MÁXIMO DE CALDA VISANDO A APLICAÇÃO FOLIAR DE PRODUTOS QUÍMICOS NA CULTURA DE MLHO (Zea mays L.)
}

\author{
Autora: María del Valle Basanta \\ Orientador: Prof. Dr. Durval Dourado-Neto
}

\section{RESUMO}

Com o objetivo de estimar o volume de água por hectare retido na folhagem da cultura de milho para fins de quimigação foliar, foram propostos dois modelos (estatístico e universal) e conduzido um experimento em que foi determinada a interceptação de água pela parte aérea das plantas de milho sob diferentes lâminas de irrigação aplicadas via pivô central. Foram avaliadas duas lâminas de irrigação e três populações de plantas do híbrido de milho C-909 em 3 estádios fenológicos: i) 4-5 folhas; ii) 8 folhas e iii) 14 folhas. A quantidade de água retida nas folhas das plantas foi estimada subtraindo da massa total da planta (medida após a passagem do pivô), a massa de matéria seca e a água constitutiva das plantas. A área foliar foi avaliada em cada amostragem. A fenologia e o desenvolvimento relativo da cultura foram avaliados periodicamente. Os resultados permitiram verificar que os modelos propostos são utilizáveis. 


\title{
MODEL TO ESTIMATE THE MAXIMUM WATER VOLUME FOR CHEMICAL PRODUCTS APPLICATION PURPOSES IN THE CORN (Zea mays L.) CROP FOLIAGE
}

\author{
Author: María del Valle Basanta \\ Adviser: Prof. Dr. Durval Dourado-Neto
}

\section{SUMMARY}

With the objective of estimating the water volume per area (ha) in the corn leaves for chemigation purposes, the statistic and universal models were proposed and a field experiment was carried out to obtain the water interception in the aerial corn plant parts under center pivot irrigation system. Two irrigation depths and three corn plant populations, using the hybrid C-909, were evaluated in three phenological stages: i) 4-5 leaves; ii) 8 leaves and iii) 14 leaves. The water mass retained in the corn leaves were obtaining considering the total plant mass measured after irrigation, the dry matter plant mass and the constitutive water mass. The total leaf area per corn plant was evaluated for each sampling period. The phenology and the relative crop development were evaluated periodically. The results allowed verify that the proposed models can be used for their purpose. 


\title{
MODELO PARA ESTIMAR EL VOLUMEN MÁXIMO DE AGUA PARA LA APLICACIÓN FOLIAR DE PRODUCTOS QUÍMICOS EN EL CULTIVO DE MAÍZ (Zea mays L.)
}

\author{
Autora: María del Valle Basanta \\ Director: Prof. Dr. Durval Dourado-Neto
}

\section{RESUMEN}

Con el objetivo de estimar el volumen de agua por hectarea retenido en la parte foliar del cultivo de maíz para propósitos de quimigación foliar, fueron propuestos dos modelos (estadístico y universal) y conducido un experimento en que fue determinada la intercepción de agua por la parte aerea de las plantas de maiz bajo riego por aspersión con pivote central. Fueron evaluadas dos láminas de riego y tres densidades de plantas del híbrido de maiz C-909 en tres estadíos fenológicos del cultivo: i) 4-5 hojas; ii) 8 hojas y iii) 14 hojas. La cantidad de agua retenida en las hojas de las plantas fue estimada sustrayendo de la masa total de la planta (medida inmediatamente después de la aplicación del agua en la parcela), la masa de materia seca y el agua constituyente de las plantas. Se evaluó en cada muestreo el área foliar y la fenologia y periódicamente el desarrollo relativo del cultivo. Los resultados permitieron verificar que el modelo propuesto es utilizable. 


\section{INTRODUÇÃo}

Em todos os sistemas de produção é necessário otimizar o uso dos recursos produtivos. Isso se obtém através da obtenção de alta produtividade e da redução dos custos de produção. Para as culturas em geral, o uso da técnica de irrigação e a aplicação de agroquímicos são fundamentais se o objetivo é a obtenção de altos rendimentos.

Com a quimigação é possivel uma aplicação segura e efetiva da quantidade apropriada de produto pelo qual reduz-se os custos de produção enquanto se protege o operário e o meio ambiente (Leon New, 1990).

O sucesso da quimigação, tendo como alvo tanto o solo quanto a folhagem, depende em grande parte da uniformidade de aplicação do produto, a qual é geralmente proporcional à uniformidade de distribuição da água pelo sistema de irrigação.

A medição da uniformidade de distribuição da água mediante o coeficiente de uniformidade permite a comparação dos diferentes sistemas de irrigação em relação a esse parâmetro. Porém, esse coeficiente reflete apenas a forma com que é distribuída a água no solo pelo sistema de irrigação na ausência da cultura.

$\mathrm{Na}$ presença da cultura, a água aplicada pelo sistema de irrigação será redistribuida entre a parte aérea das plantas e o solo. Essa distribuição dependerá de fatores do sistema de irrigação (caracterizados pelo coeficiente de uniformidade e a lâmina aplicada, principalmente), do clima (velocidade do vento e evaporação) e da cultura (espécie, densidade de semeadura e arquitetura de planta, disposição das folhas na planta e ângulo de inserção, e estádio fenológico).

Sendo assim, fica evidente a importância da cultura na distribuição da água de irrigação e da necessidade de se verificar a potencialidade da aplicação de agroquimicos na folhagem das culturas através dos sistemas de irrigação.

O presente trabalho foi realizado com o intuito de servir de subsidio para definir 
a viabilidade técnica da quimigação cujo o alvo é folha. Para tal foram consideradas as seguintes hipóteses de trabalho: i) a eficiência de aplicação do produto químico é diretamente proporcional à quantidade do produto que atinge o alvo folha; ii) a quantidade do produto que atinge as folhas é dependente da área foliar total, a qual depende da idade, população, espaçamento, distribuição e arquitetura das plantas na área, principalmente; iii) a quantidade do princípio ativo que atinge as folhas depende da calda (1/ha) utilizada; iv) a distribuição do produto químico é a mesma da água de irrigação devido ao regime de escoamento hidráulico.

O objetivo deste trabalho foi avaliar o efeito de diferentes distribuições espaciais (populações) e índices de área foliar da cultura de milho, e de diferentes lâminas de aplicação de água de irrigação em relação à interceptação da mesma pela parte aérea das plantas sob irrigação (pivô central), no intuito de estimar o volume máximo de calda visando a aplicação foliar de produtos químicos na cultura de milho. 


\section{REVISÃO DE LITERATURA}

\subsection{A cultura de milho}

\subsubsection{Importância do milho}

O milho é um dos mais importantes cereais cultivado no mundo devido a sua composição e valor nutritivo, superado apenas pelo trigo e o arroz (Purseglove, 1972; Fancelli, 1994).

O Brasil ocupa o terceiro lugar entre os produtores mundiais de milho com aproximadamente $8 \%$ da produção total, embora se posiciona em décimo segundo lugar em relação à produtividade (Fancelli \& Lima, s/d).

Dentre os fatos que fazem do milho uma das culturas mais importantes no Brasil, pode-se mencionar: i) é a cultura que ocupa maior área cultivada, ii) é responsável pelo maior emprego de mão-de-obra no setor agrícola, iii) é o principal fornecedor de insumos alimentícios para a produção animal, e iv) é plantada em todo o território nacional (Embrapa, 1981).

O rendimento médio no Brasil, ao redor de $2300 \mathrm{~kg} \cdot \mathrm{ha}^{-1}$ é muito baixo (Bull, 1993). Uma das formas de se aumentar o rendimento da cultura é, sem dúvida, a adoção da prática da irrigação.

Além da cultura de arroz, a cultura de milho encontra-se entre as principais culturas anuais irrigadas junto com a cultura de feijão, principalmente com a utilização da irrigação por aspersão convencional e pivô central (Folegatti, 1994).

Sendo a irrigação uma prática que exige altas produtividades devido a seu alto custo de implantação, manutenção e operação, a cultura de milho tem sido utilizada como uma das alternativas para agricultura irrigada. (Resende et al., 1990, 1993).

A adoção da técnica de quimigação permite reduzir os custos de produção, 
conseqüentemente a cultura de milho irrigado torna-se mais rentável.

\subsubsection{Fenologia do milho}

O conhecimento das fases de desenvolvimento de uma cultura é fundamental em estudos de distribuição de água aplicada devido à variabilidade espacial do índice de área foliar que modifica essa distribuição (Goodmann \& Smith, 1978).

Em culturas anuais a interceptação aumenta com a idade da cultura devido ao acréscimo da cobertura do solo pelas folhas, com posterior queda no período de maturação. O contrário acontece com a precipitação interna, que é inversamente proporcional à idade da cultura (Leopoldo et al., 1981).

O ciclo da cultura de milho compreende diferentes etapas de desenvolvimento (Fancelli, 1994): i) emergência (cerca de 7 a 10 dias): período da semeadura até o aparecimento da plântula; ii) crescimento vegetativo (extensão variável, dependendo da precocidade do material), da emissão da segunda folha até o início do florescimento; iii) florescimento (cerca de 8 a 10 dias): período desde o início da polinização até o início da frutificação; iv) frutificação (cerca de 50 a 60 dias): etapa compreendida entre o início do enchimento dos grãos até o início da maturação; v) maturação (cerca de 25 a 35 dias): etapa desde o final da maturação até o ponto de maturidade fisiológica.

Essas etapas podem ser divididas em onze estádios distintos de desenvolvimento: i) estádio 0 (emergência); ii) estádio 1 (planta com 4 folhas totalmente desdobradas); iii) estádio 2 (planta apresentando 8 folhas); iv) estádio 3 (plantas com 12 folhas); v) estádio 4 (emissão do pendão); vi) estádio 5 (florescimento); vii) estádio 6 (grãos leitosos); viii) estádio 7 (grãos pastosos); ix) estádio 8 (início da formação de “dentes”); x) estádio 9 (grãos “duros”); xi) estádio 10 (grãos maduros fisiologicamente).

Essa divisão das etapas de desenvolvimento em estádios facilita o manejo (referência exata) e o estudo da cultura, bem como objetiva a possibilidade do estabelecimento de correlações entre elementos fisiológicos, bioquímicos, climatológicos, fitogenéticos, entomológicos, fitopatológicos e fitotécnicos com o desempenho da planta referente ao atributo de interesse (Fancelli, 1986a, 1986b; Fancelli \& Dourado-Neto, 1992). 


\subsection{A quimigação e a irrigação por aspersão via pivô central}

Sendo possivel a utilização da quimigação com todos os métodos de irrigação, eles apresentam alguns usos mais apropriados e, em muitos casos impõem restrições ao tipo de produto químico a ser aplicado.

Particularmente, na irrigação por aspersão pode-se aplicar os produtos químicos tanto no solo quanto nas folhas das plantas, enquanto que os sistemas de irrigação por superficie e por gotejamento, só permitem aplicar o agroquímico ao solo.

A maioria dos inseticidas, fungicidas, agentes de controle biológico e herbicidas pós-emergentes precisa ser aplicado na parte aérea das plantas (Vieira, 1994).

No manejo da irrigação é fundamental obter uma aplicação uniforme de água. Essa necessidade é ainda maior quando se trata da quimigação. A uniformidade de distribuição do produto químico é geralmente proporcional à uniformidade de distribuição da água pelo sistema de irrigação.

Christiansen (1942) foi o primeiro a estudar a uniformidade de distribuição em aspersão, quantificando-a através de um índice denominado coeficiente de uniformidade de Christiansen (CUC), onde é utilizado o desvio médio como medida de dispersão.

Os equipamentos de irrigação por aspersão pivô central e lineares apresentam elevados coeficientes de uniformidade, sendo opções muito adequadas para a quimigação. Em particular o pivô central, supera em uniformidade as pulverizações terrestres e aéreas (Threadgill, 1985).

Em relação às aplicações de agroquímicos tendo como alvo as folhas das plantas, a principal desvantagem do pivô central é o grande volume de água aplicado resultando numa concentração do produto muito baixa. No Brasil, os pivôs centrais comerciais aplicam lâminas mínimas de 4 a $9 \mathrm{~mm}$ por volta (40 a $90 \mathrm{mil}$ litros/ha) e a maior parte da água é depositada no solo (Vieira, 1994).

$\mathrm{O}$ alto volume de água aplicada parece causar uma distribuição mais uniforme do produto através de toda a planta, atingindo a parte inferior da folhagem. Essa melhor redistribuição contribui a uma boa efetividade, mesmo sendo pequena a concentração do produto na água de irrigação (McMaster \& Douglas, 1976). 


\subsection{Fertirrigação, fungigação, herbigação e insetigação}

Quimigação é a técnica de aplicação de produtos químicos, a qual é denominada fertirrigação quando o produto químico específico é fertilizante, fungigação no caso de fungicidas, herbigação no caso de herbicidas e insetigação no caso de inseticidas (Dourado-Neto \& Fancelli, 1997).

Fertirrigação é a técnica referente à aplicação simultânea de água e fertilizantes cujo alvo é o solo, por meio de um sistema de irrigação. Os nutrientes diluídos na água são aplicados de forma a infiltrar no solo, predominando a absorção radical a não foliar (Coelho, 1994). Portanto, por definição a fertirrigação tem como alvo o solo e não a folhagem da cultura.

Por outro lado, chama-se de adubação foliar à aplicação de nutrientes minerais na folha vegetal, os quais serão absorvidos passivamente e ativamente e utilizados por toda a planta a fim de suprir deficiências (Camargo \& Silva, 1990). No processo evolutivo as folhas não perderam sua capacidade de absorver água e sais minerais. Essa propriedade possibilita a aplicação de adubos foliares (Boaretto \& Rosolém, 1987).

É importante salientar que o objetivo da adubação foliar não é substituir o fornecimento de nutrientes via solo. Só em alguns setores da agricultura, como a floricultura, essa substituição é economicamente viável (Camargo \& Silva, 1990).

Nos trabalhos que combinam as técnicas de irrigação e adubação foliar, a aplicação do fertilizante não é feita através da água de irrigação, sendo o mesmo aplicado às folhas com pulverizadores aéreos ou terrestres.

Em relação à fungigação, essa técnica tem sido adotada sem um adequado embasamento científico no Brasil, principalmente por agricultores que possuem pivôs centrais, nas regiões de agricultura inigada mais importantes do país (Almeida Pinto, 1994 citado por Fancelli, 1994).

Sendo uma prática recente no Brasil, as pesquisas locais são iniciais e escassas. Junqueira Netto (1990) menciona que nos Estados Únidos há mais de uma década se pratica a fungigação com resultados satisfatórios no controle das doenças foliares como a pinta preta (Alternaria solani) em batata, a cercosporiose (Cercospora beticola) em beterraba açucareira, a septoriose ou mancha de septória (Septoria lycopersici) em 
tomateiro, e mofo branco (Sclerotinia sclerotiorum) em feijoeiro.

Nessa mesma linha, há autores que afirmam que é possível uso da técnica de quimigação para aplicação de herbicidas (pré-plantio incorporado, pré-emergente e pósemergente). Citam ainda que no caso do herbicida aplicado em pós-emergência, há danos à cultura com as aplicações mecânicas tradicionais (Fancelli \& Dourado-Neto, 1992).

Os herbicidas aplicados em pós-emergência são absorvidos principalmente via foliar. O herbicida deve atingir as folhas das plantas daninhas de forma uniforme. Todavia isso não acontece em muitas situações de aplicação no campo, provocando falhas nos resultados (Victória Filho, 1990). Esse fato faz interessante a pesquisa relacionada à aplicação dos herbicidas via água de irrigação, já que uma boa calibração do equipamento de irrigação pode possibilitar obter uma aplicação uniforme.

No caso da instigação, o controle químico de pragas via injeção de inseticidas nas tubulações de irrigação começou na década de 60 nos Estados Unidos. No Brasil os primeiros relatos datam da década de 80 . Com o incremento da área agrícola irrigada, a insetigação tem sido aplicada através dos equipamentos de aspersão sem as pesquisas prévias necessárias para a sua eficiente utilização (Viana, 1994).

Embora a concentração do inseticida aplicada via água de irrigação seja muito baixa em comparação com uma aplicação convencional, o inseticida atinge a praga de forma mais eficiente, especificamente no caso da lagarta-do-cartucho. Isso também acontece em outras espécies com arquitetura semelhante à do milho, a qual favorece o escoamento da calda para o cartucho e às bainhas das folhas (Viana, 1994).

Pragas da cultura de milho como Helicoverpa zea (Young et al., 1984 citados por Viana, 1994), Spodoptera frugiperda (Young et al., 1984 e Viana \& Costa, 1989 citados por Viana, 1994) e Elasmopalpus lignosellus (Viana \& Costa, 1992 citados por Viana, 1994) têm sido bem controladas através da insetigação.

\subsection{Efeito da cultura na distribuição de água}

A cobertura vegetal da cultura provoca uma partição da água (seja chuva ou água de irrigação) entre as plantas e o solo, modificando distintos processos do ciclo 
hidrológico (recarga do solo em água, escoamento e evaporação). Quando se trata da irrigação por aspersão, o desenvolvimento da cultura, irá interferir no coeficiente de uniformidade e na eficiência de irrigação (Leopoldo et al., 1981).

A maior parte dos trabalhos sobre interceptação foliar foram feitos em ecossistemas florestais ou em culturas perenes de grande porte (Rao, 1987; Miranda \& Butler, 1986; Lima, 1976; Leopoldo, 1981), porém em culturas anuais não é muito freqüente encontrar trabalhos sobre o tema.

Leopoldo et al. (1981) encontraram que as perdas por interceptação foliar na cultura de cana-de-açúcar representaram só $4,1 \%$ do total da chuva. Isso demonstra que a fração interceptada em uma cultura de cana é relativamente pequena quando comparada às perdas que ocorrem em ecossistemas florestais, as quais atingem valores médios de $25 \%$ da precipitação total anual dependendo do tipo de cobertura florestal (Linsley et al., 1949).

Conte \& Leopoldo (1986) encontraram valores de interceptação foliar de 8,1\%, e de escoamento pelo colmo de $22 \%$ do total da chuva na cultura de milho.

Mundim (1996) estudou o efeito da cultura de milho na distribuição da água aplicada por aspersão convencional. Encontrou valores de escoamento pelo colmo de 45 a 50\% da água que atingiu o solo irrigado com lâminas de 3 e $4 \mathrm{~mm}$, e que a precipitação interna (água que atinge o solo através da folhagem) é intensificada com o aumento da lâmina aplicada.

Da Silva et al. (1994) avaliaram um modelo de simulação da precipitação efetiva na cultura de milho sob irrigação por aspersão convencional. O modelo simulou uma interceptação foliar de $26 \%$ do total da água aplicada, enquanto a interceptação foliar medida de chuvas foi de $32 \%$ dessas chuvas. Os autores concluíram que os valores de interceptação foliar da água na cultura de milho, tanto em relação à irrigação quanto em relação a chuva natural, foram elevados. Por isso sugerem que a interceptação foliar seja considerada no manejo e no planejamento dos projetos de irrigação.

Mundim (1996) e Folegatti et al. (1998), avaliando a intercepção foliar de lâminas de irrigação por aspersão convencional na cultura do milho, encontraram que $44,5 \%$ e $50 \%$ da precipitação efetiva alcançou a superfície do solo via escoamento pelo 
colmo nas parcelas que receberam água com intensidade de 3 e $4 \mathrm{~mm} / \mathrm{h}$, enquanto na parcela com intensidade de $9 \mathrm{~mm} / \mathrm{h}$, o escoamento pelo colmo reduziu-se para $38,8 \%$. O aumento da intensidade de precipitação ocasionou aumento simultâneo do escoamento pelo colmo e da precipitação interna devido à diminuição das perdas por intercepção. Verificou-se que os valores de água interceptados pela cultura de milho são variados e devem ser determinados para cada situação específica no referente a índice de área foliar, espaçamento, cultivar e arquitetura da planta.

Steiner et al. (1983), avaliando a partição da água na cultura de milho sob irrigação por aspersão do tipo pivô central, estimaram a interceptação média de água nas folhas das plantas em $2,7 \mathrm{~mm}$ quando a cultura apresentou um indice de área foliar superior a 3. Consideraram que a capacidade de interceptação das plantas de milho depende do índice de área foliar, do espaçamento entre plantas e das características do material em relação ao ângulo de inserção das folhas e a sua senescência. Os autores citam Stoltemberg \& Wilson (1950), os quais encontraram que a interceptação da água pelas folhas das plantas de milho foi de $0,64 \mathrm{~mm}$ usando uma técnica de remoção das plantas do campo e a posterior medição da massa de água por pesagem.

Stone et al. (1994), estudando a distribuição de um inseticida aplicado na cultura de milho em irrigação por aspersão do tipo pivô central, observaram que o volume de água coletado aumentou a medida em que diminuiu a altura dos coletores em relação ao nível do solo, o que demostra o "efeito funil" da folhagem do milho.

Considerando que na maior parte dos estudos foi encontrado que uma fração importante da água aplicada é interceptada ou contribui à precipitação interna, é possivel pensar na viabilidade da aplicação de agroquímicos com sistemas de aspersão tendo como alvo as folhas das plantas. 


\section{MATERIAL E MÉTODOS}

\subsection{Local do experimento}

O experimento foi conduzido em Piracicaba-SP (22 $43^{\prime}$ latitude Sul, $47^{\circ} 38^{\prime}$ longitude Oeste, $580 \mathrm{~m}$ de altitude) na área experimental do Departamento de Produção Vegetal da ESALQ-USP (Figura 1). O solo da área é classificado como Terra Roxa Estruturada eutrófica, horizonte A moderado, textura argilosa/muito argilosa.

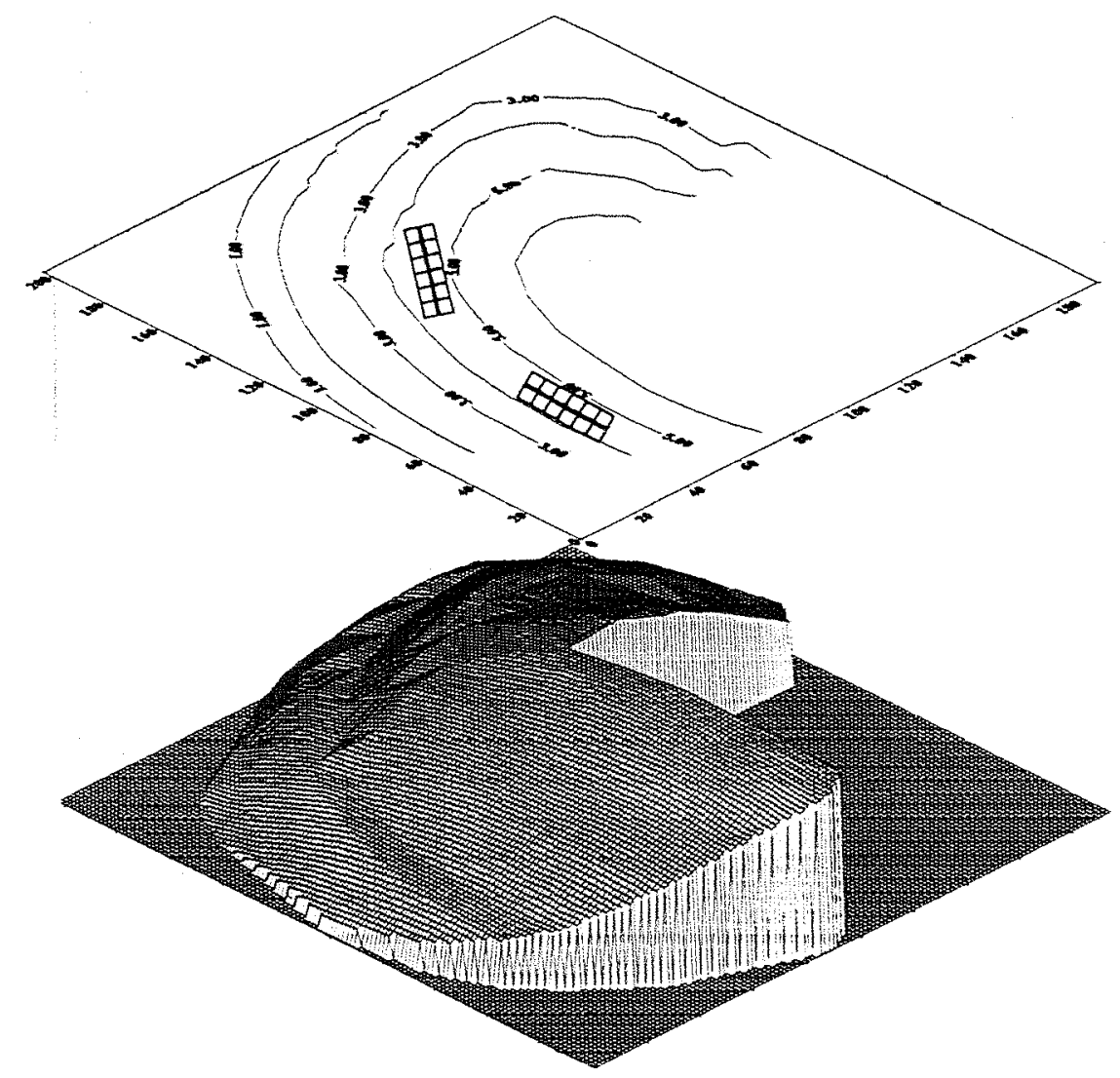

Figura 1. Disposição do conjunto experimental sob o pivô central da área experimental do Departamento de Produção Vegetal da ESALQ, Universidade de São Paulo. Piracicaba, SP. 


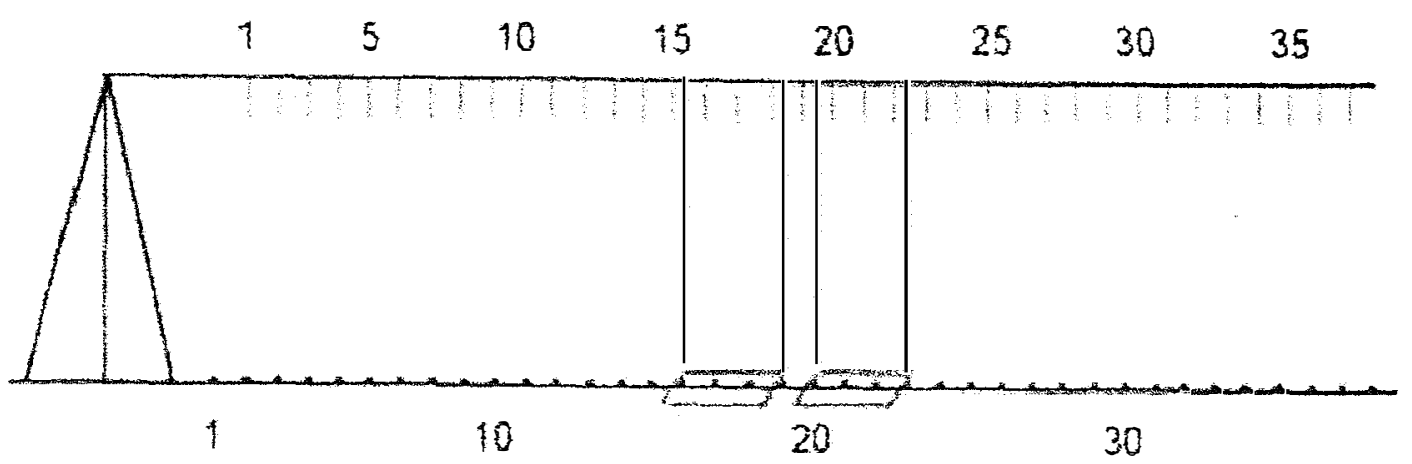

Aspersores

$\therefore$ Coletores

Ymarcias

Figura 2. Relação das parcelas com os aspersores e os coletores utilizados no teste de avaliação do pivô central.

\subsection{Instalação do experimento}

Foram instaladas 24 parcelas dispostas em 2 grupos de 12, correspondendo cada um deles a uma determinada lâmina de irrigação, tal como é detalhado na Figura 1.

A área total de cada parcela foi de $35,7 \mathrm{~m}^{2}$ ( $6 \mathrm{~m}$ de cumprimento e 7 fileiras de plantas com espaçamento de $0,85 \mathrm{~m}$ ) e a área útil de $17 \mathrm{~m}^{2}$ (Figura 4).

As populações (tratamentos) foram aleatoriamente distribuídas dentro de cada grupo de 12 parcelas e as lâminas de irrigação foram determinadas aleatoriamente entre os dois grupos de parcelas.

Foi semeado o híbrido de milho CARGILL 909 (classificação comercial quanto ao florescimento: super-precoce) em 27 de agosto de 98 com três densidades: i) 3,5 sementes/m linear e um espaçamento entre fileiras de $0,85 \mathrm{~m}$ (41.176 plantas/ha na colheita), ii) 4,5 sementes/m linear e um espaçamento entre fileiras de 0,85 m (52.941 plantas/ha na colheita), iii) 5,5 sementes/m linear e um espaçamento entre fileiras de 0,85 m (64.706 plantas/ha na colheita). As sementes foram tratadas com o fungicida thiabendazolle na dose de $300 \mathrm{~g} / 100 \mathrm{~kg}$. Para o controle de pragas, utilizou-se lambda cyalotrin para a lagarta rosca e lufenuron e clorpyrifos para a lagarta do cartucho. Para o controle da plantas daninhas foi usado nicosulfuron + bentazon. 
Foi feita adubação na semeadura com $30 \mathrm{~kg} / \mathrm{ha}$ de $\mathrm{N}$ (fonte: Sulfato de Amônio), $80 \mathrm{~kg} /$ ha de $\mathrm{P}_{2} \mathrm{O}_{5}$ (Fonte: Superfosfato Simples) e $50 \mathrm{~kg} / \mathrm{ha}$ de $\mathrm{K}_{2} \mathrm{O}$ (Fonte: Cloreto de Potássio). Posteriormente foram feitas duas adubações em cobertura: 39 $\mathrm{kg}$ /ha de N (Fonte: Uréia) em 1 de outubro de 1998, e $60 \mathrm{~kg} / \mathrm{ha}$ de N (Fonte: Uréia) em 27 de outubro de 1998.
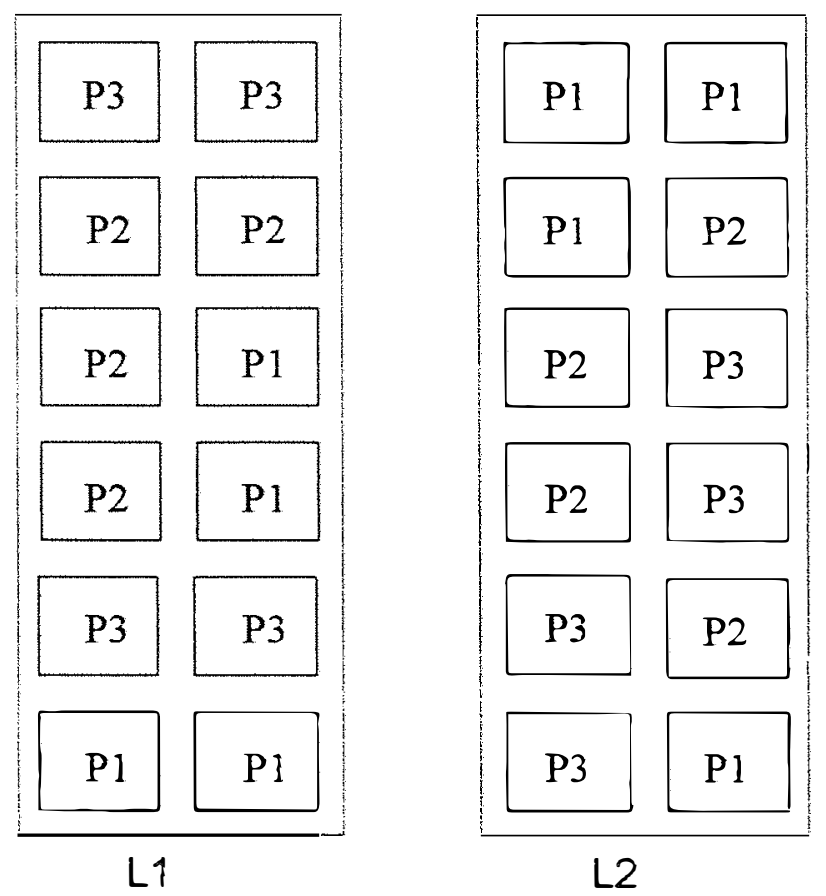

Figura 3. Representação esquemática da área experimental ilustrando a distribuição espacial das parcelas referentes aos três níveis (P1: 41.176, P2: 52.941 e P3: 64.706 plantas/ha) do tratamento (população) nos experimentos L1 (lâmina de irrigação: 3,6 mm) e L2 (lâmina de irrigação: $1,3 \mathrm{~mm}$ ). 


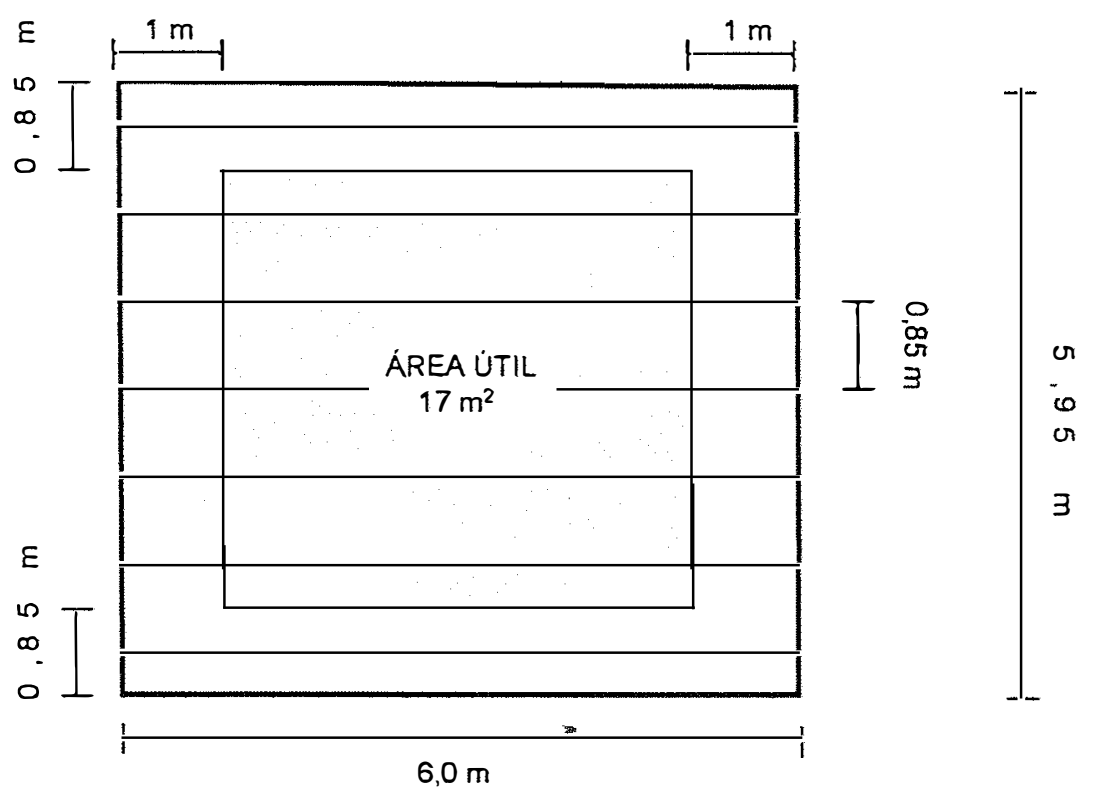

Figura 4. Desenho esquemático de uma parcela experimental.

\subsection{Análise estatística}

Para a análise estatística dos resultados dos experimentos L1 e L2 foi utilizado um delineamento em parcelas subdivididas. Para a análise da variância individual foi adotado o seguinte modelo:

$$
Y_{i j k}=\mu+t_{i}+e_{i j}+a_{k}+(t a)_{i k}+e_{i j k}
$$

em que óndice $i$ se refere ao número de ordem dos tratamentos ( $i=1$ a 3 ), $j$ ao número de ordem das repetições $(j=1$ a 4 ), $k$ ao número de ordem das épocas das avaliações (1 a 3), Yijk à observação da variável de interesse referente à j-ésima repetição do $i$-ésimo tratamento na $k$-ésima época de avaliação; $\mu$ à média geral; $\mathrm{t}_{i}$ ao efeito do $i$-ésimo tratamento; $\mathrm{e}_{i j}$ ao erro devido às parcelas experimentais, a $k$ ao efeito da $k$-ésima época de avaliação; (ta) $i k$ ao efeito da interação do $i$-ésimo tratamento com a $k$-ésima época de avaliação; e e $i j k$ ao erro devido às subparcelas.

O esquema da análise da variância para esse modelo está descrito na Tabela 1.

Para a análise conjunta dos dois experimentos foi adotado o seguinte modelo: 


$$
Y_{i j k}=\mu+t_{i}+l_{j}+e_{i j}+a_{k}+(t a)_{i k}+(l a)_{j k}+(t l a)_{i j k}+e_{i j k l}
$$

em que o índice $i$ se refere ao número de ordem dos tratamentos ( $i=1$ a 3 ), $j$ ao número de ordem das repetições $(j=1$ a 4$), k$ ao número de ordem das épocas das avaliações ( $k=1$ a 3), $l$ ao número de ordem das diferentes lâminas aplicadas ( $l=1$ a 2$), Y_{i j k}$ à observação da variável de interesse referente à $j$-ésima repetição do $i$-ésimo tratamento na $k$-ésima época de avaliação; $\mu$ à média geral; $\mathrm{t}_{i}$ ao efeito do $i$-ésimo tratamento; $\mathrm{e}_{i j}$ ao erro devido às parcelas experimentais, $a_{k}$ ao efeito da $k$-ésima época de avaliação; (ta) $i k$ ao efeito da interação do $i$-ésimo tratamento com a $k$-ésima época de avaliação; (la) jk ao efeito da interação da $j$-ésima lâmina aplicada com a $k$-ésima época de avaliação, (tla) $i j k$ ao efeito da interação do $i$-ésimo tratamento com a $j$-ésima lâmina aplicada na $k$-ésima época de avaliação e e $i j k l$ ao erro devido às subparcelas.

O esquema da análise da variância para esse modelo está descrito na Tabela 2.

Tabela 1. Esquema da análise da variância individual para cada experimento (12 parcelas).

\begin{tabular}{lccc}
\hline \multicolumn{1}{c}{ Causa da variação } & Graus de Liberdade* & Quadrado Médio & $\mathrm{F}$ \\
\hline Tratamentos (T) & $\mathrm{i}-1=3-1=2$ & $\mathrm{~V}_{1}$ & $\mathrm{~V}_{1} / \mathrm{V}_{2}$ \\
Resíduo (a) & $\mathrm{i}(\mathrm{j}-1)=3(4-1)=9$ & $\mathrm{~V}_{2}$ & \\
\hline (Parcelas) & $(\mathrm{ij}-1)=(3.4-1)=11$ & & \\
Épocas (E) & $\mathrm{k}-1=3-1=2$ & $\mathrm{~V}_{3}$ & $\mathrm{~V}_{3} / \mathrm{V}_{5}$ \\
T x E & $(\mathrm{i}-1)(\mathrm{k}-1)=(3-1) \cdot(3-1)=4$ & $\mathrm{~V}_{4}$ & $\mathrm{~V}_{4} / \mathrm{V}_{5}$ \\
Resíduo (b) & $\mathrm{i}(\mathrm{j}-1)(\mathrm{k}-1)=3(4-1)(3-1)=18$ & $\mathrm{~V}_{5}$ & \\
\hline Total & $\mathrm{ijk}-1=3.4 .3-1=35$ & & \\
\hline
\end{tabular}

* As letras representam o número máximo de ordem para cada caso 
Tabela 2. Esquema da análise da variância conjunta para os dois experimentos.

\begin{tabular}{|c|c|c|c|}
\hline $\begin{array}{l}\text { Causa da } \\
\text { variação }\end{array}$ & Graus de Liberdade* & $\begin{array}{l}\text { Quadrado } \\
\text { Médio }\end{array}$ & 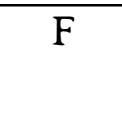 \\
\hline Lâmina (L) & $(\mathrm{I}-1)=(2-1)=1$ & $\mathrm{~V}_{1}$ & $\mathrm{~V}_{1} / \mathrm{V}_{4}$ \\
\hline Tratamentos $(\mathrm{T})$ & $(i-1)=(3-1)=2$ & $\mathrm{~V}_{2}$ & $\mathrm{~V}_{2} / \mathrm{V}_{4}$ \\
\hline $\mathrm{L} \times \mathrm{T}$ & $(I-1) \cdot(i-1)=(2-1) \cdot(3-1)=2$ & $\mathrm{~V}_{3}$ & $\mathrm{~V}_{3} / \mathrm{V}_{4}$ \\
\hline Resíduo (a) & $\mathrm{i}(\mathrm{j}-1)(\mathrm{i}-1)=3(4-1)(3-1)=18$ & $\mathrm{~V}_{4}$ & \\
\hline (Parcelas) & $(\mathrm{Iij}-1)=(2.3 .4-1)=23$ & & \\
\hline Épocas $(E)$ & $(k-1)=(3-1)=2$ & $\mathrm{~V}_{5}$ & $\mathrm{~V}_{5} / \mathrm{V}_{9}$ \\
\hline $\mathrm{T} \times \mathrm{E}$ & $(i-1)(k-1)=(3-1) \cdot(3-1)=4$ & $\mathrm{~V}_{6}$ & $\mathrm{~V}_{6} / \mathrm{V}_{9}$ \\
\hline$L \times E$ & $(\mathrm{I}-1)(\mathrm{k}-1)=(2-1) \cdot(3-1)=2$ & $\mathrm{~V}_{7}$ & $\mathrm{~V}_{7} / \mathrm{V}_{9}$ \\
\hline $\mathrm{E} \times \mathrm{L} \times \mathrm{T}$ & $(k-1)(I-1)(i-1)=(3-1)(2-1)(3-1)=4$ & $\mathrm{~V}_{8}$ & $\mathrm{~V}_{8} / \mathrm{V}_{9}$ \\
\hline Resíduo (b) & $\mathrm{i}(\mathrm{k}-1)(\mathrm{I}-1)(\mathrm{i}-1)(\mathrm{j}-1)=3(3-1)(2-1)(3-1)(4-1)=36$ & $\mathrm{~V}_{9}$ & \\
\hline Total & $($ lijk-1) $=(2 \cdot 3 \cdot 4 \cdot 3-1)=71$ & & \\
\hline
\end{tabular}

* As letras representam o número máximo de ordem para cada caso

\subsection{Fenologia}

A fenologia da cultura de milho foi avaliada utilizando a escala proposta por Fancelli (1986a, 1986b), a qual subdivide o ciclo da cultura em 11 diferentes estádios (0 a 10).

\subsection{Desenvolvimento relativo da cultura}

Foram calculados os valores de graus-dia acumulados para cada estádio, utilizando as temperaturas basais minima e máxima de $10{ }^{\circ} \mathrm{C}(\mathrm{Tb})$ e $30{ }^{\circ} \mathrm{C}(\mathrm{Tm})$, respectivamente. O desenvolvimento relativo $(\mathrm{Dr})$ foi calculado no final do ciclo dividindo a soma calórica acumulada até a data correspondente a cada estádio fenológico pela soma calórica total (índice térmico, IT) no ponto de maturidade fisiológica.

O desenvolvimento relativo da cultura foi calculado através da seguinte equação: 


$$
\mathrm{Dr}_{\mathrm{r}}=\frac{\sum_{\mathrm{i}=1}^{\mathrm{n}}\left(\mathrm{T}_{\mathrm{i}}-\mathrm{T}_{\mathrm{b}}\right)}{\mathrm{IT}},(\mathrm{Tb} \leq \mathrm{Ti} \leq \mathrm{Tm})
$$

em que $\operatorname{Dr}_{n}$ se refere ao estádio de desenvolvimento relativo da cultura até o n-ésimo dia após emergência $\left(0 \leq \operatorname{Dr}_{\mathrm{n}} \leq 1\right)$; $\mathrm{T}_{\mathrm{i}}$ à temperatura média $\left({ }^{\circ} \mathrm{C}\right)$ do ar no i-ésimo dia após a emergência; $\mathrm{Tb}$ à temperatura basal mínima da cultura $\left(10^{\circ} \mathrm{C}\right)$; $\mathrm{TT}$ ao índice térmico da cultura desde a emergência até o ponto de maturidade fisiológica; Tm à temperatura basal máxima da cultura $\left(30^{\circ} \mathrm{C}\right)$.

\section{6 Área foliar}

A determinação da área foliar foi realizada da seguinte maneira: i) foram escolhidas aleatoriamente 6 plantas na área adjacente a cada experimento (12 parcelas); ii) das folhas dessas plantas, foram retirados 30 círculos por planta $\left(n_{c}\right)$ de $0,9 \mathrm{~cm}$ de diâmetro $(2 \mathrm{r}, \mathrm{cm})$ (exceto na primeira amostragem da lâmina 2 em que foram retirados 20 círculos com diâmetro de $1,5 \mathrm{~cm}$ ), os quais foram secados e pesados, obtendo-se assim a correspondente massa de matéria seca; iii) com a área $\left(\mathrm{cm}^{2}\right)$ e a massa de matéria seca $\left(\mathrm{m}_{\mathrm{c}}, \mathrm{g}\right)$ dos $\mathrm{n}_{\mathrm{c}}$ círculos, foi obtida a área foliar específica $\left(\mathrm{AFe}, \mathrm{cm}^{2} / \mathrm{g}\right)$ :

$$
\mathrm{AFe}=\frac{\sum_{i=1}^{n_{c}} \pi \cdot r^{2}}{\sum_{i=1}^{n_{c}} m_{c}}
$$

Conhecendo-se a massa de matéria seca total das folhas das plantas amostradas em cada uma das 12 parcelas de cada experimento, calcula-se a área foliar total (AFT, $\mathrm{cm}^{2} / \mathrm{pl}$ ) de cada planta a partir da área foliar específica:

$$
A F T=M s f . A F e
$$

em que Msf se refere à massa de matéria seca das folhas por planta $(\mathrm{g} / \mathrm{pl})$.

Para o cálculo do índice de área foliar, utilizou-se a seguinte equação:

$$
I A F=\frac{A F T \cdot P}{10.000}
$$

em que $\mathrm{P}$ se refere à população de plantas $\left(\mathrm{pl} / \mathrm{m}^{2}\right)$. 


\subsection{Amostragens}

As amostragens foram feitas nos seguintes estádios fenológicos: i) 4 a 5 folhas, ii) 8 folhas e iii) 14 folhas. Na Tabela 3 são apresentadas as datas em que foram feitas as amostragens, o estádio fenológico correspondente e as lâminas aplicadas.

Em cada amostragem foram coletadas 2 plantas por parcela (exceto na primeira amostragem em que foram coletadas 3 plantas/parcela), totalizando 24 plantas por experimento (12 parcelas), mais as 6 plantas que foram coletadas antes da passagem do pivô para a estimativa do conteúdo de água constitutiva e determinação da área foliar (nessas 6 plantas foram coletados os círculos de folhas).

No período entre amostragens procedeu-se a pré-secagem das plantas, a separação das folhas do resto da plantas e a secagem em estufa, obtendo-se assim a massa de matéria seca de folhas (Msf, g) e a massa de matéria seca das outras partes das plantas (Msop, g).

Tabela 3. Datas de amostragens, estádio fenológico correspondente e lâminas aplicadas.

\begin{tabular}{ccc}
\hline & Primeira amostragem & \\
\hline Data & Estádio fenológico & Lâmina de irrigação \\
\hline 2 de outubro & $4-5$ folhas & $\mathrm{L2}^{1}$ \\
6 de outubro & $4-5$ folhas & $\mathrm{L1}^{2}$ \\
\hline & Segunda amostragem & \\
\hline Data & Estádio fenológico & Lâmina de irrigação \\
\hline 20 de outubro & 8 folhas & L2 \\
\hline 21 de outubro & 8 folhas & Lâmina de irrigação \\
\hline Data & Terceira amostragem & L1 \\
\hline 7 de novembro & Estádio fenológico & L2 \\
\hline
\end{tabular}

1 Regulagem do temporizador: $100 \%$. Lâmina de irrigação (L2): $1,3 \mathrm{~mm}$

2 Regulagem do temporizador: $40 \%$. Lâmina de irrigação (L1): $3,6 \mathrm{~mm}$ 


\subsection{Determinações}

\subsubsection{Determinação da lâmina de irrigação}

Para caracterização inicial da lâmina de irrigação, foram instalados coletores espaçados de 3 metros entre si, formando um ângulo entre as linhas de coletores de $3^{\circ}$, de acordo com as normas da ABNT (1985) (Figura 5).

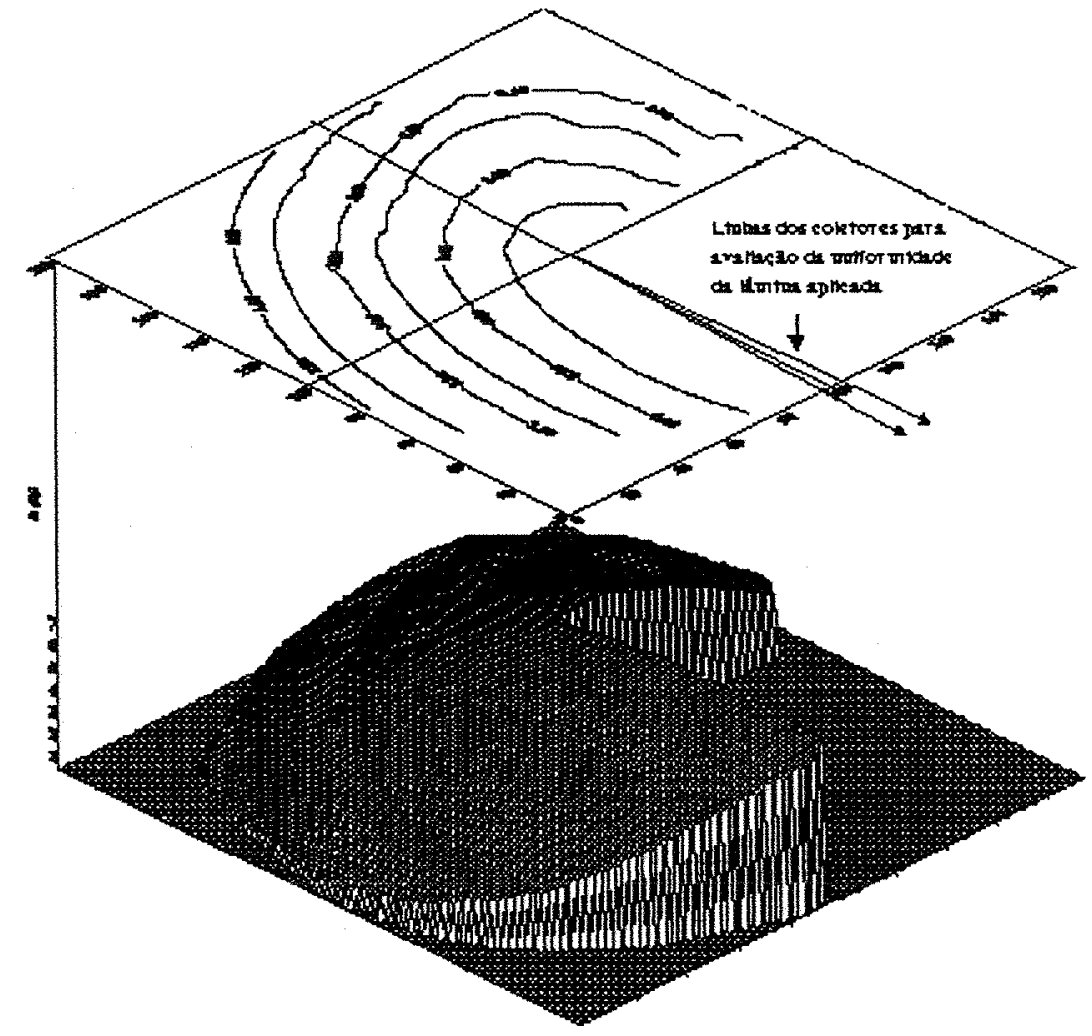

Figura 5. Disposição radial dos coletores sob o pivô para realização do teste de uniformidade de lâmina.

\subsubsection{Determinação da quantidade de água retida nas folhas}

Concebeu-se uma metodologia para avaliar diretamente a quantidade de água que fica retida nas folhas depois da irrigação (logo após de passar o pivô). Para isso, foi necessário tirar as plantas inteiras depois da irrigação de maneira que evitasse a queda da água das folhas.

As plantas foram coletadas em sacos plásticos e imediatamente pesadas para evitar qualquer perda de água. 
Por outro lado, foi necessário tirar plantas "controle" logo antes da irrigação para determinação do teor de água, assumindo-se que todas as plantas da lavoura, em um determinado momento do dia, têm o mesmo teor de água. Assim, conhecendo-se o teor de água e a massa de matéria seca da planta, pôde-se determinar a quantidade de água constitutiva.

As plantas depois de pesadas foram acondicionadas em casa-de-vegetação (présecagem) e depois secas em estufa a $70^{\circ} \mathrm{C}$ durante pelo menos $96 \mathrm{~h}$ (até peso constante).

Logo, o volume de água retido pelo folhagem é calculado pela diferença entre a massa da planta irrigada antes da secagem e a massa após a secagem, subtraindo-se o volume de água correspondente à massa de água constitutiva, assumindo massa específica da água de $1 \mathrm{~g} / \mathrm{cm}^{3}$.

O procedimento matemático desta metodologia é o seguinte:

i) determinação da massa de água armazenada sobre as folhas das plantas:

$$
\begin{aligned}
& \mathrm{m}_{\mathrm{t}}=\mathrm{m}_{\mathrm{wc}}+\mathrm{m}_{\mathrm{s}}+\mathrm{m}_{\mathrm{we}} \\
& \mathrm{m}_{\mathrm{we}}=\mathrm{m}_{\mathrm{t}}-\left(\mathrm{m}_{\mathrm{wc}}+\mathrm{m}_{\mathrm{s}}\right) \\
& \mathrm{U}=\frac{\mathrm{m}_{\mathrm{wc}}}{\left(\mathrm{m}_{\mathrm{s}}+\mathrm{m}_{\mathrm{wc}}\right)}
\end{aligned}
$$

Sendo assim:

$$
\begin{aligned}
\mathrm{m}_{\mathrm{wc}} & =\frac{\mathrm{U} \cdot \mathrm{m}_{\mathrm{s}}}{(1-\mathrm{U})} \\
\mathrm{m}_{\mathrm{we}} & =\mathrm{m}_{\mathrm{t}}-\frac{\mathrm{m}_{\mathrm{s}}}{(1-\mathrm{U})}
\end{aligned}
$$

em que $m_{t}$ se refere à massa $(\mathrm{g})$ total (planta irrigada antes da secagem), $\mathrm{m}_{w c}$ à massa $(\mathrm{g})$ água constitutiva, $\mathrm{m}_{\mathrm{s}}$ à massa $(\mathrm{g})$ de matéria seca (massa da planta irrigada após da

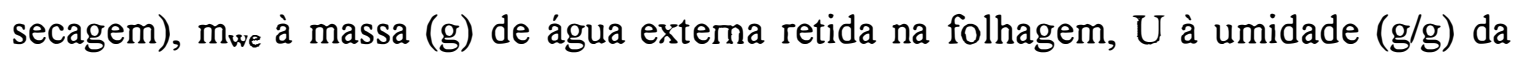
planta vizinha a base de massa (controle) base úmida;

ii)volume de água armazenado na folhagem das plantas: 


$$
\begin{aligned}
& \rho_{w}=\frac{m_{w}}{V_{w}} \\
& V_{w}=\frac{m_{w}}{\rho_{w}}
\end{aligned}
$$

Sendo assim:

$$
V_{w}=\left(\frac{m_{t}}{\rho_{w}}\right)-\left(\frac{m_{s}}{\rho_{w}}\right)\left[\frac{(2 U-1)}{(1-U)}\right]
$$

em que $\mathrm{V}_{\mathrm{w}}$ se refere ao volume $\left(\mathrm{cm}^{3} / \mathrm{pl}\right)$ de água armazenado na folhagem da planta e $\rho_{\mathrm{w}}$ à massa específica da água $\left(\mathrm{g} / \mathrm{cm}^{3}\right)$;

iii) determinação da área foliar específica e área foliar total (vide item 3.6);

iv) determinação da lâmina de água $(h, \mathrm{~mm})$ que fica retida nas folhas da planta:

$$
h=\frac{10 \cdot h w}{A F T}
$$

\subsubsection{Modelos propostos}

Com a finalidade de utilização prática, foram propostos os seguintes modelos: i) modelo universal e ii) modelo estatístico.

\subsubsection{Modelo universal}

No modelo universal, conhecendo-se a lâmina de água que fica nas folhas e o índice de área foliar, pode-se estimar o volume máximo de calda visando a aplicação foliar de produtos químicos na cultura de milho através da seguinte equação:

$$
\mathrm{Vr}=\mathrm{h} \cdot \mathrm{IAF} \cdot 10^{4}
$$

em que Vr se refere ao volume (1/ha) máximo retido de água (ou calda) na parte aérea das plantas; h à lâmina $(\mathrm{mm})$ de água retida; e IAF ao índice de área foliar $\left(\mathrm{m}^{2} / \mathrm{m}^{2}\right)$. 


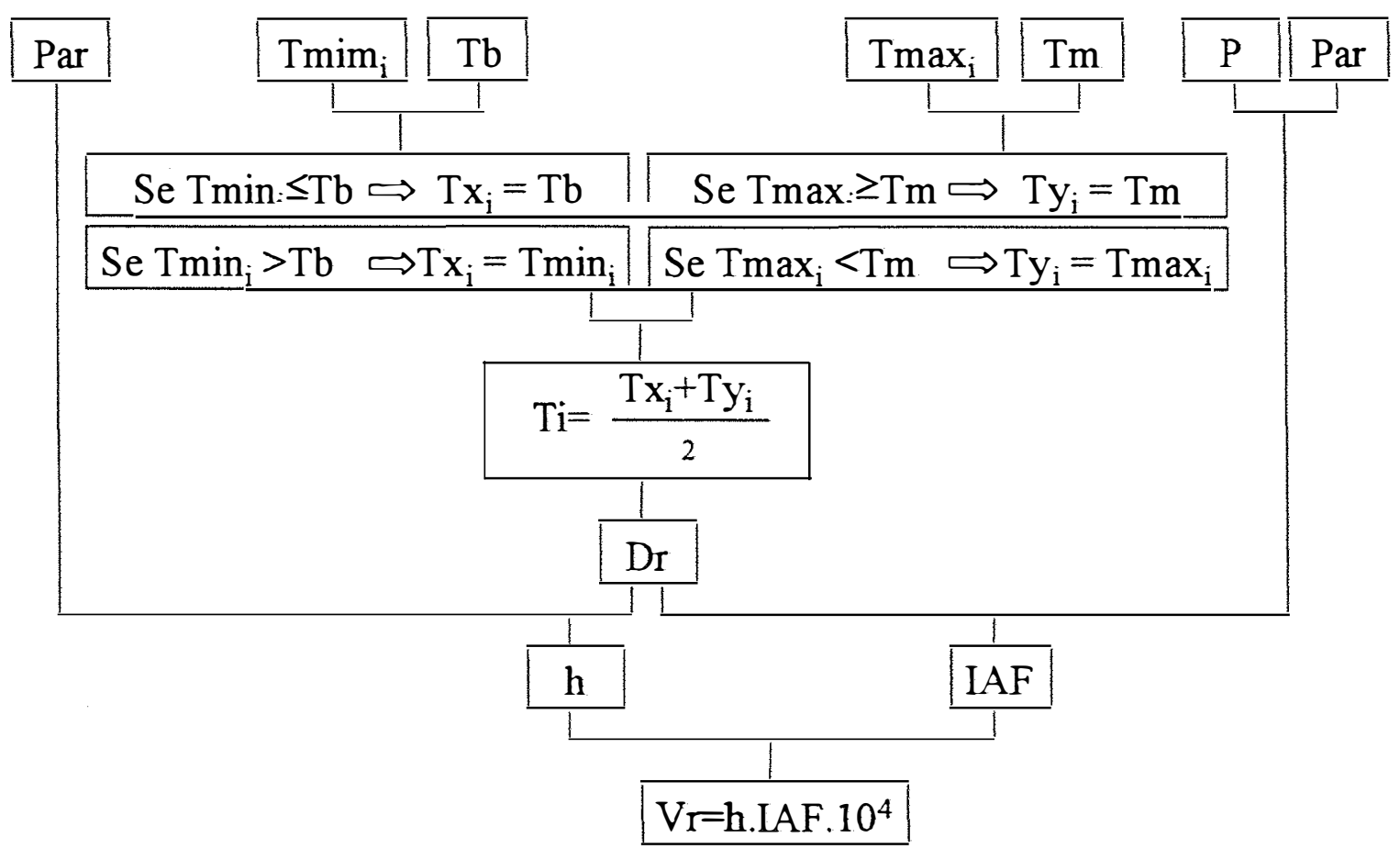

Figura 6. Fluxograma referente ao procedimento de estimativa do volume máximo de calda ( Vr, l/ha) retido na folhagem da cultura de milho. Tmin e $T_{i}$ se referem às temperaturas $\left({ }^{\circ} \mathrm{C}\right)$ mínima, máxima e média do ar, respectivamente; $\mathrm{Tb}$ e $\mathrm{Tm}$ às temperaturas $\left({ }^{\circ} \mathrm{C}\right)$ basais inferior e superior da cultura, respectivamente; $\mathrm{P}$ à população $\left(\mathrm{pl} / \mathrm{m}^{2}\right)$, Par aos parâmetros empíricos dos diferentes modelos, Dr ao desenvolvimento relativo da cultura, h à lâmina $(\mathrm{mm})$ de água retida e IAF ao índice de área foliar $\left(\mathrm{m}^{2} / \mathrm{m}^{2}\right)$.

Nesse caso, para estimativa da lâmina de água retida ( $\mathrm{h}, \mathrm{mm})$, foram concebidos dois modelos:

i) modelo utilizável como referência de planejamento:

$$
h=r^{\prime}\left(1-\mathrm{e}^{-s^{\prime} \cdot D r}\right)
$$

em que $r^{\prime}(\mathrm{mm})$ e $s^{\prime}$ se referem aos parâmetros empiricos do modelo, determinados através da análise de regressão não linear, minimizando a soma dos quadrados dos desvios. 
ii) modelo utilizável como referência de manejo:

$$
h=u\left(1-\mathrm{e}^{-v \cdot I A F}\right)
$$

em que $u(\mathrm{~mm})$ e $v$ se referem aos parâmetros empíricos do modelo, determinados através da análise de regressão não linear, minimizando a soma dos quadrados dos desvios.

Para o caso da estimativa do índice de área foliar para fins de planejamento, concebeu-se um modelo que apresenta como variáveis independentes a população de plantas $\left(\mathrm{P}, \mathrm{pl} / \mathrm{m}^{2}\right)$ e o desenvolvimento relativo da cultura (Dr):

$$
I A F=a^{\prime} \cdot \mathrm{e}^{-\frac{\frac{-D r+b^{\prime}}{r^{\prime}}}{2}}+d^{\prime} \cdot \mathrm{e}^{\frac{-P+k^{\prime}}{f^{\prime}}}+g^{\prime} \cdot \mathrm{e}^{-\frac{-D r+b^{\prime}}{c^{\prime}}} \cdot \mathrm{e}^{-\mathrm{e}^{\frac{-P+k^{\prime}}{S^{\prime}}}}
$$

em que $a^{\prime}, b^{\prime}, c^{\prime}, d^{\prime}, f^{\prime}, g^{\prime}$ e $k^{\prime}$ se referem aos parâmetros empíricos do modelo, determinados através da análise de regressão não linear, minimizando a soma dos quadrados dos desvios.

Por outro lado, para fins de manejo não foi concebido nenhum modelo para a estimativa do índice de área foliar $\left(\mathrm{IAF}, \mathrm{m}^{2} / \mathrm{m}^{2}\right)$ já que o mesmo pode ser observado in situ.

\subsubsection{Modelo estatístico}

$\mathrm{O}$ modelo estatístico pressupõe a estimativa do volume máximo de calda $(\mathrm{Vr}$, l/ha) com a finalidade i) de planejamento e ii) de manejo, fazendo a análise de regressão diretamente com os atributos tidos como variáveis independentes (desenvolvimento relativo, população e índice de área foliar).

O modelo estatístico, para fins de planejamento, propõe a utilização do desenvolvimento relativo da cultura $(\mathrm{Dr})$ e da população de plantas $\left(\mathrm{P}, \mathrm{pl} / \mathrm{m}^{2}\right)$ como variáveis independentes, através da seguinte equação:

$$
V r=a \cdot \mathrm{e}^{-\mathrm{e}^{\frac{-D r+b}{c}}}+d \cdot \mathrm{e}^{\frac{-P+\hbar}{f}}+g \cdot \mathrm{e}^{-\frac{-e^{-x+b}}{c}} \cdot \mathrm{e}^{-\frac{-P+k}{f}}
$$

em que $a(1 / h a), b, c, d(1 / h a), f, g$ (1/ha) e $k$ se referem aos parâmetros empíricos do modelo, determinados através da análise de regressão não linear, minimizando a soma dos quadrados dos desvios.

O modelo estatístico para fins de manejo propõe a utilização do índice de área 
foliar (IAF, $\left.\mathrm{m}^{2} / \mathrm{m}^{2}\right)$, através da seguinte equação:

$$
\operatorname{Vr}=\frac{p I A F}{(q+I A F)}
$$

em que $p$ (l/ha) e $q$ se referem aos parâmetros empíricos do modelo, determinados através da análise de regressão não linear, minimizando a soma dos quadrados dos desvios.

\subsection{O sistema de irrigação}

A irrigação foi feita utilizando o pivô central cujas especificações técnicas estão descritas na Tabela 4.

Tabela 4. Especificações técnicas do equipamento de irrigação.

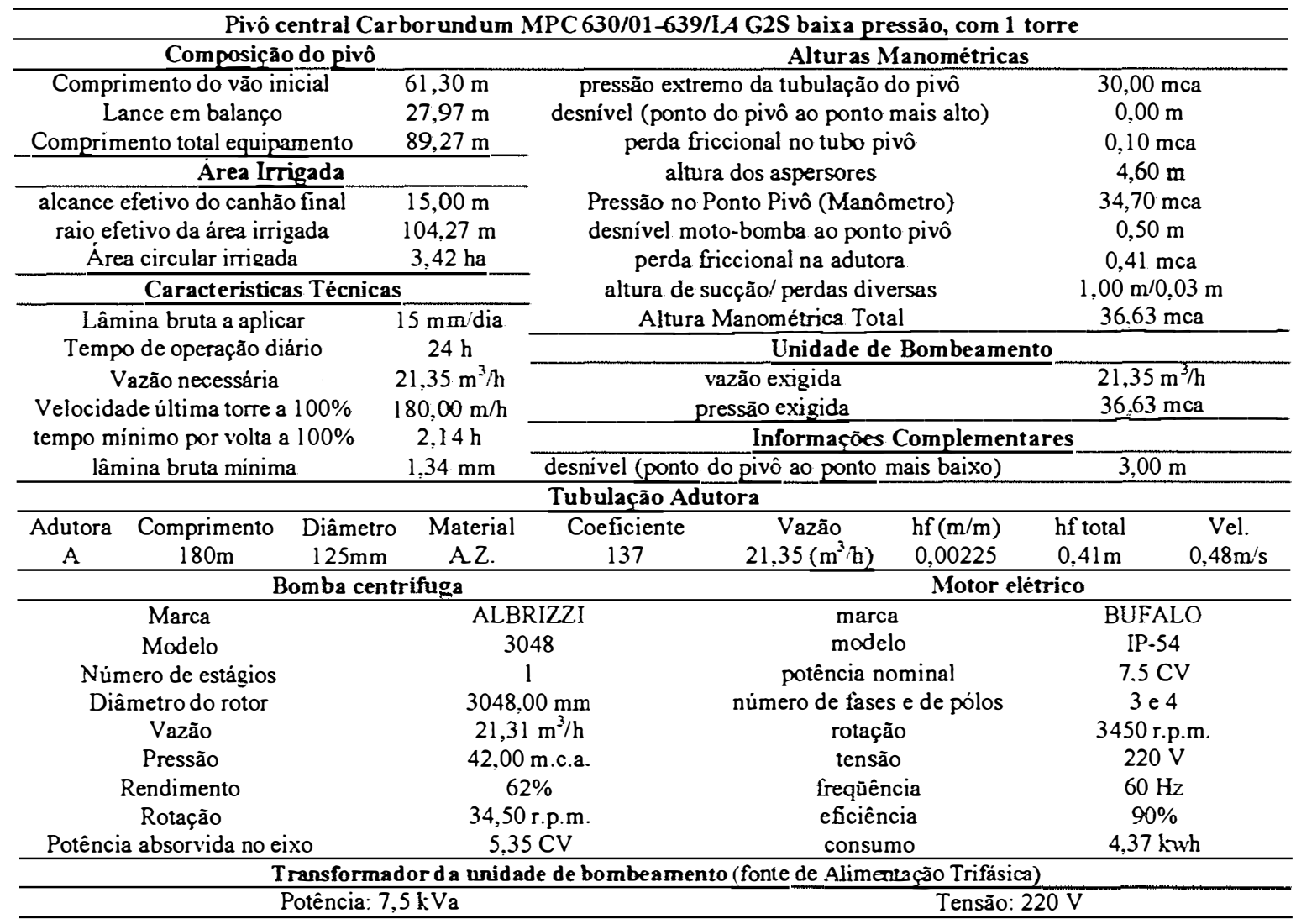




\section{RESULTADOS E DISCUSSÃO}

\subsection{Fenologia da cultura}

Os resultados das observações fenológicas são apresentados na Tabela 5. Cada estádio foi determinado quando $50 \%$ das plantas apresentaram a característica préestabelecida.

Tabela 5. Resultados das observações fenológicas.

\begin{tabular}{clcc}
\hline Id & \multicolumn{1}{c}{ Estádio } & DAE $^{1}$ & Data \\
\hline & Semeadura & -1 & $27 / 8 / 98$ \\
\hline 1 & Emergência & 0 & $7 / 09$ \\
2 & 8 folhas totalmente desdobradas & 20 & $27 / 9$ \\
3 & 12 folhas totalmente desdobradas & 42 & $19 / 10$ \\
4 & Emissão do pendão & 55 & $1 / 11$ \\
5 & Florescimento & 64 & $10 / 11$ \\
6 & Grãos leitosos & 68 & $14 / 11$ \\
7 & Grãos pastosos & 77 & $23 / 11$ \\
$8^{2} / 9$ & Grãos duros & 90 & $6 / 12$ \\
9 & Ponto de maturidade fisiológica & 109 & $25 / 12$ \\
\hline
\end{tabular}

1 dias após emergência

2 estádio não determinado

Foi utilizada a fenologia para caracterizar as épocas de amostragem no intuito de fornecer uma informação mais exata e precisa, o que está de acordo com o que afirmaram Goodmann \& Smith (1978).

\subsection{Desenvolvimento relativo da cultura}

Os resultados do desenvolvimento relativo são apresentados na Tabela 6, Tabela 7, Tabela 8 e Tabela 9. 
Tabela 6. Temperaturas máxima $\left(\mathrm{T}_{1},{ }^{\circ} \mathrm{C}\right)$ e mínima $\left(\mathrm{T}_{2},{ }^{\circ} \mathrm{C}\right)$ do ar, número de graus-dia no (GDi, ${ }^{\circ} \mathrm{C}$.dia) e até (GDAi, ${ }^{\circ} \mathrm{C}$.dia) 0 í-ésimo dia após a emergência, estádio fenológico, número de dias após a emergência (DAE) e desenvolvimento relativo da cultura (Dr) de milho desde a emergência ( 7 de setembro) até 5 folhas (7 de outubro). Departamento de Produção Vegetal, ESALQ, Universidade de São Paulo. Data da semeadura: 27 de agosto de 1998. Data de colheita: 21 de janeiro de 1999.

\begin{tabular}{|c|c|c|c|c|c|c|c|}
\hline Data & $T_{1}$ & $\mathrm{~T}_{2}$ & GDi & GDAi & Estádio & DAE & Dr \\
\hline $7 / 9 / 98$ & 26,5 & 15,4 & 11,0 & 11,0 & Emergência & $\underline{0}$ & $\underline{0,00}$ \\
\hline $8 / 9$ & $\overline{24,6}$ & $\overline{17,7}$ & $\overline{11,2}$ & $\overline{22,2}$ & 0 folha & $\overline{1}$ & $\overline{0,01}$ \\
\hline $9 / 9$ & 25,6 & 16,1 & 10,9 & 33,1 & 0 folha & 2 & 0,02 \\
\hline $10 / 9$ & 25,7 & 13,8 & 9,8 & 42,9 & 0 folha & 3 & 0,03 \\
\hline $11 / 9$ & 32,1 & 13,6 & 12,9 & 55,8 & 0 folha & 4 & 0,04 \\
\hline $12 / 9$ & 32,9 & 17,2 & 15,1 & 70,9 & 1 folha & 5 & 0,04 \\
\hline $13 / 9$ & 33,1 & 17,2 & 15,2 & 86,1 & 1 folha & 6 & 0,05 \\
\hline $14 / 9$ & 28,9 & 17,3 & 13,1 & 99,2 & 1 folha & 7 & 0,06 \\
\hline $15 / 9$ & 28,6 & 15,1 & 11,9 & 111,1 & 1 folha & 8 & 0,07 \\
\hline $16 / 9$ & 29,0 & 15,0 & 12,0 & 123,1 & 1 folha & 9 & 0,08 \\
\hline $17 / 9$ & 35,6 & 14,3 & 15,0 & 138,1 & 2 folhas & 10 & 0,09 \\
\hline $38 / 9$ & 31,9 & 17,9 & 14,9 & 153,0 & 2 folhas & 11 & 0,10 \\
\hline $19 / 9$ & 25,9 & 17,0 & 11,5 & 164,5 & 2 folhas & 12 & 0,10 \\
\hline $20 / 9$ & 23,3 & 15,5 & 9,4 & 173,9 & 2 folhas & 13 & 0,11 \\
\hline $21 / 9$ & 24,8 & 14,8 & 9,8 & 183,7 & 2 folhas & 14 & 0,12 \\
\hline $22 / 9$ & 23,8 & 12,1 & 8,0 & 191,7 & 3 folhas & 15 & 0,12 \\
\hline $23 / 9$ & 26,0 & 13,1 & 9,6 & 201,3 & 3 folhas & 16 & 0,13 \\
\hline $24 / 9$ & 30,8 & 11,9 & 11,4 & 212,7 & 3 folhas & 17 & 0,13 \\
\hline $25 / 9$ & 30,1 & 14,8 & 12,5 & 225,2 & 3 folhas & 18 & 0,14 \\
\hline $26 / 9$ & 30,2 & 15,0 & 12,6 & 237,8 & 3 folhas & 19 & 0,15 \\
\hline $27 / 9$ & 31,2 & 18,0 & 14,6 & 252,4 & 4 folhas & 20 & 0,16 \\
\hline $28 / 9$ & 22,4 & 18,2 & 10,3 & 262,7 & 4 folhas & 21 & 0,17 \\
\hline $29 / 9$ & 22,5 & 18,8 & 10,7 & 273,4 & 4 folhas & 22 & 0,17 \\
\hline $30 / 9$ & 23,7 & 17,0 & 10,4 & 283,8 & 4 folhas & 23 & 0,18 \\
\hline $1 / 10$ & 26,0 & 17,1 & 11,6 & 295,4 & 4 folhas & 24 & 0,19 \\
\hline $2 / 10^{1}$ & 27,1 & 14,8 & 11,0 & 306,4 & 4 folhas & 25 & 0,19 \\
\hline $3 / 10$ & 29,9 & 14,7 & 12,3 & 318,7 & 4 folhas & 26 & 0,20 \\
\hline $4 / 10$ & 32,2 & 16,1 & 14,2 & 332,9 & 5 folhas & 27 & 0,21 \\
\hline $5 / 10$ & 23,0 & 18,8 & 10,9 & 343,8 & 5 folhas & 28 & 0,22 \\
\hline $6 / 10^{1}$ & 28,6 & 15,3 & 12,0 & 355,8 & 5 folhas & 29 & 0,22 \\
\hline $7 / 10$ & 22,9 & 17,1 & 10,0 & 365,8 & 5 folhas & 30 & 0,23 \\
\hline
\end{tabular}

1 Primeira amostragem 
Tabela 7. Temperaturas máxima $\left(\mathrm{T}_{1},{ }^{\circ} \mathrm{C}\right)$ e mínima $\left(\mathrm{T}_{2},{ }^{\circ} \mathrm{C}\right)$ do ar, número de graus-dia no (GDi, ${ }^{\circ} \mathrm{C}$.dia) e até (GDAi, ${ }^{\circ} \mathrm{C}$.dia) o í-ésimo dia após a emergência, estádio fenológico, número de dias após a emergência (DAE) e desenvolvimento relativo da cultura (Dr) de milho desde 5 folhas (8 de outubro) até 13 folhas (5 de novembro). Departamento de Produção Vegetal, ESALQ, Universidade de São Paulo. Data da semeadura: 27 de agosto de 1998. Data de colheita: 21 de janeiro de 1999.

\begin{tabular}{ccccclcc}
\hline Data & $\mathrm{T}_{1}$ & $\mathrm{~T}_{2}$ & GDi & GDAi & Estádio & DAE & Dr \\
\hline $8 / 10$ & 27,3 & 17,2 & 12,3 & 378,1 & 5 folhas & 31 & 0,24 \\
$9 / 10$ & 24,4 & 17,8 & 11,1 & 389,2 & 5 folhas & 32 & 0,25 \\
$10 / 10$ & 26,9 & 13,4 & 10,2 & 399,4 & 6 folhas & 33 & 0,25 \\
$11 / 10$ & 20,3 & 13,5 & 6,9 & 406,3 & 6 folhas & 34 & 0,26 \\
$12 / 10$ & 26,0 & 16,2 & 11,1 & 417,4 & 6 folhas & 35 & 0,26 \\
$13 / 10$ & 28,9 & 17,5 & 13,2 & 430,6 & 6 folhas & 36 & 0,27 \\
$14 / 10$ & 30,8 & 15,9 & 13,4 & 444,0 & 6 folhas & 37 & 0,28 \\
$15 / 10$ & 33,1 & 14,8 & 14,0 & 458,0 & 7 folhas & 38 & 0,29 \\
$16 / 10$ & 24,2 & 17,6 & 10,9 & 468,9 & 7 folhas & 39 & 0,30 \\
$17 / 10$ & 26,0 & 17,3 & 11,7 & 480,6 & 7 folhas & 40 & 0,30 \\
$18 / 10$ & 22,5 & 15,8 & 9,2 & 489,8 & 7 folhas & 41 & 0,31 \\
$19 / 10$ & 27,7 & 13,7 & 10,7 & 500,5 & 8 folhas & 42 & 0,32 \\
$20 / 101$ & 29,9 & 15,7 & 12,8 & 513,3 & 8 folhas & 43 & 0,32 \\
$21 / 10$ & 31,5 & 15,6 & 13,6 & 526,9 & 8 folhas & 44 & 0,33 \\
$22 / 10$ & 31,2 & 15,0 & 13,1 & 540,0 & 8 folhas & 45 & 0,34 \\
$23 / 10$ & 32,4 & 17,5 & 15,0 & 555,0 & 9 folhas & 46 & 0,35 \\
$24 / 10$ & 26,2 & 18,2 & 12,2 & 567,2 & 9 folhas & 47 & 0,36 \\
$25 / 10$ & 28,9 & 17,4 & 13,2 & 580,4 & 9 folhas & 48 & 0,37 \\
$26 / 10$ & 24,4 & 17,7 & 11,1 & 591,5 & 10 folhas & 49 & 0,37 \\
$27 / 10$ & 23,6 & 17,0 & 10,3 & 601,8 & 10 folhas & 50 & 0,38 \\
$28 / 10$ & 28,9 & 18,4 & 13,7 & 615,5 & 10 folhas & 51 & 0,39 \\
$29 / 10$ & 31,4 & 16,6 & 14,0 & 629,5 & 11 folhas & 52 & 0,40 \\
$30 / 10$ & 20,5 & 17,4 & 9,0 & 638,5 & 11 folhas & 53 & 0,40 \\
$31 / 10$ & 22,1 & 15,2 & 8,7 & 647,2 & 11 folhas & 54 & 0,41 \\
$1 / 11$ & 26,8 & 14,2 & 10,5 & 657,7 & 12 folhas & 55 & 0,42 \\
$2 / 11$ & 26,8 & 14,1 & 10,5 & 668,2 & 12 folhas & 56 & 0,42 \\
$3 / 11$ & 25,2 & 14,8 & 10,0 & 678,2 & 12 folhas & 57 & 0,43 \\
$4 / 11$ & 29,5 & 12,2 & 10,9 & 689,1 & 13 folhas & 58 & 0,44 \\
$5 / 11$ & 32,3 & 16,0 & 14,2 & 703,3 & 13 folhas & 59 & 0,44 \\
\hline
\end{tabular}

I Segunda amostragem 
Tabela 8. Temperaturas máxima $\left(T_{1},{ }^{\circ} \mathrm{C}\right)$ e mínima $\left(T_{2},{ }^{\circ} \mathrm{C}\right)$ do ar, número de graus-dia no (GDi, ${ }^{\circ} \mathrm{C}$.dia) e até (GDAi, ${ }^{\circ} \mathrm{C}$.dia) 0 í-ésimo dia após a emergência, estádio fenológico, número de dias após a emergência (DAE) e desenvolvimento relativo da cultura (Dr) de milho desde 13 folhas (6 de novembro) até grão pastoso (6 de dezembro). Departamento de Produção Vegetal, ESALQ, Universidade de São Paulo. Data da semeadura: 27 de agosto de 1998. Data de colheita: 21 de janeiro de 1999.

\begin{tabular}{|c|c|c|c|c|c|c|c|}
\hline Data & $T_{1}$ & $T_{2}$ & GDi & GDAi & Estádio & DAE & $\mathrm{Dr}$ \\
\hline $6 / 11$ & 32,9 & 17,0 & 15,0 & 718,3 & 13 folhas & 60 & 0,45 \\
\hline $7 / 11^{1}$ & 32,9 & 16,4 & 14,7 & 733,0 & 14 folhas & 61 & 0,46 \\
\hline $8 / 11^{1}$ & 31,9 & 18,5 & 15,2 & 748,2 & 14 folhas & 62 & 0,47 \\
\hline $9 / 11$ & 31,9 & 17,6 & 14,8 & 763,0 & 14 folhas & 63 & 0,48 \\
\hline $10 / 11$ & 23,6 & 17,6 & 10,6 & 773,6 & Pendão & 64 & 0,49 \\
\hline $11 / 11$ & 24,2 & 18,0 & 11,1 & 784,7 & Pendão & 65 & 0,50 \\
\hline $12 / 11$ & 29,4 & 14,7 & 12,1 & 796,8 & Pendão & 66 & 0,50 \\
\hline $13 / 11$ & 25,5 & 15,4 & 10,5 & 807,3 & Pendão & 67 & 0,51 \\
\hline $14 / 11$ & 28,4 & 15,9 & 12,2 & 819,5 & Florescimento & 68 & 0,52 \\
\hline $15 / 11$ & 29,6 & 15,7 & 12,7 & 832,2 & Florescimento & 69 & 0,53 \\
\hline $16 / 11$ & 33,2 & 15,9 & 14,6 & 846,8 & Florescimento & 70 & 0,53 \\
\hline $17 / 11$ & 34,0 & 19,2 & 16,6 & 863,4 & Florescimento & 71 & 0,55 \\
\hline $18 / 11$ & 32,8 & 19,7 & 16,3 & 879,7 & Florescimento & 72 & 0,56 \\
\hline 19/11 & 26,3 & 17,6 & 12,0 & 891,7 & Florescimento & 73 & 0,56 \\
\hline $20 / 11$ & 28,8 & 13,8 & 11,3 & 903,0 & Florescimento & 74 & 0,57 \\
\hline $21 / 11$ & 29,6 & 13,6 & 11,6 & 914,6 & Florescimento & 75 & 0,58 \\
\hline $22 / 11$ & 28,9 & 16,1 & 12,5 & 927,1 & Florescimento & 76 & 0,59 \\
\hline $23 / 11$ & 30,8 & 14,4 & 12,6 & 939,7 & Grão leitoso & 77 & 0,59 \\
\hline $24 / 11$ & 34,0 & 14,2 & 14,1 & 953,8 & Grão leitoso & 78 & 0,60 \\
\hline $25 / 11$ & 35,0 & 17,6 & 16,3 & 970,1 & Grão leitoso & 79 & 0,61 \\
\hline $26 / 11$ & 32,8 & 20,2 & 16,5 & 986,6 & Grão leitoso & 80 & 0,62 \\
\hline $27 / 11$ & 26,2 & 20,4 & 13,3 & 999,9 & GTão leitoso & 81 & 0,63 \\
\hline $28 / 11$ & 31,6 & 17,4 & 14,5 & 1014,4 & Grão leitoso & 82 & 0,64 \\
\hline 29/11 & 33,1 & 17,5 & 15,3 & 1029,7 & Grão leitoso & 83 & 0,65 \\
\hline $30 / 11$ & 33,2 & 17,7 & 15,5 & 1045,2 & Grão leitoso & 84 & 0,66 \\
\hline $01 / 12$ & 34,2 & 16,8 & 15,5 & 1060,7 & Grão leitoso & 85 & 0,67 \\
\hline $02 / 12$ & 35,0 & 18,0 & 16,5 & 1077,2 & Grão leitoso & 86 & 0,68 \\
\hline $03 / 12$ & 36,2 & 19,4 & 17,8 & 1095,0 & Grão leitoso & 87 & 0,69 \\
\hline $04 / 12$ & 29,6 & 20,1 & 14,9 & 1109,9 & Grão leitoso & 88 & 0,70 \\
\hline $05 / 12$ & 24,3 & 19,9 & 12,1 & 1122,0 & Grão leitoso & 89 & 0,71 \\
\hline $06 / 12$ & 29,8 & 19,9 & 14,9 & 1136,8 & Grão pastoso & 90 & 0,72 \\
\hline
\end{tabular}


Tabela 9. Temperaturas máxima $\left(T_{1},{ }^{\circ} \mathrm{C}\right)$ e mínima $\left(T_{2},{ }^{\circ} \mathrm{C}\right)$ do ar, número de graus-dia no (GDi, ${ }^{\circ} \mathrm{C}$.dia) e até (GDAi, ${ }^{\circ} \mathrm{C}$.dia) 0 í-ésimo dia após a emergência, estádio fenológico, número de dias após a emergência (DAE) e desenvolvimento relativo da cultura (Dr) de milho desde grão pastoso ( 7 de dezembro) até o ponto de maturidade (6 de janeiro). Departamento de Produção Vegetal, ESALQ, Universidade de São Paulo. Data da semeadura: 27 de agosto de 1998. Data de colheita: 21 de janeiro de 1999.

\begin{tabular}{cccccccc}
\hline DATA & $\mathrm{T}_{1}$ & $\mathrm{~T}_{2}$ & $\mathrm{GDi}$ & $\mathrm{GDAi}$ & Estádio & DAE & Dr \\
\hline $07 / 12$ & 31,0 & 18,5 & 14,8 & 1151,6 & Grão pastoso & 91 & 0,73 \\
$08 / 12$ & 33,9 & 18,4 & 16,2 & 1167,7 & Grão pastoso & 92 & 0,74 \\
$09 / 12$ & 33,7 & 22,4 & 18,1 & 1185,8 & Grão pastoso & 93 & 0,75 \\
$10 / 12$ & 31,1 & 20,3 & 15,7 & 1201,5 & Grão pastoso & 94 & 0,76 \\
$11 / 12$ & 27,0 & 20,4 & 13,7 & 1215,2 & Grão pastoso & 95 & 0,77 \\
$12 / 12$ & 30,4 & 21,6 & 16,0 & 1231,2 & Grão pastoso & 96 & 0,78 \\
$13 / 12$ & 33,3 & 19,3 & 16,3 & 1247,5 & Grão pastoso & 97 & 0,79 \\
$14 / 12$ & 33,1 & 20,9 & 17,0 & 1264,5 & Grão pastoso & 98 & 0,80 \\
$15 / 12$ & 28,5 & 20,0 & 14,3 & 1278,7 & Grão pastoso & 99 & 0,81 \\
$16 / 12$ & 31,1 & 20,4 & 15,8 & 1294,5 & Grão pastoso & 100 & 0,82 \\
$17 / 12$ & 25,8 & 21,2 & 13,5 & 1308,0 & Grão pastoso & 101 & 0,83 \\
$18 / 12$ & 27,6 & 20,8 & 14,2 & 1322,2 & Grão pastoso & 102 & 0,83 \\
$19 / 12$ & 29,2 & 15,6 & 12,4 & 1334,6 & Grão pastoso & 103 & 0,84 \\
$20 / 12$ & 31,3 & 16,6 & 14,0 & 1348,5 & Grão duro & 104 & 0,85 \\
$21 / 12$ & 34,6 & 17,4 & 16,0 & 1364,5 & Grão duro & 105 & 0,86 \\
$22 / 12$ & 28,8 & 20,8 & 14,8 & 1379,3 & Grão duro & 106 & 0,87 \\
$23 / 12$ & 25,1 & 18,6 & 11,9 & 1391,2 & Grão duro & 107 & 0,88 \\
$24 / 12$ & 24,2 & 18,1 & 11,2 & 1402,3 & Grão duro & 108 & 0,89 \\
$25 / 12$ & 23,6 & 19,1 & 11,4 & 1413,7 & Grão duro & 109 & 0,89 \\
$26 / 12$ & 29,4 & 18,9 & 14,2 & 1427,8 & Grão duro & 110 & 0,90 \\
$27 / 12$ & 28,5 & 16,4 & 12,5 & 1440,3 & Grão duro & 111 & 0,91 \\
$28 / 12$ & 31,9 & 17,2 & 14,6 & 1454,8 & Grão duro & 112 & 0,92 \\
$29 / 12$ & 27,3 & 19,2 & 13,3 & 1468,1 & Grão duro & 113 & 0,93 \\
$30 / 12$ & 29,2 & 20,6 & 14,9 & 1483,0 & Grão duro & 114 & 0,94 \\
$31 / 12$ & 31,5 & 18,6 & 15,1 & 1498,0 & Grão duro & 115 & 0,95 \\
$01 / 1$ & 28,2 & 20,3 & 14,3 & 1512,3 & Grão duro & 116 & 0,95 \\
$02 / 1$ & 27,9 & 20,5 & 14,2 & 1526,5 & Grão duro & 117 & 0,96 \\
$03 / 1$ & 31,1 & 20,7 & 15,9 & 1542,4 & Grão duro & 118 & 0,97 \\
$04 / 1$ & 29,2 & 20,6 & 14,9 & 1557,3 & Grão duro & 119 & 0,98 \\
$05 / 1$ & 29,4 & 21,6 & 15,5 & 1572,8 & Grão duro & 120 & 0,99 \\
$06 / 1$ & 21,8 & $\mathbf{2 0 , 4}$ & $\mathbf{1 1 , 1}$ & $\mathbf{1 5 8 3 , 9}$ & Ponto de maturidade & $\mathbf{1 2 1}$ & $\mathbf{1}, 00$ \\
\hline & & & & & & &
\end{tabular}




\section{3 Índice de área foliar}

\subsubsection{Análise de variância para os dois experimentos}

A análise da variância (teste F) mostra que o efeito da população de plantas e da

época de avaliação sobre o indice de área foliar (IAF, $\mathrm{m}^{2} / \mathrm{m}^{2}$ ) foi altamente significativo $(\alpha=0,01)$ nos experimentos L1 e L2 (Tabela 13 e Tabela 16), o que justifica a utilização desses atributos como variáveis independentes.

O indice de área foliar aumentou com o incremento da população (número total de plantas por hectare) e com o desenvolvimento relativo (representando a variável época de avaliação).

Observou-se, ainda, que a interação população x época foi significativa. Sendo essa causa de variação inerente à natureza do experimento de campo (variabilidade espacial do solo e variabilidade genética entre as plantas amostradas, principalmente). No ANEXO são apresentados os valores médios de IAF para as 3 populações, as 3 épocas de avaliação e para cada combinação população $\mathrm{x}$ época no experimento L1 (Tabela 14 e Tabela 15) e no experimento L2 (Tabela 17 e Tabela 18).

Pelo resultado da análise de variância, justifica-se a estimativa do indice de área foliar em função da população de plantas e do desenvolvimento relativo da cultura.

Pela análise de regressão foi encontrado um modelo que explica a relação funcional do índice de área foliar com o a população de plantas e o desenvolvimento relativo da cultura de milho (Tabela 10 e Figura 7).

A possibilidade de que possa ser estimado o IAF a partir desses dois parâmetros é uma ferramenta para o planejamento da cultura, pois conhecendo-se as características do material genético em relação ao seu desenvolvimento relativo pode-se estimar, para uma determinada população de plantas, o índice de área foliar que apresenta a cultura em um determinado momento, o que permitiria determinar o volume máximo de calda utilizável em quimigação foliar. 
4.3.2 Modelo matemático para estimativa do índice de área foliar

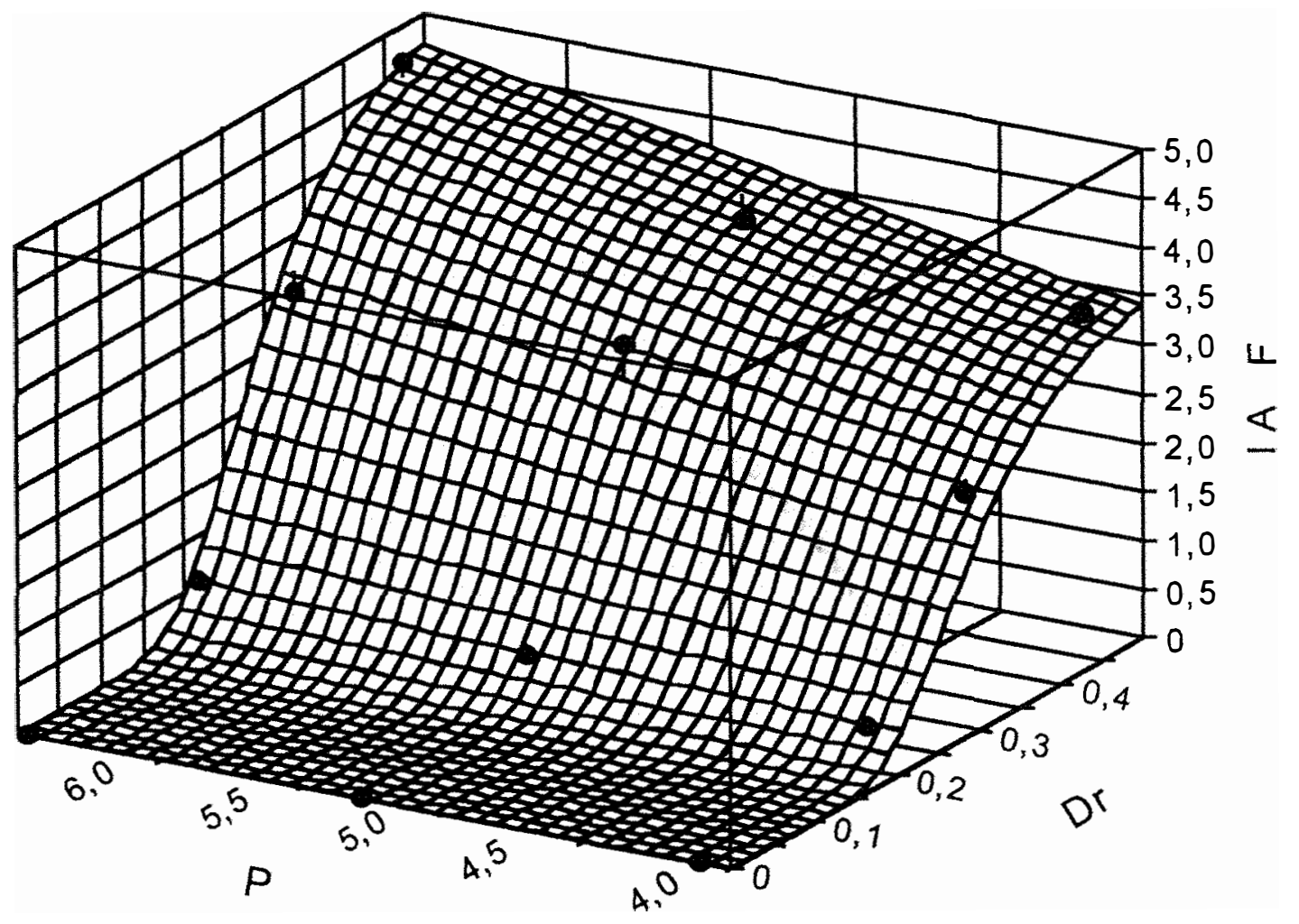

Figura 7. Índice de área foliar (IAF, $\left.\mathrm{m}^{2} / \mathrm{m}^{2}\right)$ em função da população de plantas $(\mathrm{P}$, $\mathrm{pl} / \mathrm{m}^{2}$ ) e do desenvolvimento relativo da cultura (Dr) (Tabela 10). 
Tabela 10. Modelo referente à estimativa do índice de área foliar $\left(\mathrm{IAF}, \mathrm{m}^{2} / \mathrm{m}^{2}\right) \mathrm{em}$ função da população de plantas $\left(\mathrm{P}, \mathrm{pl} / \mathrm{m}^{2}\right)$ e do desenvolvimento relativo da cultura (Dr), com os respectivos valores do coeficiente de correlação (r), número de observações (n), desvio padrão do erro $\left(\mathrm{s}, \mathrm{m}^{2} / \mathrm{m}^{2}\right)$, e valor F (Figura 7).

\begin{tabular}{|c|c|c|c|}
\hline \multicolumn{4}{|c|}{$I A F=a^{\prime} \cdot \mathrm{e}^{-\mathrm{e}^{\frac{-D r+b^{\prime}}{c^{\prime}}}}+d^{\prime} \cdot \mathrm{e}^{\frac{-P+k^{\prime}}{f^{\prime}}}+g^{\prime} \cdot \mathrm{e}^{-\frac{\frac{-D r+b^{\prime}}{c^{\prime}}}{c^{\prime}}} \cdot \mathrm{e}^{-\mathrm{e}^{\frac{-P+k^{\prime}}{S^{\prime}}}}$} \\
\hline \multicolumn{2}{|c|}{ Parâmetros do modelo } & \multicolumn{2}{|c|}{ Parâmetros estatísticos } \\
\hline $\mathrm{a}^{\prime}$ & 3,122111 & $r$ & $0,996 * *$ \\
\hline$b^{\prime}$ & 0,260212 & $\mathrm{n}$ & 18 \\
\hline$c^{\prime}$ & 0,073756 & $S$ & 0,2174 \\
\hline$d^{\prime}$ & 0,002427 & $\mathrm{~F}$ & $116,156^{* *}$ \\
\hline $\mathrm{k}^{\prime}$ & 5,208344 & & \\
\hline $\mathrm{f}^{\prime}$ & 1,825842 & & \\
\hline$g^{\prime}$ & 2,881399 & & \\
\hline
\end{tabular}

** Significativo ao nível de $1 \%$ de probabilidade $\left(\mathrm{r}_{17-0,01}=0,575\right)$

\subsection{Lâmina média retida}

\subsubsection{Análise de variância para os dois experimentos}

A análise da variância para a variável lâmina retida mostra que o efeito da população de plantas não foi significativo, e que o desenvolvimento relativo (representando a variável época de avaliação) foi altamente significativo $(\alpha=0,01)$ no experimento L1 e no experimento L2 (Tabela 19 e Tabela 22).

Observou-se o efeito da interação população x época no experimento L2, devido a lâmina média retida no tratamento "população 2 x época 2 " ter sido superior ao tratamento "população 3 x época 2". Porém, não houve diferença significativa, sendo os valores médios de $0,0608 \mathrm{~mm}$ e de $0,0555 \mathrm{~mm}$, respectivamente.

Esperava-se que a população 3 (maior população) apresentasse, na mesma época de amostragem, uma maior lâmina retida do que a população 2 , devido à expectativa de uma maior área foliar total. No ANEXO são apresentados os valores 
médios da lâmina retida para as 3 populações, 3 épocas de avaliação e para cada combinação população x época no experimento L1 (Tabela 20 e Tabela 21) e no experimento L2 (Tabela 23 e Tabela 24). Essas variações também podem ser explicadas pela natureza do experimento de campo.

Sendo assim, justifica-se pelo resultado da análise de variância e que a lâmina retida nas folhas é função do desenvolvimento relativo da cultura. Isso ocorre porque a medida em que a cultura apresenta maior indice de área foliar, maior é a sua capacidade de reter água. Isso não seria esperado se as folhas da cultura representassem uma área horizontal homogênea que interceptaria uma lâmina de água constante. Porém, devido à arquitetura de parte aérea, as plantas de milho a medida em que crescem e se desenvolvem, produzem um efeito "funil" armazenando água na inserção da folha no colmo na altura da bainha, tal como foi observado também por Stone et al. (1994) e Girardin (1992).

\subsubsection{Modelo matemático para estimativa da lâmina média retida}

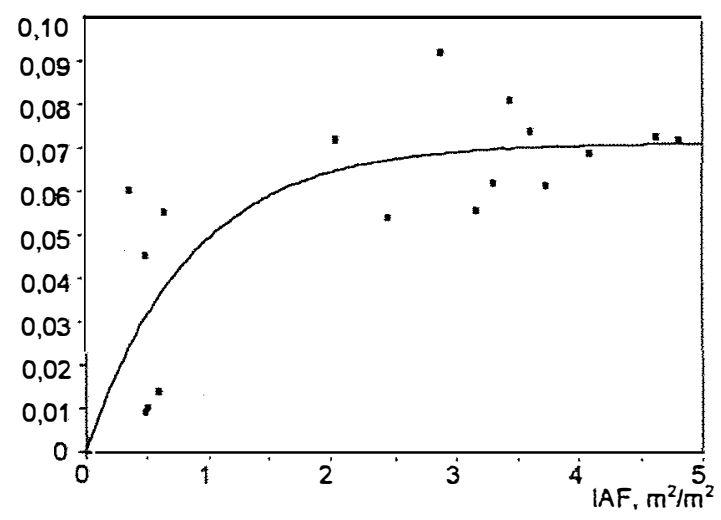

Figura 8. Lâmina retida $(\mathrm{h}, \mathrm{mm})$ em função do índice de área foliar (IAF, $\mathrm{m}^{2} / \mathrm{m}^{2}$ ) (Tabela 11). 


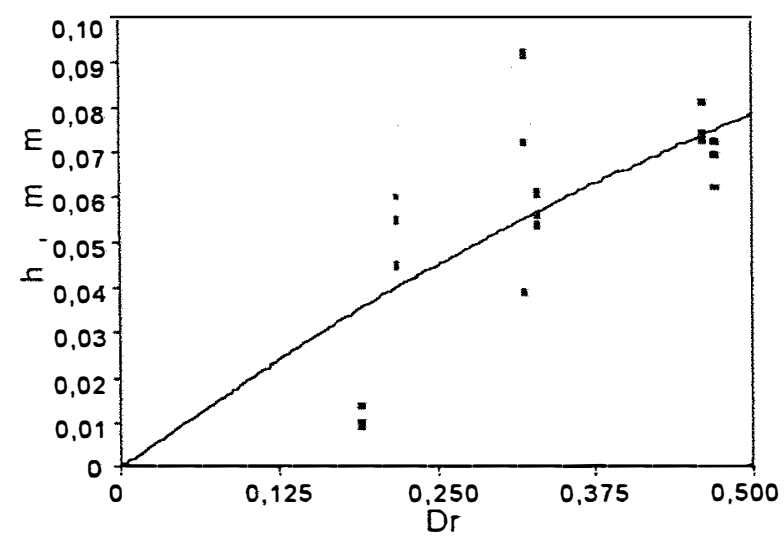

Figura 9. Lâmina retida $(\mathrm{h}, \mathrm{mm})$ em função do desenvolvimento relativo da cultura (Dr) (Tabela 11).

Tabela 11. Modelos referentes à estimativa da lâmina média retida $(\mathrm{h}, \mathrm{mm})$ em função do índice de área foliar (IAF, $\mathrm{m}^{2} / \mathrm{m}^{2}$ ) e do desenvolvimento relativo da cultura (Dr), com os respectivos valores do coeficiente de correlação (r), número de observações (n), desvio padrão do erro (s, $\mathrm{mm})$, e valor $\mathbf{F}$.

\begin{tabular}{|c|c|c|c|c|c|}
\hline \multicolumn{6}{|c|}{$h=u\left(1-\mathrm{e}^{-v \cdot I A F}\right)$ (Referência: manejo $)^{1}$} \\
\hline \multicolumn{2}{|c|}{ Parâmetros do modelo } & \multicolumn{4}{|c|}{ Parâmetros estatísticos } \\
\hline $\mathrm{u}$ & 0,07133 & $\mathrm{~T}$ & $0,734 * *$ & $\mathrm{~s}$ & 0,01708 \\
\hline v & 1,16694 & $\mathrm{n}$ & 18 & $\mathrm{~F}$ & $17,568 * *$ \\
\hline \multicolumn{6}{|c|}{$h=r^{\prime}\left(1-\mathrm{e}^{-s^{\prime} \cdot D r}\right)$ (Referência: planejamento) ${ }^{2}$} \\
\hline \multicolumn{2}{|c|}{ Parâmetros do modelo } & \multicolumn{4}{|c|}{ Parâmetros estatísticos } \\
\hline$r^{\prime}$ & 0,18446 & $r$ & $0,732 * *$ & $\mathrm{~s}$ & 0,01696 \\
\hline$s^{\prime}$ & 1,11144 & $\mathrm{n}$ & 18 & $F$ & $18,047 * *$ \\
\hline
\end{tabular}

** Significativo ao nível de $1 \%$ de probabilidade $\left(\mathrm{r}_{17-0,01}=0,575\right)$

I Figura 8

2 Figura 9 


\subsection{Volume de água retido por hectare na cultura de milho}

\subsubsection{Análise de variância para os dois experimentos}

A análise de variância (Teste F) e mostra que o volume de água retido ( $\mathrm{Vr}, \mathrm{Vha}$ ) apresentou diferenças significativas $(\alpha=0,01)$ devido ao efeito da população de plantas e do desenvolvimento relativo da cultura (época de avaliação) (Tabela 25 e Tabela 28).

Sendo assim, o volume de água retido na parte aérea das plantas é função do índice de área foliar, que por sua vez é função da população de plantas e do desenvolvimento relativo da cultura. Utiliza-se o índice de área foliar com a finalidade de manejo e a população de plantas e desenvolvimento relativo da cultura com a finalidade de planejamento das ações de manejo.

No ANEXO são apresentados os valores médios de volume de água retido por hectare para as 3 populações, as 3 épocas de avaliação e para cada combinação população x época no experimento Ll (Tabela 26 e Tabela 27) e no experimento L2 (Tabela 29 e Tabela 30).

Fez-se ainda a análise conjunta (Tabela 31, Tabela 32 e Tabela 33) para os dois experimentos, para constatar o efeito da lâmina de irrigação aplicada sobre o volume de água retido na parte aérea das plantas. Constatou-se que tal efeito não foi estatisticamente significativo. Isso mostra que neste estudo a quantidade de água retida nas folhas das plantas foi independente da lâmina de irrigação aplicada, o que confirma a validade da equação proposta em que o volume é apresentado como sendo uma função da lâmina retida e do índice de área foliar (modelo universal) ou função do desenvolvimento relativo e da população de plantas (modelo estatístico - referência: planejamento) ou do índice de área foliar (modelo estatístico - referência: manejo).

Para efeito de planejamento, com os modelos propostos, pode-se estimar o volume de calda máximo ( $\mathrm{Vr}, 1 /$ ha) utilizável na aplicação foliar de um produto químico, para uma dada população de plantas, em um determinado desenvolvimento relativo da cultura de milho (Tabela 12 e Figura 10).

Ao nível de manejo da cultura, quando for necessária a aplicação de um produto químico cujo alvo for as folhas das plantas, o volume utilizável pode ser estimado em 
função do IAF (Tabela 12 e Figura 11). A possibilidade de se estimar o volume de calda máximo que pode ser retido na parte aérea das plantas é uma ferramenta para decidir com que equipamento fazer uma aplicação mais eficiente do produto e se é factível a quimigação.

4.5.2 Modelo matemático para estimativa do volume retido nas folhas das plantas de milho

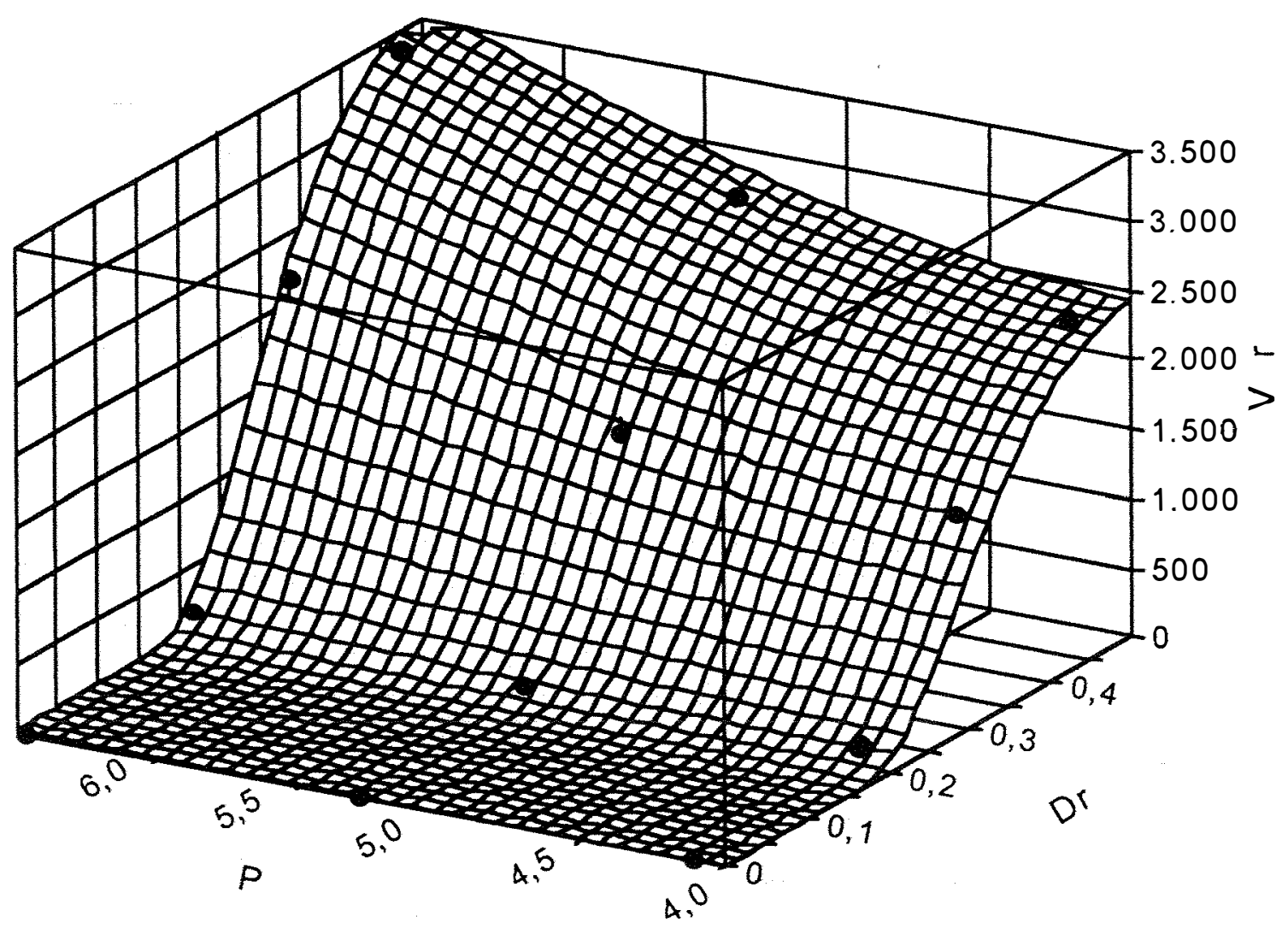

Figura 10. Volume médio retido $(\mathrm{Vr}, \mathrm{l} / \mathrm{ha})$ em função da população de plantas ( $\mathrm{P}$, $\mathrm{pl} / \mathrm{m}^{2}$ ) e do desenvolvimento relativo da cultura (Dr) (Tabela 12) (referência: planejamento). 


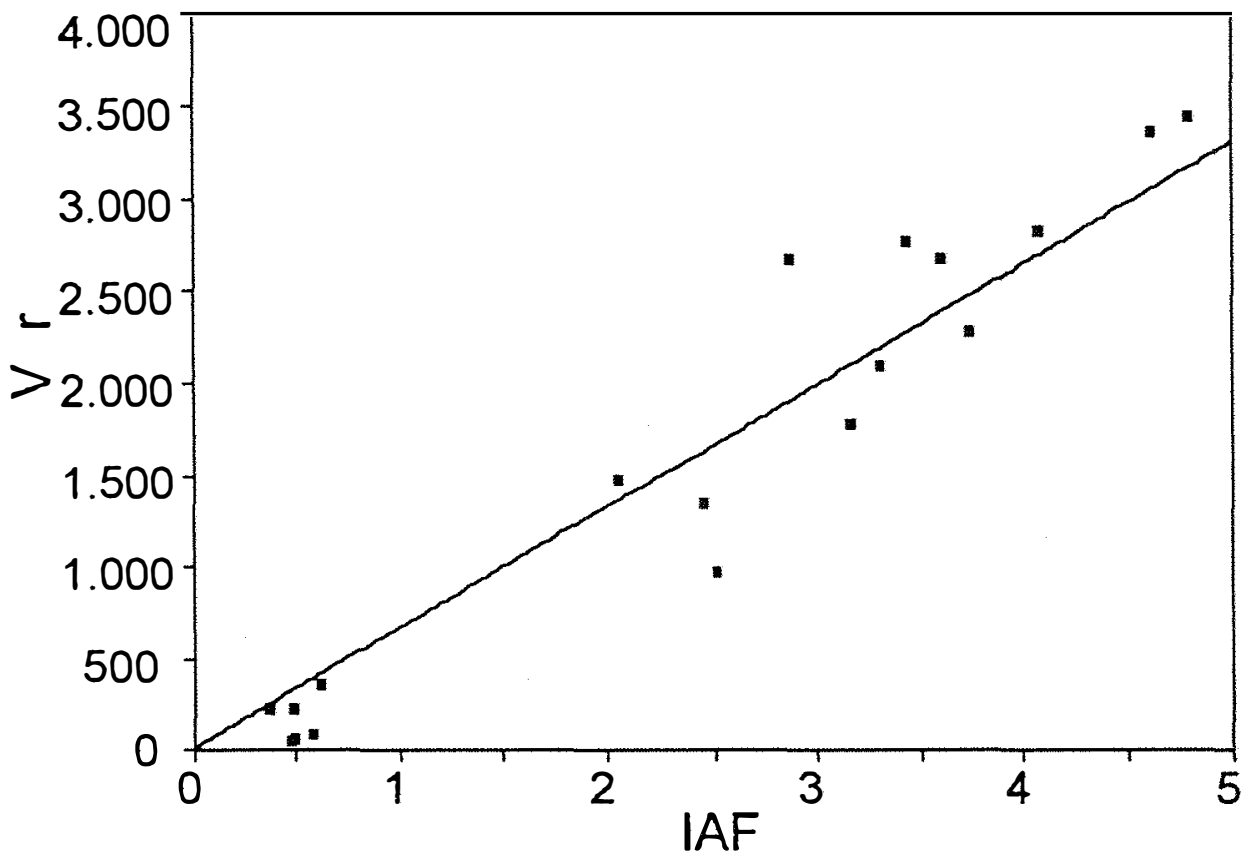

Figura 11. Volume médio retido ( $\mathrm{Vr}, \mathrm{V} / \mathrm{ha}$ ) em função do índice de área foliar (IAF, $\mathrm{m}^{2} / \mathrm{m}^{2}$ ) (Tabela 12) (referência: manejo). 
Tabela 12. Modelos referentes à estimativa do volume de água médio retido ( $\mathrm{Vr}$, Vha) pela cultura de milho em função do índice de área foliar (IAF, $\mathrm{m}^{2} / \mathrm{m}^{2}$ ) (Figura 11) e da população de plantas $\left(\mathrm{pl} / \mathrm{m}^{2}\right)$ e do desenvolvimento relativo da cultura (Dr) (Figura 10), com os respectivos valores do coeficiente de correlação (r), número de observações (n), desvio padrão do erro (s, mm), e valor $\mathrm{F}$.

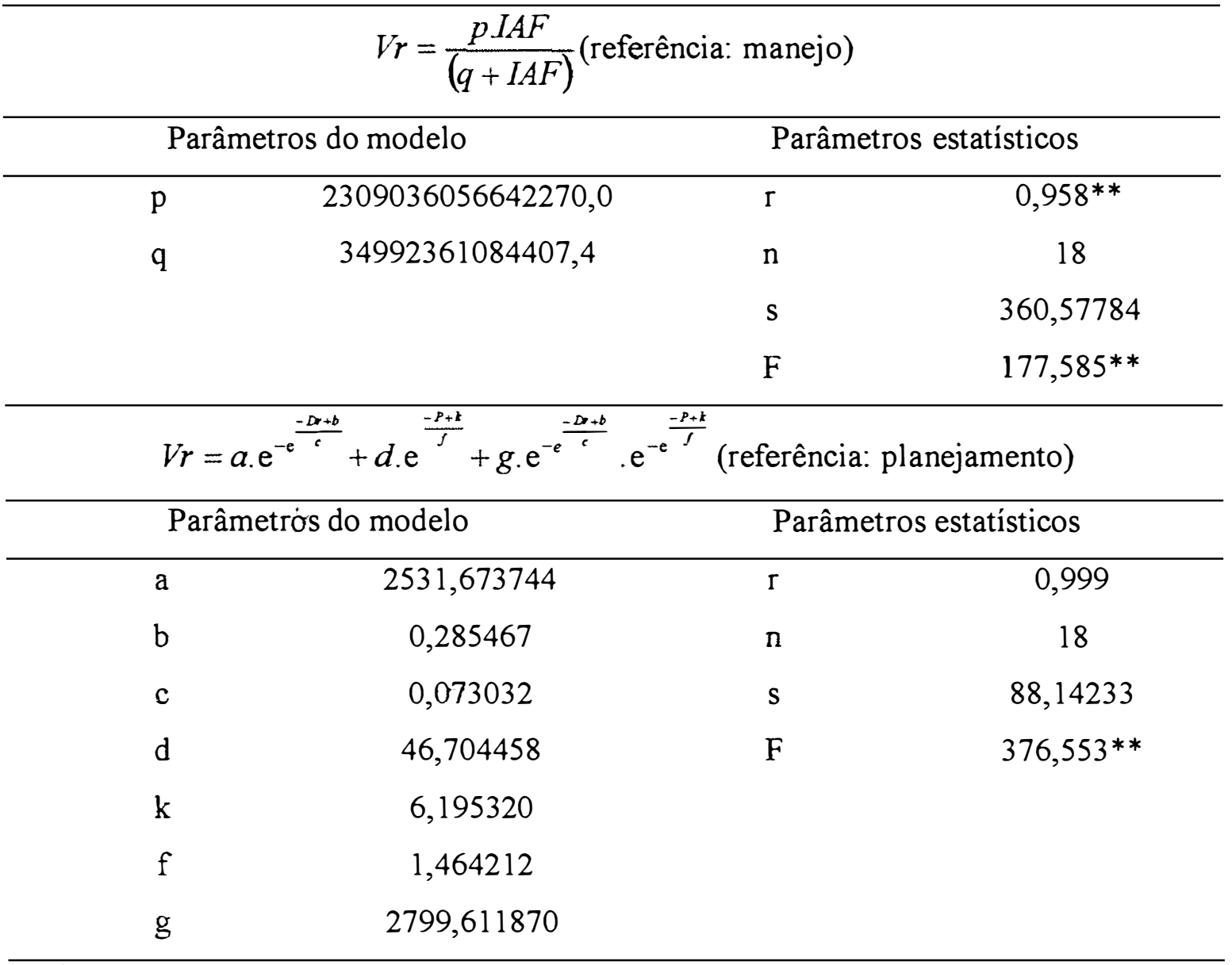

** Significativo ao nivel de $1 \%$ de probabilidade $\left(\mathrm{r}_{17-0,01}=0,575\right)$

1 Figura 11

2 Figura 10

\subsection{Considerações finais}

Pelos resultados apresentados por diferentes autores referentes à determinação da lâmina retida nas folhas das plantas, verifica-se alta variabilidade, provavelmente devido a diferentes metodologias utilizadas para sua determinação. 
É importante ressaltar que apesar da metodologia e dos modelos propostos serem extrapoláveis, salienta-se que os parâmetros determinados no presente trabalho, a rigor, são válidos para as condições em que foi realizado o experimento. Os modelos deveriam ser validados para diferentes materiais genéticos com diferentes arquiteturas de parte aérea em diferentes situações.

Por outro lado, assume-se que a informação de pesquisa é fornecida apenas no intuito de determinar a ordem de grandeza do parâmetro de interesse como uma primeira aproximação, devido à possibilidade de uma infinidade de casos. Nesse caso específico, os modelos universal e estatístico são utilizáveis para estimar (determinar a ordem de grandeza) o volume de calda máximo armazenável nas folhas da cultura de milho, visto que, o acréscimo de outras variáveis implicaria numa maior complexidade do modelo sem ganho na estimativa do valor relativo ao atributo de interesse (nesse caso, volume máximo de calda armazenável nas folhas da cultura de milho).

Sendo assim, o termo modelo universal foi dado devido à possibilidade de sua extrapolação no caso especifico de manejo, assumindo que o valor médio obtido de lâmina retida na primeira época do presente experimento pode ser utilizado na prática para a cultura de milho com até 6 folhas. Após esse estádio, poder-se-ia utilizar o valor médio das lâminas retidas na segunda e terceira épocas, sendo que o índice de área foliar pode ser estimado, nesse caso (referência: manejo), in situ.

Nos demais casos (os diferentes modelos mecanísticos estatísticos contemplando as diferentes combinações possiveis de equações), a rigor, mesmo no modelo universal, há embutidas equações empíricas (equação para estimar o indice de área foliar em função da população e do desenvolvimento relativo, no caso de planejamento; e equação para estimar a lâmina retida em função da população e do desenvolvimento relativo, no caso de planejamento, ou em função do índice de área foliar determinado in situ, no caso de manejo).

A metodologia utilizada foi adequada, porque estima a quantidade de água interceptada e retida nas folhas por diferença de massa, onde o conteúdo de água (água constitutiva) na planta é estimado em função da planta vizinha, o que possibilita uma satisfatória estimativa independentemente da arquitetura de planta, visto que outras metodologias 
que utilizam coletores em diferentes alturas não apresentam a mesma adequação. Por outro lado, a rigor, necessitar-se-ia de uma balança com maior capacidade e maior precisão de medida de massa ${ }^{1}$.

No que diz respeito à questão de escala, salienta-se ainda que, a rigor, o valor estimado do volume retido se refere à cultura, visto que todas as mensurações foram feitas ao nível de planta.

\footnotetext{
'Foi utilizada balança com precisão de $0.01 \mathrm{~g}$
} 


\section{CONCLUSÕES}

De acordo com os resultados obtidos, pode-se concluir que:

i) o índice de área foliar pode ser estimado em função da população de plantas e do desenvolvimento relativo da cultura;

ii) a lâmina média retida pode ser estimada em função do desenvolvimento relativo da cultura;

iii) o volume máximo de calda visando a aplicação foliar de produtos químicos na cultura de milho pode ser estimado, através dos modelos estatísticos, em função do desenvolvimento relativo da cultura e da população, bem como em função do índice de área foliar;

iv) o modelo universal é utilizável para estimar o volume máximo de calda, tanto para fins de planejamento quanto para fins de manejo;

v) os modelos universal e estatístico apresentam estimativas similares. 


\section{ANEXO: Análise estatística}

Tabela 13. Análise de variância relativa ao índice de área foliar (IAF, $\mathrm{m}^{2} / \mathrm{m}^{2}$ ) correspondente ao experimento $L 1$.

\begin{tabular}{lcccc}
\hline Causa da variação & Graus de liberdade & S.Q. & Q.M. & F \\
\hline População (P) & 2 & 3,32655 & 1,66328 & $12,22^{* *}$ \\
Resíduo (a) & 9 & 1,22533 & 0,13615 & \\
\hline (Parcelas) & 11 & & & \\
Época (E) & 2 & 69,42732 & 34,71366 & $569,00 * *$ \\
P x E & 4 & 1,48653 & 0,37163 & $6,09 * *$ \\
Resíduo (b) & 18 & 1,09815 & 0,06101 & \\
\hline Total & 35 & 76,56388 & &
\end{tabular}

** Significativo ao nivel de $1 \%$ de probabilidade $(\alpha=0,01)$

* Significativo ao nível de $5 \%$ de probabilidade $(\alpha=0,05)$

$\mathrm{R}^{2}=0,986, \mathrm{CV}=10,81 \%, \mathrm{~s}=0,247$, média $=2,284$ 
Tabela 14. Valores médios de índice de área foliar (IAF, $\mathrm{m}^{2} / \mathrm{m}^{2}$ ) para cada população $\left(P, \mathrm{pl} / \mathrm{m}^{2}\right)$ e cada época de avaliação (E) e teste de comparação dos valores médios de IAF entre populações e entre épocas no experimento $L 1$.

\begin{tabular}{|c|c|c|c|c|c|}
\hline \multirow[t]{2}{*}{$\bar{P}$} & \multirow[t]{2}{*}{ IAF } & \multicolumn{4}{|c|}{$\operatorname{Pr}>|\mathrm{T}| \mathrm{HO}:$ Média(i)=Média(j) } \\
\hline & & $\mathrm{i} / \mathrm{j}$ & 1 & 2 & 3 \\
\hline 1 & 2,004 & 1 & & & \\
\hline 2 & 2,142 & 2 & 0,3851 & & \\
\hline 3 & 2,707 & 3 & 0,0012 & 0,0045 & \\
\hline \multirow[t]{2}{*}{$\bar{E}$} & IAF & \multicolumn{4}{|c|}{$\operatorname{Pr}>|\mathrm{T}| \mathrm{HO}:$ Média(i)=Média(j) } \\
\hline & & $\mathrm{i} / \mathrm{j}$ & 1 & 2 & 3 \\
\hline 1 & 0,497 & 1 & & & \\
\hline 2 & 2,473 & 2 & 0,0001 & & \\
\hline 3 & 3,883 & 3 & 0,0001 & 0,0001 & \\
\hline Média geral & 2,284 & & & & \\
\hline
\end{tabular}


Tabela 15. Valores médios de índice de área foliar (IAF, $\mathrm{m}^{2} / \mathrm{m}^{2}$ ) para cada combinação população $\left(\mathrm{P}, \mathrm{pl} / \mathrm{m}^{2}\right) \times$ época de avaliação (E) no experimento L1 e teste de comparação dos valores médios de IAF entre os tratamentos $\mathbf{P} \times \mathbf{E}$.

\begin{tabular}{cccc}
\hline P & E & LAF & Número da média \\
\hline 1 & 1 & 0,365 & 1 \\
1 & 2 & 2,045 & 2 \\
1 & 3 & 3,603 & 3 \\
2 & 1 & 0,493 & 4 \\
2 & 2 & 2,505 & 5 \\
2 & 3 & 3,428 & 6 \\
3 & 1 & 0,633 & 7 \\
3 & 2 & 2,870 & 8 \\
3 & 3 & 4,618 & 9 \\
\hline
\end{tabular}

$\operatorname{Pr}>|\mathrm{T}| \mathrm{H} 0:$ Média(i)=Média(j)

\begin{tabular}{|c|c|c|c|c|c|c|c|c|c|}
\hline $\mathrm{i} / \mathrm{j}$ & 1 & 2 & 3 & 4 & 5 & 6 & 7 & 8 & 9 \\
\hline 1 & & & & & & & & & \\
\hline 2 & 0,0001 & & & & & & & & \\
\hline 3 & 0,0001 & 0,0001 & & & & & & & \\
\hline 4 & 0,4748 & 0,0001 & 0,0001 & & & & & & \\
\hline 5 & 0,0001 & 0,0169 & 0,0001 & 0,0001 & & & & & \\
\hline 6 & 0,0001 & 0,0001 & 0,3296 & 0,0001 & 0,0001 & & & & \\
\hline 7 & 0,1430 & 0,0001 & 0,0001 & 0,4332 & 0,0001 & 0,0001 & & & \\
\hline 8 & 0,0001 & 0,0002 & 0,0005 & 0,0001 & 0,0511 & 0,0051 & 0,0001 & & \\
\hline 9 & 0,0001 & 0,0001 & 0,0001 & 0,0001 & 0,0001 & 0,0001 & 0,0001 & 0,0001 & \\
\hline
\end{tabular}


Tabela 16. Análise de variância relativa ao índice de área foliar $\left(\mathrm{IAF}, \mathrm{m}^{2} / \mathrm{m}^{2}\right)$ correspondente ao experimento $L 2$.

\begin{tabular}{lcccc}
\hline Causa da variação & Graus de liberdade & S.Q. & Q.M. & F \\
\hline População (P) & 2 & 4,37162 & 2,18581 & $37,15^{* *}$ \\
Resíduo (a) & 9 & 0,52953 & 0,05884 & \\
\hline (Parcelas) & 11 & & & \\
Época (E) & 2 & 80,67551 & 40,33775 & $1139,90 * *$ \\
P x E & 4 & 3,47133 & 0,86783 & $4,52^{* *}$ \\
Resíduo (b) & 18 & 0,63697 & 0,03539 & \\
\hline Total & 35 & 89,68496 & & \\
\hline
\end{tabular}

** Significativo ao nivel de $1 \%$ de probabilidade $(\alpha=0,01)$

* Significativo ao nivel de $5 \%$ de probabilidade $(\alpha=0,05)$

$\mathrm{R}^{2}=0,9993, \mathrm{CV}=7,32 \%, \mathrm{~s}=0,188$, média $=2,569$

Tabela 17. Valores médios de índice de área foliar (IAF, $\mathrm{m}^{2} / \mathrm{m}^{2}$ ) para cada população $\left(P, \mathrm{pl} / \mathrm{m}^{2}\right)$ e cada época de avaliação (E), e teste de comparação dos valores médios de IAF entre populações e entre épocas no experimento $L 2$.

\begin{tabular}{|c|c|c|c|c|c|}
\hline \multirow[t]{2}{*}{$\mathrm{P}$} & \multirow[t]{2}{*}{ IAF } & \multicolumn{4}{|c|}{$\operatorname{Pr}>|\mathrm{T}|$ H0: Média(i)=Média(j) } \\
\hline & & $\mathrm{i} / \mathrm{j}$ & 1 & 2 & 3 \\
\hline 1 & 2,078 & 1 & & & \\
\hline 2 & 2,773 & 2 & 0,0001 & & \\
\hline 3 & 2,855 & 3 & 0,0001 & 0,4309 & \\
\hline \multirow[t]{2}{*}{$\bar{E}$} & IAF & \multicolumn{4}{|c|}{$\operatorname{Pr}>|\mathrm{T}| \mathrm{H} 0:$ Média(i)=Média(j) } \\
\hline & & $\mathrm{i} / \mathrm{j}$ & 1 & 2 & 3 \\
\hline 1 & 0,523 & 1 & & & \\
\hline 2 & 3,119 & 2 & 0,0001 & & \\
\hline 3 & 4,064 & 3 & 0,0001 & 0,0001 & \\
\hline Média geral & 2,569 & & & & \\
\hline
\end{tabular}


Tabela 18. Valores médios de índice de área foliar (IAF, $\mathrm{m}^{2} / \mathrm{m}^{2}$ ) para cada combinação população $\left(P, \mathrm{pl} / \mathrm{m}^{2}\right) \times$ época de avaliação (E) no experimento L2 e teste de comparação dos valores médios de IAF entre os tratamentos $\mathbf{P} \times \mathbf{E}$.

\begin{tabular}{|c|c|c|c|c|c|c|c|c|}
\hline & \multicolumn{2}{|l|}{$\mathrm{P}$} & \multicolumn{2}{|l|}{$E$} & \multicolumn{2}{|r|}{ IAF } & \multicolumn{2}{|c|}{ Número da média } \\
\hline & \multicolumn{2}{|l|}{1} & \multicolumn{2}{|l|}{1} & \multicolumn{2}{|c|}{0,478} & \multicolumn{2}{|r|}{1} \\
\hline & \multicolumn{2}{|l|}{1} & \multicolumn{2}{|l|}{2} & \multicolumn{2}{|c|}{2,448} & \multicolumn{2}{|r|}{2} \\
\hline & \multicolumn{2}{|l|}{1} & \multicolumn{2}{|l|}{3} & \multicolumn{2}{|c|}{3,310} & \multicolumn{2}{|r|}{3} \\
\hline & \multicolumn{2}{|l|}{2} & \multicolumn{2}{|l|}{1} & \multicolumn{2}{|c|}{0,500} & \multicolumn{2}{|r|}{4} \\
\hline & \multicolumn{2}{|l|}{2} & \multicolumn{2}{|l|}{2} & \multicolumn{2}{|c|}{3,740} & \multicolumn{2}{|r|}{5} \\
\hline & \multicolumn{2}{|l|}{2} & \multicolumn{2}{|l|}{3} & \multicolumn{2}{|c|}{4,080} & \multicolumn{2}{|r|}{6} \\
\hline & \multicolumn{2}{|l|}{3} & \multicolumn{2}{|l|}{1} & \multicolumn{2}{|c|}{0,593} & \multicolumn{2}{|r|}{7} \\
\hline & \multicolumn{2}{|l|}{3} & \multicolumn{2}{|l|}{2} & & 3,170 & & 8 \\
\hline & 3 & & 3 & & & 4,803 & & 9 \\
\hline & & & $\operatorname{Pr}>1 T$ & HO: Mé & $\operatorname{dia}(\mathrm{i})=\mathrm{M}$ & lédia(j) & & \\
\hline $\mathrm{i} / \mathrm{j}$ & 1 & 2 & 3 & 4 & 5 & 6 & 7 & 9 \\
\hline 1 & & & & & & & & \\
\hline 2 & 0,0001 & & & & & & & \\
\hline 3 & 0,0001 & 0,0001 & & & & & & \\
\hline 4 & 0,8676 & 0,0001 & 0,0001 & & & & & \\
\hline 5 & 0,0001 & 0,0001 & 0,0046 & 0,0001 & & & & \\
\hline 6 & 0,0001 & 0,0001 & 0,0001 & 0,0001 & 0,0198 & & & \\
\hline 7 & 0,3987 & 0,0001 & 0,0001 & 0,4957 & 0,0001 & 0,0001 & & \\
\hline 8 & 0,0001 & 0,0001 & 0,3065 & 0,0001 & 0,0004 & 0,0001 & 0,0001 & \\
\hline 9 & 0,0001 & 0,0001 & 0,0001 & 0,0001 & 0,0001 & 0,0001 & 0,0001 & 0,0001 \\
\hline
\end{tabular}


Tabela 19. Análise de variância relativa à lâmina de água retida (h, $\mathrm{mm})$ correspondente ao experimento $\mathrm{L} 1$.

\begin{tabular}{lcccc}
\hline Causa da variação & Graus de liberdade & S.Q. & Q.M. & F \\
\hline População (P) & 2 & 0,00218 & 0,00109 & $2,79^{\text {n.s. }}$ \\
Resíduo (a) & 9 & 0,00352 & 0,00039 & \\
\hline (Parcelas) & 11 & & & \\
Época (E) & 2 & 0,00318 & 0,00159 & $14,25^{*}$ \\
P x E & 4 & 0,00421 & 0,00105 & $9,44^{* *}$ \\
Resíduo (b) & 18 & 0,00201 & 0,00011 & \\
\hline Total & 35 & 0,01510 & &
\end{tabular}

** Significativo ao nivel de $1 \%$ de probabilidade $(\alpha=0,01)$

* Significativo ao nível de $5 \%$ de probabilidade $(\alpha=0,05)$

$\mathrm{R}^{2}=0,867, \mathrm{CV}=16,11 \%, \mathrm{~s}=0,011$, média $=0,0656$

Tabela 20. Valores médios de lâmina de água retida para cada população $\left(\mathrm{P}, \mathrm{pl} / \mathrm{m}^{2}\right)$ e cada época de avaliação (E) e teste de comparação dos valores médios de lâmina de água retida entre populações e entre épocas no experimento $\mathrm{L} 1$.

\begin{tabular}{|c|c|c|c|c|c|}
\hline \multirow[t]{2}{*}{$\mathrm{P}$} & \multirow[t]{2}{*}{$\mathrm{h}(\mathrm{mm})$} & \multicolumn{4}{|c|}{$\operatorname{Pr}>|T|$ H0: Média(i)=Média(j) } \\
\hline & & $i / j$ & 1 & 2 & 3 \\
\hline 1 & 0,0688 & 1 & & & \\
\hline 2 & 0,0548 & 2 & 0,1190 & & \\
\hline 3 & 0,0731 & 3 & 0,6046 & 0,0502 & \\
\hline \multirow[t]{2}{*}{$\mathrm{E}$} & $\mathrm{h}(\mathrm{mm})$ & \multicolumn{4}{|c|}{$\operatorname{Pr}>|T|$ HO: Média(i)=Média(j) } \\
\hline & & $\mathrm{i} / \mathrm{j}$ & 1 & 2 & 3 \\
\hline 1 & 0,0532 & 1 & & & \\
\hline 2 & 0,0676 & 2 & 0,0036 & & \\
\hline 3 & 0,0759 & 3 & 0,0001 & 0,0692 & \\
\hline
\end{tabular}

Média geral 0,0656


Tabela 21. Valores médios de lâmina de água retida para cada combinação população $\left(\mathrm{P}, \mathrm{pl} / \mathrm{m}^{2}\right) \times$ época de avaliação (E) no experimento L1e teste de comparação dos valores médios de lâmina de água retida entre os tratamentos $\mathbf{P} \times \mathbf{E}$.

\begin{tabular}{cccc}
\hline $\mathrm{P}$ & $\mathrm{E}$ & $\mathrm{h}(\mathrm{mm})$ & Número da média \\
\hline 1 & 1 & 0,0600 & 1 \\
1 & 2 & 0,0720 & 2 \\
1 & 3 & 0,0743 & 3 \\
2 & 1 & 0,0450 & 4 \\
2 & 2 & 0,0388 & 5 \\
2 & 3 & 0,0808 & 6 \\
3 & 1 & 0,0545 & 7 \\
3 & 2 & 0,0920 & 8 \\
3 & 3 & 0,0728 & 9 \\
\hline
\end{tabular}

\begin{tabular}{|c|c|c|c|c|c|c|c|c|c|}
\hline \multicolumn{10}{|c|}{ Pr $>|\mathrm{T}| \mathrm{H0}:$ Média(i)=Média(j) } \\
\hline $\mathrm{i} / \mathrm{j}$ & 1 & 2 & 3 & 4 & 5 & 6 & 7 & 8 & 9 \\
\hline 1 & & & & & & & & & \\
\hline 2 & 0,1255 & & & & & & & & \\
\hline 3 & 0,0725 & 0,7667 & & & & & & & \\
\hline 4 & 0,0598 & 0,0020 & 0,0010 & & & & & & \\
\hline 5 & 0,0107 & 0,0003 & 0,0002 & 0,4136 & & & & & \\
\hline 6 & 0,0124 & 0,2566 & 0,3956 & 0,0001 & 0,0001 & & & & \\
\hline 7 & 0,4709 & 0,0308 & 0,0165 & 0,2195 & 0,0492 & 0,0025 & & & \\
\hline 8 & 0,0004 & 0,0154 & 0,0288 & 0,0001 & 0,0001 & 0,1493 & 0,0001 & & \\
\hline 9 & 0,1050 & 0,9211 & 0,8431 & 0,0016 & 0,0002 & 0,2982 & 0,0251 & 0,0190 & \\
\hline
\end{tabular}


Tabela 22. Análise de variância relativa à lâmina de água retida (h, $\mathrm{mm})$ correspondente a experimento $\mathbf{L} 2$.

\begin{tabular}{lcccc}
\hline \multicolumn{1}{c}{ Causa da variação } & Graus de liberdade & S.Q. & Q.M. & F \\
\hline População (P) & 2 & 0,00019 & 0,00009 & $1,29^{\text {n.s. }}$ \\
Resíduo (a) & 9 & 0,00066 & 0,00007 & \\
(Parcelas) & 11 & & & \\
Época (E) & 2 & 0,02192 & 0,01096 & $189,50^{* *}$ \\
P x E & 4 & 0,00014 & 0,00003 & $0,59^{\text {n.s. }}$ \\
Resíduo (b) & 18 & 0,00104 & 0,00006 & \\
\hline Total & 35 & 0,02395 & &
\end{tabular}

** Significativo ao nível de $1 \%$ de probabilidade $(\alpha=0,01)$

* Significativo ao nivel de $5 \%$ de probabilidade $(\alpha=0,05)$

$\mathrm{R}^{2}=0,957, \mathrm{CV}=16,87 \%, \mathrm{~s}=0,008$, média $=0,0451$

Tabela 23. Valores médios de lâmina de água retida para cada população $\left(\mathrm{P}, \mathrm{pl} / \mathrm{m}^{2}\right)$ e cada época de avaliação (E) e teste de comparação dos valores médios de lâmina de água retida entre populações e entre épocas no experimento $\mathbf{L 2}$.

\begin{tabular}{cccccc}
\hline $\mathrm{P}$ & $\mathrm{h}(\mathrm{mm})$ & \multicolumn{4}{c}{$\operatorname{Pr}>|\mathrm{T}| \mathrm{H} 0:$ Média(i)=Média(j) } \\
\cline { 3 - 6 } & & $\mathrm{i} / \mathrm{j}$ & 1 & 2 & 3 \\
\hline 1 & 0,0418 & 1 & & & \\
2 & 0,0466 & 2 & 0,2084 & & \\
3 & 0,0468 & 3 & 0,1875 & 0,9447 & \\
\hline $\mathrm{E}$ & $\mathrm{h}(\mathrm{mm})$ & \multicolumn{4}{c}{$\operatorname{Pr}>|\mathrm{T}| \mathrm{H} 0:$ Média(i)=Média(j) } \\
\cline { 3 - 6 } & & $\mathrm{i} / \mathrm{j}$ & 1 & 2 & \\
\hline 1 & 0,0108 & 1 & & & \\
2 & 0,0568 & 2 & 0,0001 & & \\
3 & 0,0677 & 3 & 0,0001 & 0,0026 & \\
\hline Média geral & 0,0451 & & & & \\
\hline
\end{tabular}


Tabela 24. Valores médios de lâmina de água retida para cada combinação população $\left(\mathrm{P}, \mathrm{pl} / \mathrm{m}^{2}\right)$ época de avaliação (E) no experimento $\mathrm{L} 2$ e teste de comparação dos valores médios de lâmina de água retida entre os tratamentos $\mathbf{P} \times \mathbf{E}$.

\begin{tabular}{|c|c|c|c|c|c|c|c|c|c|}
\hline & \multirow{2}{*}{$\begin{array}{l}\mathrm{P} \\
1\end{array}$} & \multicolumn{3}{|c|}{$E$} & \multicolumn{2}{|c|}{$\mathrm{h}(\mathrm{mm})$} & \multicolumn{3}{|c|}{ Número da média } \\
\hline & & \multicolumn{3}{|c|}{1} & \multicolumn{2}{|c|}{0,0090} & \multicolumn{3}{|c|}{1} \\
\hline & \multicolumn{2}{|l|}{1} & \multicolumn{2}{|l|}{2} & \multicolumn{2}{|c|}{0,0543} & \multicolumn{3}{|c|}{2} \\
\hline & \multicolumn{2}{|l|}{1} & \multicolumn{2}{|l|}{3} & \multicolumn{2}{|c|}{0,0623} & \multicolumn{3}{|c|}{3} \\
\hline & \multicolumn{2}{|l|}{2} & \multicolumn{2}{|l|}{1} & \multicolumn{2}{|c|}{0,0098} & \multicolumn{3}{|c|}{4} \\
\hline & \multicolumn{2}{|l|}{2} & \multicolumn{2}{|l|}{2} & \multicolumn{2}{|c|}{0,0608} & \multicolumn{3}{|c|}{5} \\
\hline & \multicolumn{2}{|l|}{2} & \multicolumn{2}{|l|}{3} & \multicolumn{2}{|c|}{0,0693} & \multicolumn{3}{|c|}{6} \\
\hline & \multicolumn{2}{|l|}{3} & \multicolumn{2}{|l|}{1} & \multicolumn{2}{|c|}{0,0135} & \multicolumn{3}{|c|}{7} \\
\hline & \multicolumn{2}{|l|}{3} & \multicolumn{2}{|l|}{2} & \multicolumn{2}{|c|}{0,0555} & & 8 & \\
\hline & 3 & & 3 & & &, 0715 & & 9 & \\
\hline & & & $\operatorname{Pr}>\mid I$ & HO: Mé & $\operatorname{dia}(i)=M$ & édia(j) & & & \\
\hline $\mathrm{i} / \mathrm{j}$ & 1 & 2 & 3 & 4 & 5 & 6 & 7 & 8 & 9 \\
\hline 1 & & & & & & & & & \\
\hline 2 & 0,0001 & & & & & & & & \\
\hline 3 & 0,0001 & 0,1542 & & & & & & & \\
\hline 4 & 0,8906 & 0,0001 & 0,0001 & & & & & & \\
\hline 5 & 0,0001 & 0,2424 & 0,7835 & 0,0001 & & & & & \\
\hline 6 & 0,0001 & 0,0121 & 0,2095 & 0,0001 & 0,1314 & & & & \\
\hline 7 & 0,4137 & 0,0001 & 0,0001 & 0,4945 & 0,0001 & 0,0001 & & & \\
\hline 8 & 0,0001 & 0,8188 & 0,2255 & 0,0001 & 0,3419 & 0,0198 & 0,0001 & & \\
\hline 9 & 0,0001 & 0,0049 & 0,1026 & 0,0001 & 0,0609 & 0,6806 & 0,0001 & 0,0081 & \\
\hline
\end{tabular}


Tabela 25. Análise de variância relativa ao volume de água retido ( $\mathrm{Vr}, \mathrm{l} / \mathrm{ha}$ ) correspondente ao experimento $L 1$.

\begin{tabular}{lcccc}
\hline Causa da variação & Graus de liberdade & S.Q & Q.M. & F \\
\cline { 1 - 2 } População (P) & 2 & 4526426,78 & 2263213,39 & $11,39^{* *}$ \\
Resíduo (a) & 9 & 1787811,15 & 198645,68 & \\
(Parcelas) & 11 & & & \\
Época (E) & 2 & 42418015,52 & 21209007,76 & $169,01^{* *}$ \\
P x E & 4 & 2777355,66 & 694338,92 & $5,53^{* *}$ \\
Resíduo (b) & 18 & 2258844,17 & 125491,34 & \\
\hline Total & 35 & 53768453,28 & & \\
\hline
\end{tabular}

** Significativo ao nivel de $1 \%$ de probabilidade $(\alpha=0,01)$

* Significativo ao nivel de $5 \%$ de probabilidade $(\alpha=0,05)$

$\mathrm{R}^{2}=0,958, \mathrm{CV}=21,81 \%, \mathrm{~s}=354,248$, média $=1.623,99$

Tabela 26. Valores médios de volume de água retido para cada população $\left(\mathrm{P}, \mathrm{pl} / \mathrm{m}^{2}\right)$ e cada época de avaliação (E) e teste de comparação dos valores médios de volume de água retido entre populações e entre épocas no experimento $L 1$.

\begin{tabular}{|c|c|c|c|c|c|}
\hline \multirow[t]{2}{*}{$\mathrm{P}$} & \multirow[t]{2}{*}{$\operatorname{Vr}(1 / \mathrm{ha})$} & \multicolumn{4}{|c|}{$\operatorname{Pr}>|T|$ H0: Média(i)=Média(j) } \\
\hline & & $\mathrm{i} / \mathrm{j}$ & 1 & 2 & 3 \\
\hline 1 & 1445,01 & 1 & & & \\
\hline 2 & 1307,80 & 2 & 0,4701 & & \\
\hline 3 & 2119,16 & 3 & 0,0049 & 0,0016 & \\
\hline \multirow[t]{2}{*}{$\mathrm{E}$} & $\operatorname{Vr}(\mathrm{l} / \mathrm{ha})$ & \multicolumn{4}{|c|}{$\mathrm{Pr}>|\mathrm{T}| \mathrm{H} 0:$ Média(i)=Média(j) } \\
\hline & & $\mathrm{i} / \mathrm{j}$ & 1 & 2 & 3 \\
\hline 1 & 262,46 & 1 & & & \\
\hline 2 & 1690,68 & 2 & 0,0001 & & \\
\hline 3 & 2918,83 & 3 & 0,0001 & 0,0001 & \\
\hline Média geral & 1623,99 & & & & \\
\hline
\end{tabular}


Tabela 27. Valores médios de volume de água retido para cada combinação população $\left(\mathrm{P}, \mathrm{pl} / \mathrm{m}^{2}\right)$ x época de avaliação (E) no experimento $\mathrm{Ll}$ e teste de comparação dos valores médios de volume de água retido entre os tratamentos $\mathbf{P} \times \mathbf{E}$.

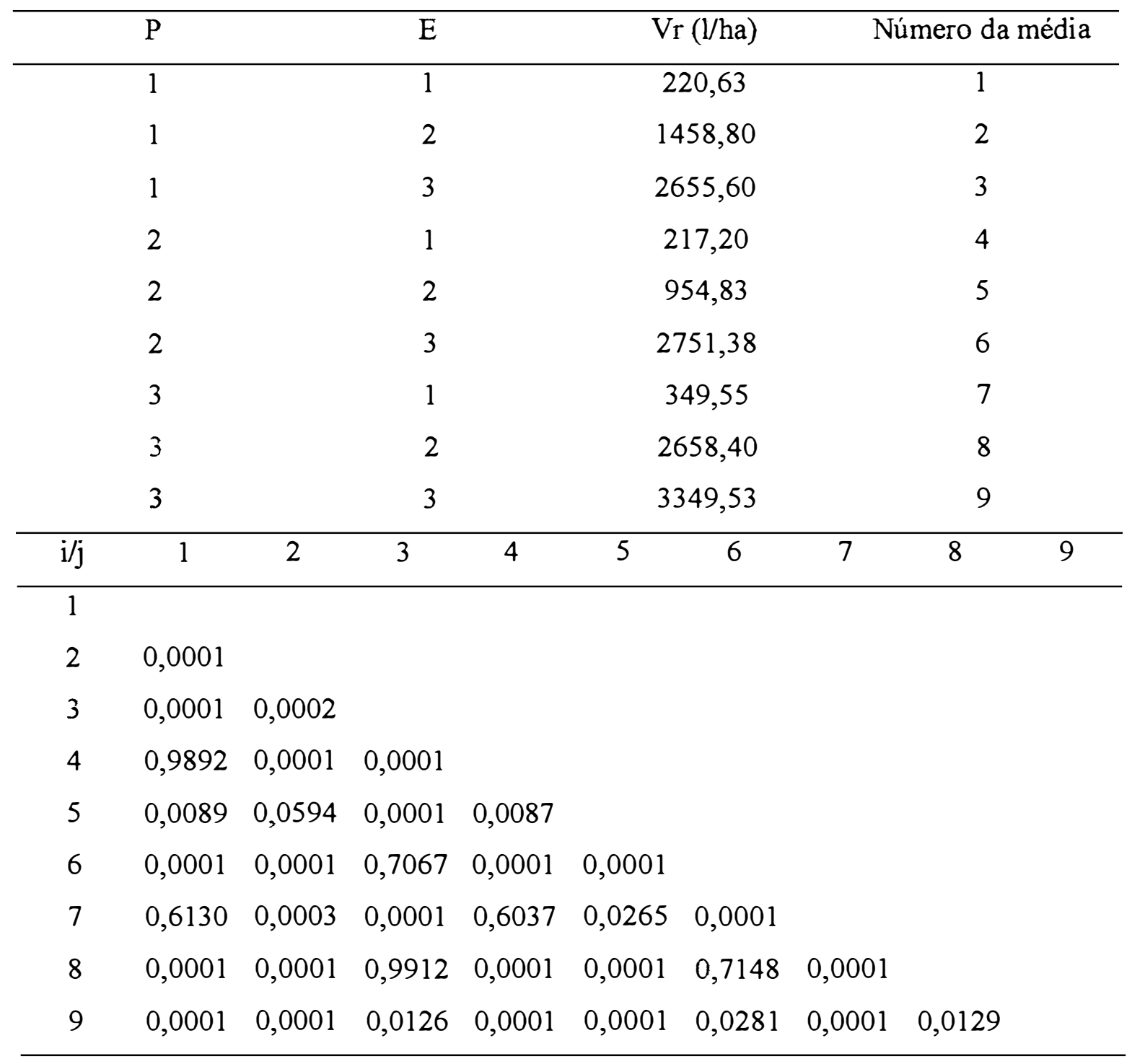


Tabela 28. Análise de variância relativa ao volume de água retido ( $\mathrm{Vr}, \mathrm{l} / \mathrm{ha}$ ) correspondente ao experimento L2 (Lâmina: $1,3 \mathrm{~mm}$ ).

\begin{tabular}{lcccc}
\hline Causa da variação & Graus de Liberdade & S.Q. & Q.M. & F \\
\hline População (P)) & 2 & 2699341,04 & 1349670,52 & $15,28^{* *}$ \\
Resíduo (a) & 9 & 794802,33 & 88311,37 & \\
(Parcelas) & 11 & & & \\
Época (E) & 2 & 45455516,06 & 22727758,03 & $227,42^{* *}$ \\
P x E & 4 & 2672427,37 & 668106,84 & $6,69 * *$ \\
Resíduo (b) & 18 & 1798882,86 & 99937,94 & \\
\hline Total & 35 & 53420969,67 & & \\
\hline
\end{tabular}

** Significativo ao nivel de $1 \%$ de probabilidade $(\alpha=0,01)$

$\mathrm{R}^{2}=0,966, \mathrm{CV}=20,53 \%, \mathrm{~s}=316,130$, média $=1.540,15$

Tabela 29. Valores médios de volume de água retido para cada população $\left(\mathrm{P}, \mathrm{pl} / \mathrm{m}^{2}\right)$ e cada época de avaliação (E) e teste de comparação dos valores médios de volume de água retido entre populações e entre épocas no experimento $\mathbf{L} 2$.

\begin{tabular}{|c|c|c|c|c|c|}
\hline \multirow[t]{2}{*}{$\mathrm{P}$} & \multirow[t]{2}{*}{$\operatorname{Vr}(\mathrm{l} / \mathrm{ha})$} & \multicolumn{4}{|c|}{$\operatorname{Pr}>|\mathrm{T}| \mathrm{H} 0:$ Média(i)=Média(j) } \\
\hline & & $i / j$ & 1 & 2 & 3 \\
\hline 1 & 1153,86 & 1 & & & \\
\hline 2 & 1709,74 & 2 & 0,0013 & & \\
\hline 3 & 1756,86 & 3 & 0,0008 & 0,7068 & \\
\hline \multirow[t]{2}{*}{$E$} & $\operatorname{Vr}(\mathrm{l} / \mathrm{ha})$ & \multicolumn{4}{|c|}{$\operatorname{Pr}>|\mathrm{T}| \mathrm{HO}:$ Média(i)=Média(j) } \\
\hline & & $\mathrm{i} / \mathrm{j}$ & 1 & 2 & 3 \\
\hline 1 & 56,33 & 1 & & & \\
\hline 2 & 1789,45 & 2 & 0,0001 & & \\
\hline 3 & 2774,68 & 3 & 0,0001 & 0,0001 & \\
\hline Média geral & 1540,15 & & & & \\
\hline
\end{tabular}


Tabela 30. Valores médios de volume de água retido para cada combinação população $\left(\mathrm{P}, \mathrm{pl} / \mathrm{m}^{2}\right)$ x época de avaliação (E) no experimento $\mathrm{L} 2$ e teste de comparação dos valores médios de volume de água retido entre os tratamentos $\mathbf{P} \times \mathbf{E}$.

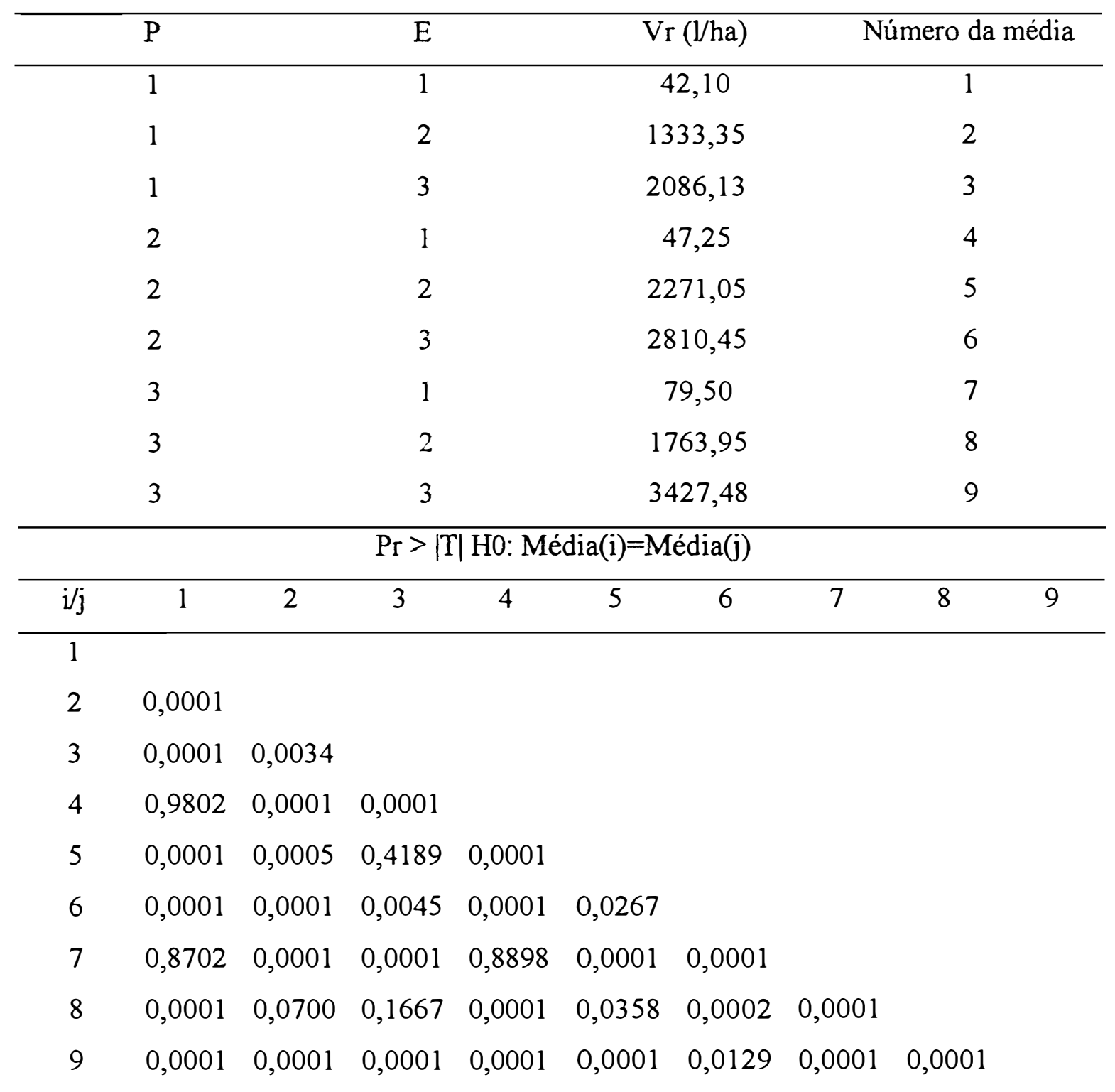


Tabela 31. Análise de variância conjunta para os experimentos L1 (Lâmina: 3,6 $\mathrm{mm}$ ) e L2 (Lâmina: $1,3 \mathrm{~mm}$ ) relativa ao volume de água retido (Vr, l/ha).

\begin{tabular}{lcrrr}
\hline Causa da variação & Graus de Liberdade & \multicolumn{1}{c}{ S.Q. } & Q.M. & \multicolumn{1}{c}{ F } \\
\hline Lâmina (L) & 1 & 126512,88 & 126512,88 & $0,88^{\text {n.s. }}$ \\
População (P) & 2 & 5086760,41 & 2543380,20 & $17,73 * *$ \\
L x P & 2 & 2139007,41 & 1069503,71 & $7,45^{* *}$ \\
Resíduo (a) & 18 & 2582613,49 & 143478,53 & \\
(Parcelas) & 23 & & & \\
Épocas (E) & 2 & 87561884,42 & 43780942,21 & $388,42^{* *}$ \\
P x E & 4 & 1995343,09 & 498835,77 & $4,43 * *$ \\
L x E & 2 & 311647,16 & 155823,58 & $1,38^{\text {n.s. }}$ \\
Ex L x P & 4 & 3454439,94 & 863609,99 & $7,66^{* *}$ \\
Resíduo (b) & 36 & 4057727,03 & 112714,64 & \\
\hline Total & 71 & 107315935,83 & & \\
\hline
\end{tabular}

** Significativo ao nivel de $1 \%$ de probabilidade $(\alpha=0,01)$

* Significativo ao nivel de $5 \%$ de probabilidade $(\alpha=0,05)$

$\mathrm{R}^{2}=0,962, \mathrm{CV}=21,22 \%, \mathrm{~s}=335,730$, média $=1.582,07$ 
Tabela 32. Valores médios de volume de água retido para população $\left(\mathrm{P}, \mathrm{pl} / \mathrm{m}^{2}\right)$, lâmina aplicada (L), lâmina x população e época de avaliação, segundo a análise conjunta dos experimentos L1 e L2; e teste de comparação dos valores médios de volume de água retido.

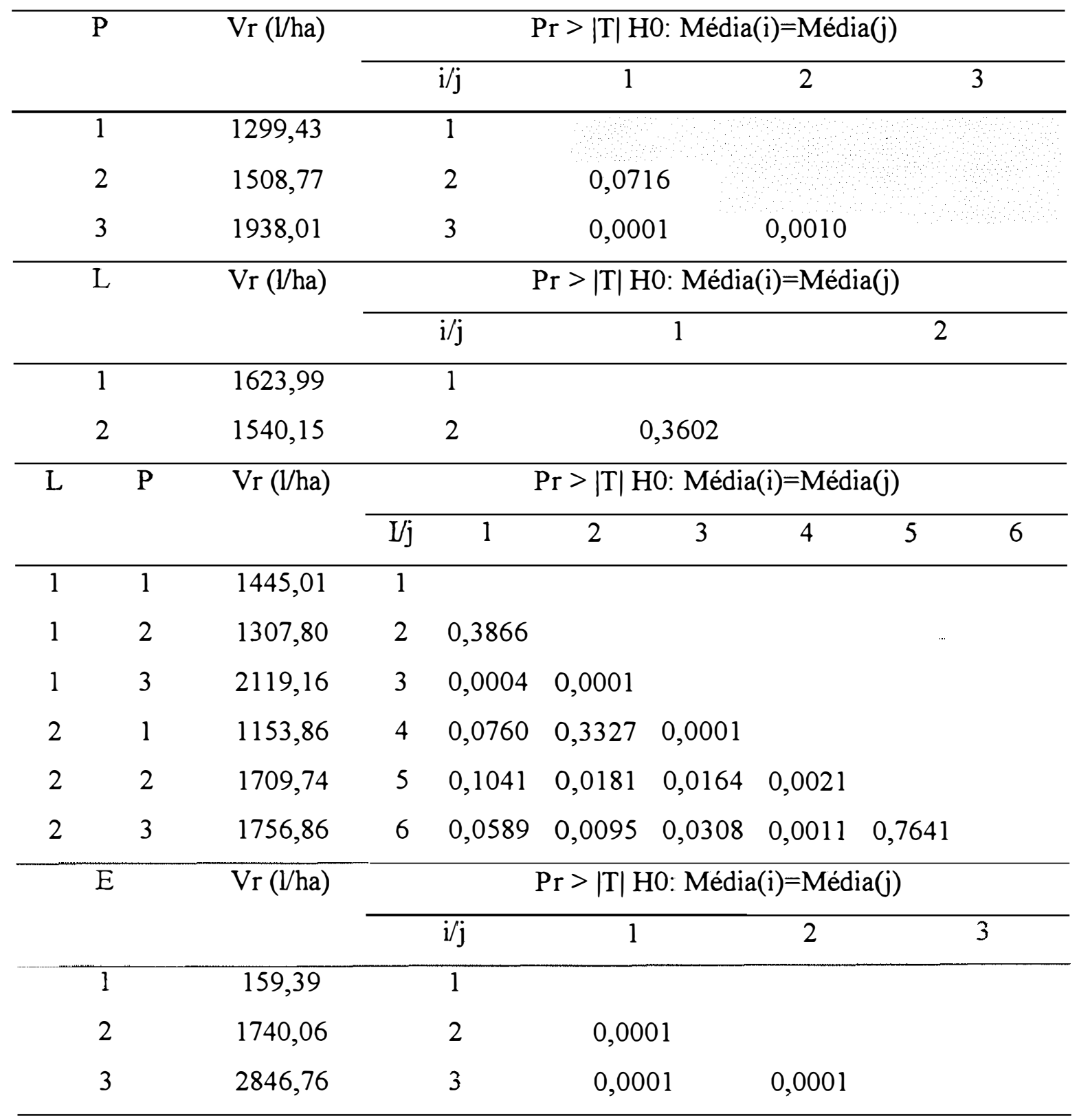


Tabela 33. Valores médios de volume de água retido para população $\left(\mathrm{P}, \mathrm{pl} / \mathrm{m}^{2}\right)$ x época de avaliação (E) e lâmina aplicada ( $\mathrm{L}, \mathrm{mm})$ x época de avaliação, segundo a análise conjunta dos experimentos L1 (3,6 $\mathrm{mm})$ e L2 (1,3 $\mathrm{mm})$ e teste de comparação dos valores médios de volume de água retido.

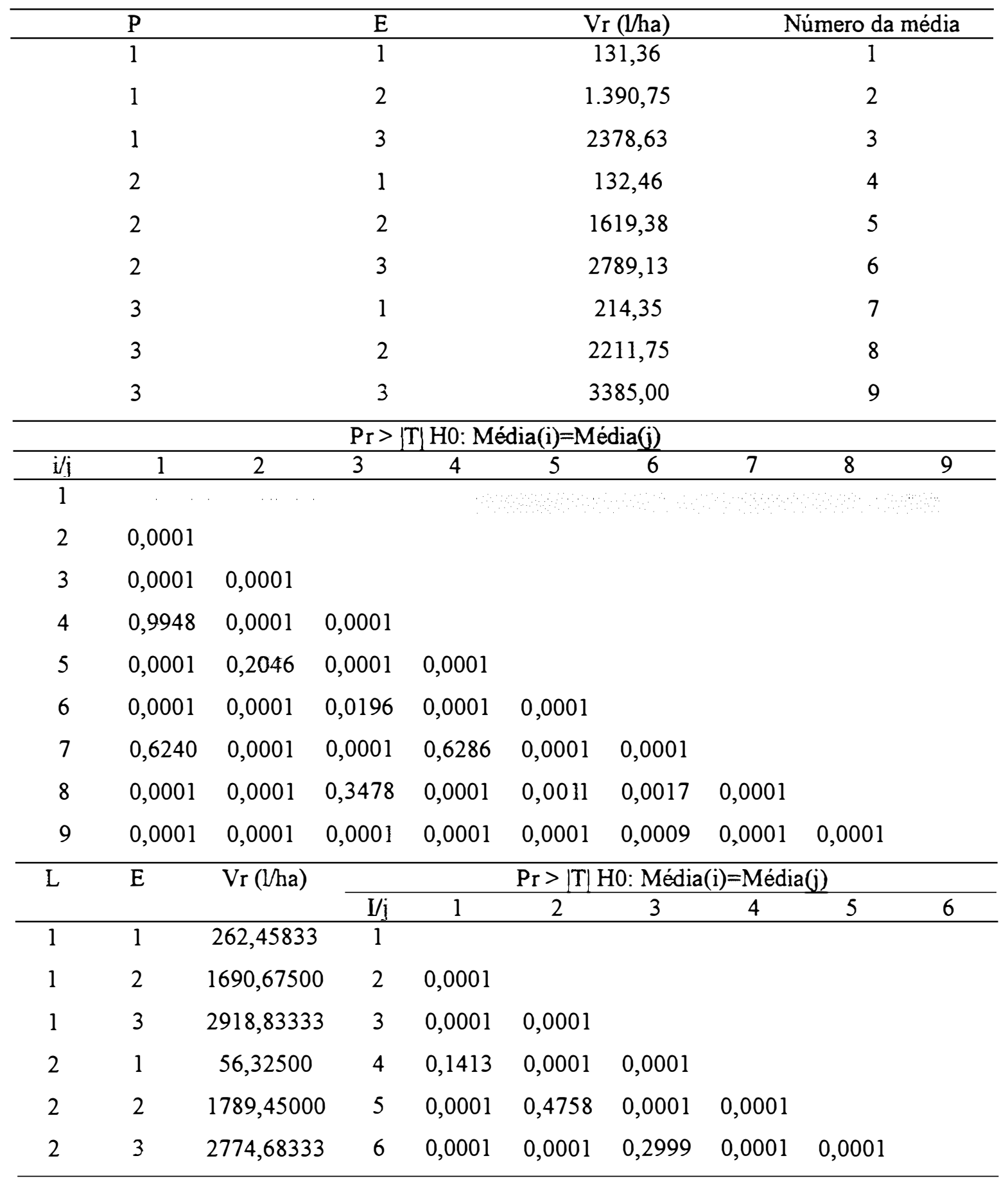




\section{REFERÊNCIAS BIBLIOGRÁFICAS}

ASSOCIAÇÃO BRASILEIRA DE NORMAS TÉCNICAS. Sistema de irrigação por aspersão pivô central - caracterização de desempenho/método de ensaio: projeto de norma 12:02.08-005. Rio de Janeiro, 1985. 9p.

BOARETTO, A.E.; ROSOLÉM, C.A. Adubação foliar: conceituação e prática. In: SIMPÓSIO BRASILEIRO DE ADUBAÇÃO FOLIAR, 2, Botucatu, 1987. p.161180.

BULL, L.T. Nutrição mineral do milho. In: Cultura do milho: fatores que afetam a produtividade. Piracicaba: POTAFOS, 1993. p.63-145.

CAMARGO, P.N. de; SILVA, O. Manual de adubação foliar. São Paulo: Herba, 1990. 256p.

CHRISTIANSEN, J.E. Irrigation by sprinkling. Berkeley: Califomia Agricultural Experiment Station, 1942. (Bulletin n 570).

COELHO, A.M. Fertigação. In: Quimigação: aplicação de produtos químicos e biológicos via irrigação. Brasilia: EMBRAPA, SPI, 1994. p.201-227.

CONTE, M. L.; LEOPOLDO, P.R. Estimativa da retenção de água de chuva pela cultura de milho. Botucatu, Engenharia Agrícola, v. 10, n. 1, p.47-55, 1986. 
DA SILVA, C.L.; RAMOS, M.M.; FERREIRA, P.A.; SEDIYAMA, G.C.; LOUREIRO, B.T. Medição e simulação da interceptação foliar da água na cultura de milho. Pesquisa Agropecuária Brasileira, v. 29, n. 11, p.1735-1741, 1994.

DOURADO NETO, D.; FANCELLI, A.L. Manejo da água na cultura de milho: aspectos teóricos fundamentais. In: FANCELLI, A.L.; DOURADO NETO, D. (Coord.) Tecnologia da produção de milho. Piracicaba, Publique, 1997. p.141-156.

EMPRESA BRASILEIRA DE PESQUISA AGROPECUÁRIA. Programa Nacional de pesquisa de milho. Brasília: EMBRAPA, DID, 1981.50 p.

FANCELLI, A.L. Plantas alimentícias: guia para aula, estudos e discussão. Piracicaba: ESALQ, Departamento de Agricultura, 1986a. 131p.

FANCELLI, A.L. Plantas Alimentícias: guia para aula, estudos e discussão. Centro Acadêmico "Luiz de Queiroz"- ESALQ-USP. 1986b. 131p.

FANCELLI, A.L. Tecnologia da produção do milho para alta produtividade. Piracicaba: ESALQ, Departamento de Agricultura, 1994. 223p.

FANCELLI, A.L.; DOURADO-NETO, D. Milho irrigado: considerações gerais para manejo. Piracicaba: ESALQ, Departamento de Agricultura, 1992. 5p.

FANCELLI, A.L.; LIMA, U.A. Milho: Produção, pré-processamento e transformação agroindustrial. Piracicaba: FEALQ, s.d., 112p. (Série Extensão Agroindustrial, 5).

FOLEGATTI, M.V. Irrigação. In: FANCELLI, A.L.; FOLEGATTI, M.V., (Ed.) Sistema de produção para milho e feijão irrigados. Piracicaba: ESALQ, Departamento de Agricultura; Departamento de Engenharia Rural, 1994. p.1. 
FOLEGATTI, M.V.; PAZ, V.P.; MUNDIN, P.M. Intercepção foliar da lâmina de irrigação na cultura do milho sob aspersão convencional. In: CONGRESSO BRASILEIRO DE ENGENHARIA AGRÍCOLA, 27, Poços de Calda, 1998. Poços de Calda: SBEA, 1998. Anais. v.2, p.19-21.

GIRARDIN, P. The "funnel effect" of a maize cannopy. In: EUROPEAN SOCIETY FOR AGRONOMY CONGRESS, 2, Warwick, 1992. Proccedings. Colmar: ESA, 1992. p.76-77.

GOODMANN, M.M;; SMITH, J.S.C. Botânica do milho. In: Melhoramento e produção do milho no Brasil. Piracicaba: Fundação Cargill, 1978. p.32-70.

JUNQUEIRA NETTO, A. Fungigação. In: FANCELLI, A.L. (coord.). A CULTURA DO FEIJÃO IRRIGADO. Piracicaba: ESALQ, Departamento de Agricultura, 1990. p. $105-113$.

LEON NEW, L.I. Introduction: Why chemigate? In: Chemigation. workbook. Texas, Agriculture Extension Service, 1990. p. I-1.

LEOPOLDO, P.R. Aspectos hidrológicos de Floresta Amazônica densa na região de Manaus. Botucatu, 1981. 111p., Tese (Livre Docência)-Universidade Estadual Paulista "Julho de Mesquita Filho".

LEOPOLDO, P.R.; SOUSA, A.P.; TUACEK FILHO, S. Intercepção da água de chuva em cultura de cana-de-açúcar. Brasil Açucareiro, v. 98, n. 6, p.9-16, 1981.

LIMA, W.P. Interceptação da chuva em povoamentos de eucalipto e pinheiro. IPEF, v. 13, p. 75-90, 1976. 
LINSLEY, R.K.; KOHLER, M.A.; PAULHUS, J.L.H. Applied hydrology. New York, McGraw-Hill, 1949. 689p.

McMASTER, G.M.; DOUGLAS, D.R. Fungicide application through sprinkler irrigation system. Transations of the ASAE, v. 19, n. 2, p. 1041-1044, 1976.

MIRANDA, R.A.C.; BUTLER, D.R. Interception of rainfall in a hedgerow apple orchard. Journal of Hidrology, v. 87, p.245-253, 1986.

MUNDIM, P.M. Uniformidade de distribuição de água por aspersão convencional na presença da cultura do milho. Piracicaba, 1996. 82p. Dissertação (Mestrado)-Escola Superior de Agricultura "Luiz de Queiroz", Universidade de São Paulo.

PURSEGLOVE, J.W. Tropical crops. monocotyledons I. New York, John Wiley, 1972. $334 \mathrm{p}$.

RAO, A.S. Interception losses of rainfall from cashew trees. Journal of Hidrology, v.90, p.293-301, 1987.

RESENDE, M.; ALVES, V.M.C.; FRANÇA, G.E.; MONTEIRO, J.A. Manejo de irrigação e fertilizantes na cultura do milho. Informe Agropecuário, v. 14, n. 164, p.26-34, 1990.

RESENDE, M.; FRANÇA, G.E.; ALVES, V.A.C. Cultura do milho irrigado. In: Cultura de milho: FATORES QUE AFETAM A PRODUTIVIDADE. Piracicaba: POTAFOS, 1993. p.238-248.

STEINER, J.L.; KANEMASU, E. T.; CLARK, R.N. Spray losses and partitioning of water under a center pivot sprinkler system. Transations of the ASAE, v. 26, n. 4, p.1128-1134, 1983 
STONE, K.C.; STANSELL, J.R.; YOUNG, J.R. Insecticide distribution through an irrigated corn canopy. Transations of the ASAE, v. 37, n. 1, p.135-138, 1994.

THREADGILL, E.D. Chemigation via sprinkler irrigation: current status and future development. Applied Engineering in Agriculture. v. 1, n. 1, p.16-23, 1985.

VIANA, P.A Insetigação. In: Quimigação: aplicação de produtos químicos e biológicos via irrigação. Brasília: EMBRAPA, SPI, 1994. p.249-268.

VICTÓRIA FILHO, R. Controle de plantas daninhas na cultura de feijão (Phaseolus vulgaris). In: FANCELLI, A.L. (Coord.). A CULTURA DO FEIJÃO IRRIGADO. Piracicaba: ESALQ, Departamento de Agricultura, 1990. p.95-103.

VIEIRA, R.F. Introdução à quimigação. In: Quimigação: aplicação de produtos químicos e biológicos via irrigação. Brasília: EMBRAPA, SPI, 1994. p.13-40. 
APÊNDICE: Valores observados e estimados de índice de área foliar (IAF, $\left.\mathrm{m}^{2} / \mathrm{m}^{2}\right)$, lâmina de água retida $(\mathrm{h}, \mathrm{mm})$ e volume máximo retido de água $(\mathrm{Vr}, \mathrm{l} / \mathrm{ha})$ pelos diferentes modelos

Tabela 34. Valores observados (IAFo, $\mathrm{m}^{2} / \mathrm{m}^{2}$ ) e estimados (IAFe, $\mathrm{m}^{2} / \mathrm{m}^{2}$ ) do índice de área foliar em função do desenvolvimento relativo (Dr) e da população de plantas $\left(\mathrm{P}, \mathrm{pl} / \mathrm{m}^{2}\right)$, desvio (d) entre os valores observados e estimados, erro relativo ( $\mathrm{Er}, \%$ ), e limites inferior (LIic) e superior (LSic) do intervalo de confiança ao nível de $\mathbf{9 5 \%}$ de probabilidade.

\begin{tabular}{crcrccccc}
\hline Id & Dr & P & IAFo & IAFe & d & Er, \% & $95 \%$, LIic & $95 \%$, LSic \\
\hline 1 & 0 & 4,1176 & 0 & 0,000394 & $-0,00039$ & - & $-0,42413$ & 0,424915 \\
2 & 0 & 5,2941 & 0 & 0,000935 & $-0,00093$ & - & $-0,32195$ & 0,323822 \\
3 & 0 & 6,4706 & 0 & 0,001471 & $-0,00147$ & - & $-0,45358$ & 0,456521 \\
4 & 0,205 & 4,1176 & 0,42 & 0,433932 & $-0,01393$ & $-3,31717$ & 0,04348 & 0,824384 \\
5 & 0,205 & 5,2941 & 0,50 & 0,51196 & $-0,01196$ & $-2,39202$ & 0,18584 & 0,83808 \\
6 & 0,205 & 6,4706 & 0,61 & 0,589332 & 0,020668 & 3,38821 & 0,154769 & 1,023895 \\
7 & 0,325 & 4,1176 & 2,25 & 2,370091 & $-0,12009$ & $-5,33739$ & 1,976028 & 2,764154 \\
8 & 0,325 & 5,2941 & 3,12 & 2,794175 & 0,325825 & 10,44312 & 2,378827 & 3,209522 \\
9 & 0,325 & 6,4706 & 3,02 & 3,214692 & $-0,19469$ & $-6,44675$ & 2,771376 & 3,658008 \\
10 & 0,465 & 4,1176 & 3,46 & 3,373907 & 0,086093 & 2,488233 & 2,88571 & 3,862104 \\
11 & 0,465 & 5,2941 & 3,75 & 3,977406 & $-0,22741$ & $-6,06415$ & 3,484109 & 4,470703 \\
12 & 0,465 & 6,4706 & 4,71 & 4,575829 & 0,134171 & 2,848642 & 4,068079 & 5,083579 \\
\hline
\end{tabular}


Tabela 35. Valores observados (ho, $\mathrm{mm}$ ) e estimados (he, $\mathrm{mm}$ ) da lâmina de água retida em função do índice de área foliar (LAF, $\mathrm{m}^{2} / \mathrm{m}^{2}$ ), desvio (d) entre os valores observados e estimados, erro relativo (Er, \%), e limites inferior (LIic) e superior (LSic) do intervalo de confiança ao nível de $\mathbf{9 5 \%}$ de probabilidade.

\begin{tabular}{|c|c|c|c|c|c|c|c|}
\hline$\overline{I d}$ & IAF & ho & he & $d$ & $\mathrm{Er}, \%$ & $95 \%$, LIic & $95 \%$, LSic \\
\hline 1 & 0,365 & 0,06 & 0,024741 & 0,035259 & 58,76471 & 0,012378 & 0,037104 \\
\hline 2 & 0,478 & 0,009 & 0,030497 & $-0,0215$ & $-238,857$ & 0,016434 & 0,04456 \\
\hline 3 & 0,493 & 0,045 & 0,031206 & 0,013794 & 30,65395 & 0,016971 & 0,045441 \\
\hline 4 & 0,5 & 0,01 & 0,031532 & $-0,02153$ & $-215,322$ & 0,01722 & 0,045844 \\
\hline 5 & 0,59 & 0,014 & 0,0355 & $-0,0215$ & $-153,573$ & 0,020407 & 0,050594 \\
\hline 6 & 0,633 & 0,055 & 0,037254 & 0,017746 & 32,26562 & 0,021907 & 0,052601 \\
\hline 7 & 2,045 & 0,072 & 0,064773 & 0,007227 & 10,03703 & 0,054234 & 0,075312 \\
\hline 8 & 2,45 & 0,054 & 0,067244 & $-0,01324$ & $-24,5259$ & 0,057161 & 0,077327 \\
\hline 9 & 2,5 & 0,039 & 0,067476 & $-0,02848$ & $-73,0147$ & 0,057387 & 0,077565 \\
\hline 10 & 2,87 & 0,092 & 0,068828 & 0,023172 & 25,1866 & 0,0 & 0,07922 \\
\hline 11 & 3,17 & 0,056 & 0,069568 & $-0,01357$ & $-24,2289$ & 0,058752 & 0,080384 \\
\hline 12 & 3,31 & 0,062 & 0,069834 & $-0,00783$ & $-12,6359$ & 0,058806 & 0,080863 \\
\hline 13 & 3,43 & 0,081 & 0,07003 & 0,01097 & 13,54308 & 0,058821 & 0,081239 \\
\hline 14 & 3,6 & 0,074 & 0,070265 & 0,003735 & 5,047847 & 0,058809 & 0,081721 \\
\hline 15 & 3,74 & 0,061 & 0,070426 & $-0,00943$ & $-15,4519$ & 0,058778 & 0,082073 \\
\hline 16 & 4,08 & 0,069 & 0,070723 & $-0,00172$ & $-2,49695$ & 0,058665 & 0,082781 \\
\hline 17 & 4,62 & 0,073 & 0,071008 & 0,001992 & 2,728465 & 0,058465 & 0,083552 \\
\hline 18 & 4,802 & 0,072 & 0,07107 & 0,00093 & 1,291097 & 0,058404 & 0,083737 \\
\hline
\end{tabular}


Tabela 36. Valores observados (Vro, mm) e estimados (Vre, Vha) de volume de água retida em função do índice de área foliar (IAF, $\mathrm{m}^{2} / \mathrm{m}^{2}$ ), desvio (d) entre os valores observados e estimados, erro relativo (Er, \%), e limites inferior (LIic) e superior (LSic) do intervalo de confiança ao nível de 95\% de probabilidade.

\begin{tabular}{|c|c|c|c|c|c|c|c|}
\hline Id & IAF & Vro & Vre & $\mathrm{d}$ & $\mathrm{Er}, \%$ & $95 \%$, LIic & $95 \%$, LSic \\
\hline 1 & 0,37 & 220,63 & 244,1514 & $-23,5214$ & $-10,661$ & 220,7839 & 267,5189 \\
\hline 2 & 0,48 & 42,01 & 316,7369 & $-274,727$ & $-653,956$ & 286,4223 & 347,0516 \\
\hline 3 & 0,49 & 217,2 & 323,3356 & $-106,136$ & $-48,8654$ & 292,3894 & 354,2818 \\
\hline 4 & 0,5 & 47,73 & 329,9343 & $-282,204$ & $-591,251$ & 298,3566 & 361,5121 \\
\hline 5 & 0,59 & 79,15 & 389,3225 & $-310,172$ & $-391,879$ & 352,0607 & 426,5842 \\
\hline 6 & 0,63 & 349,55 & 415,7172 & $-66,1672$ & $-18,9293$ & 375,9293 & 455,5052 \\
\hline 7 & 2,05 & 1458,8 & 1352,731 & 106,0694 & 7,271001 & 1223,262 & 1482,199 \\
\hline 8 & 2,45 & 1333,35 & 1616,678 & $-283,328$ & $-21,2493$ & 1461,947 & 1771,409 \\
\hline 9 & 2,51 & 954,83 & 1656,27 & $-701,44$ & $-73,4623$ & 1497,75 & 1814,79 \\
\hline 10 & 2,87 & 2658,4 & 1893,823 & 764,5771 & 28,7608 & 1712,567 & 2075,079 \\
\hline 11 & 3,17 & 1763,95 & 2091,783 & $-327,833$ & $-18,5852$ & 1891,581 & 2291,986 \\
\hline 12 & 3,31 & 2086,13 & 2184,165 & $-98,0351$ & $-4,69938$ & 1975,12 & 2393,21 \\
\hline 13 & 3,43 & 2751,38 & 2263,349 & 488,0307 & 17,73767 & 2046,726 & 2479,973 \\
\hline 14 & 3,6 & 2655,6 & 2375,527 & 280,073 & 10,54651 & 2148,167 & 2602,887 \\
\hline 15 & 3,74 & 2271,1 & 2467,909 & $-196,809$ & $-8,66578$ & 2231,707 & 2704,11 \\
\hline 16 & 4,08 & 2810,45 & 2692,264 & 118,1861 & 4,205237 & 2434,59 & 2949,938 \\
\hline 17 & 4,62 & 3349,53 & 3048,593 & 300,937 & 8,984456 & 2756,815 & 3340,371 \\
\hline 18 & 4,8 & 3427,48 & 3167,369 & 260,1107 & 7,588978 & 2864,223 & 3470,516 \\
\hline
\end{tabular}


Tabela 37. Valores observados $\left(\right.$ Vro, $\left.\mathrm{m}^{2} / \mathrm{m}^{2}\right)$ e estimados $\left(\mathrm{Vre}, \mathrm{m}^{2} / \mathrm{m}^{2}\right)$ de volume de água retida em função do desenvolvimento relativo (Dr) e da população de plantas $\left(\mathrm{P}, \mathrm{pl} / \mathrm{m}^{2}\right)$, desvio (d) entre os valores observados e estimados, erro relativo (Er, \%), e limites inferior (LIic) e superior (LSic) do intervalo de confiança ao nível de $95 \%$ de probabilidade.

\begin{tabular}{rrrrrcccr}
\hline Id & Dr & \multicolumn{1}{c}{ P } & \multicolumn{1}{c}{ Vro } & Vre & d & Er, \% & $95 \%$, Llic & $95 \%$, LSic \\
\hline 1 & 0 & 4,1176 & 0 & 0,748898 & $-0,7489$ & - & $-155,457$ & 156,9548 \\
2 & 0 & 5,2941 & 0 & 7,339434 & $-7,33943$ & - & $-122,896$ & 137,5745 \\
3 & 0 & 6,4706 & 0 & 20,39378 & $-20,3938$ & - & $-170,36$ & 211,1473 \\
4 & 0,205 & 4,1176 & 145,77 & 127,8068 & 17,96323 & 12,32299 & $-23,5037$ & 279,1172 \\
5 & 0,205 & 5,2941 & 134,74 & 153,8787 & $-19,1387$ & $-14,2042$ & 23,91617 & 283,8413 \\
6 & 0,205 & 6,4706 & 208,34 & 205,5213 & 2,818691 & 1,352929 & 18,51166 & 392,531 \\
7 & 0,325 & 4,1176 & 1415,99 & 1440,508 & $-24,518$ & $-1,73151$ & 1287,608 & 1593,408 \\
8 & 0,325 & 5,2941 & 1548,68 & 1667,853 & $-119,173$ & $-7,69512$ & 1508,252 & 1827,453 \\
9 & 0,325 & 6,4706 & 2229,36 & 2118,171 & 111,1895 & 4,987507 & 1937,106 & 2299,235 \\
10 & 0,465 & 4,1176 & 2378,8 & 2365,979 & 12,82083 & 0,538962 & 2162,767 & 2569,191 \\
11 & 0,465 & 5,2941 & 2810,54 & 2735,224 & 75,31623 & 2,679778 & 2530,942 & 2939,506 \\
12 & 0,465 & 6,4706 & 3398,24 & 3466,613 & $-68,3727$ & $-2,012$ & 3254,816 & 3678,409 \\
\hline
\end{tabular}

